In cooperation with Fort Peck Tribes Office of Environmental Protection

\title{
Delineation of Brine Contamination in and near the East Poplar Oil Field, Fort Peck Indian Reservation, Northeastern Montana, 2004-09
}

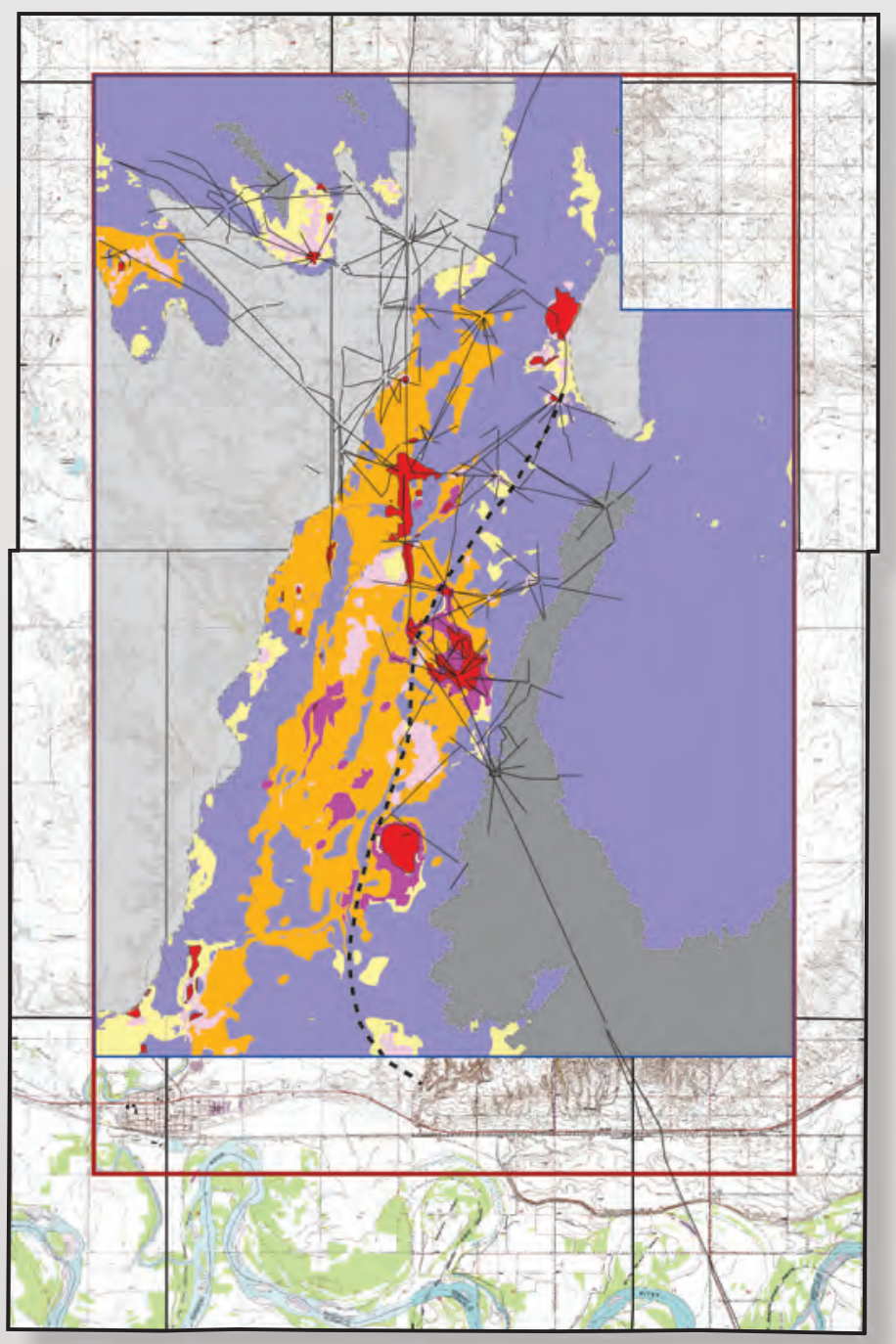

Scientific Investigations Report 2014-5024 



\section{Delineation of Brine Contamination in and near the East Poplar Oil Field, Fort Peck Indian Reservation, Northeastern Montana, 2004-09}

By Joanna N. Thamke and Bruce D. Smith

Prepared in cooperation with the Fort Peck Tribes Office of Environmental

Protection

Scientific Investigations Report 2014-5024 


\title{
U.S. Department of the Interior \\ SALLY JEWELL, Secretary
}

\section{U.S. Geological Survey \\ Suzette M. Kimball, Acting Director}

\section{U.S. Geological Survey, Reston, Virginia: 2014}

\author{
For more information on the USGS — the Federal source for science about the Earth, its natural and living \\ resources, natural hazards, and the environment, visit http://www.usgs.gov or call 1-888-ASK-USGS. \\ For an overview of USGS information products, including maps, imagery, and publications, \\ visit http://www.usgs.gov/pubprod \\ To order this and other USGS information products, visit http://store.usgs.gov
}

Any use of trade, firm, or product names is for descriptive purposes only and does not imply endorsement by the U.S. Government.

Although this information product, for the most part, is in the public domain, it also may contain copyrighted materials as noted in the text. Permission to reproduce copyrighted items must be secured from the copyright owner.

Suggested citation:

Thamke, J.N., and Smith, B.D., 2014, Delineation of brine contamination in and near the East Poplar oil field, Fort Peck Indian Reservation, northeastern Montana, 2004-09: U.S. Geological Survey Scientific Investigations Report 2014-5024, 40 p., http://dx.doi.org/10.3133/sir20145024.

ISSN 2328-0328 (online) 


\section{Acknowledgments}

The Fort Peck Tribes are acknowledged for their support throughout this and previous investigations; particular recognition is extended to Debi Madison and Christa Tyrrell, who were extensively involved with the planning of this project, provided field assistance, and maintained clear communication among the many entities working in the study area through a Technical Advisory Committee. Appreciation is given to Atkins, Fort Peck Tribes Office of Environmental Protection, Dowl HKM, HydroSolutions, Inc., Murphy Oil Corporation, Pioneer Natural Resources USA, Inc., and U.S. Environmental Protection Agency for providing water-quality data through 2009 for sampled wells in and near the East Poplar oil field. Ballard Petroleum and Murphy Oil Corporation supplied maps of oil-related facilities in parts of the East Poplar oil field. Appreciation is extended to the Bureau of Indian Affairs for compiling right-of-way requests for oil pipelines in the study area. NEMONT Telephone Cooperative, Inc. supplied a map of telephone lines in the study area. Many thanks are extended to the well owners in the study area who allowed access to their wells for sample collection.

Particular appreciation is given to USGS employees for their geospatial assistance to develop maps and calculations in this report: DeAnn M. Dutton for her skills in grid-to-map conversion, illustration preparation, and lateral extent calculations; and T. Roy Sando for his ability to determine volumetric calculations using multiple grids. 



\section{Contents}

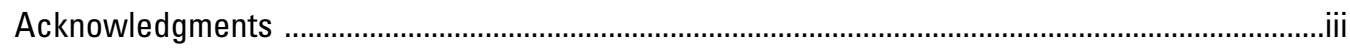

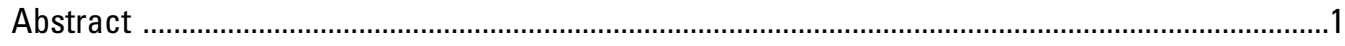

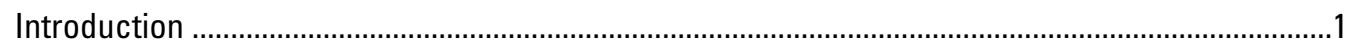

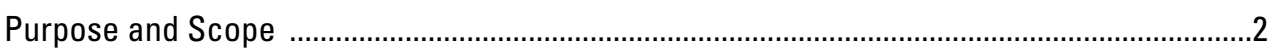

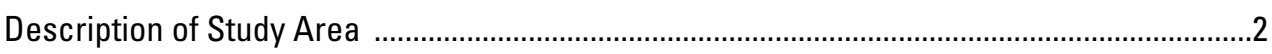

Site Identification and Well-Naming Systems ................................................................. 2

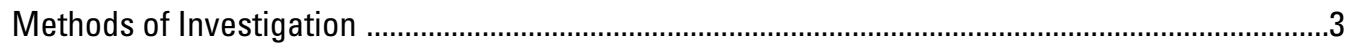

Historical Oil-Related Features ..........................................................................................

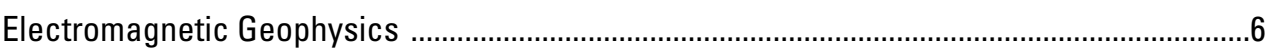

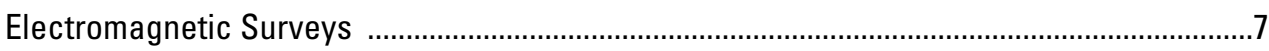

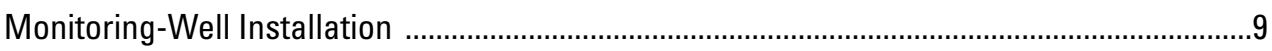

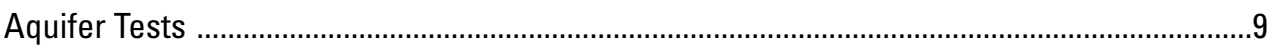

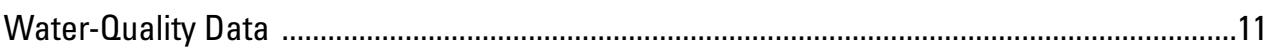

Altitude and Configuration of Top of Shallow Aquifers ......................................................11

Altitude and Configuration of Top of Upper Cretaceous Bearpaw Shale ..............................13

General Hydrogeology of Shallow Aquifers ..........................................................................

Groundwater Occurrence and Movement ........................................................................13

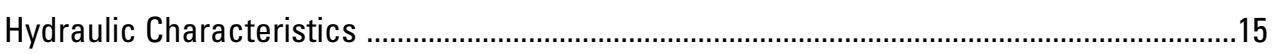

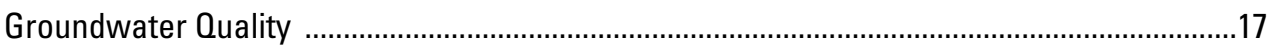

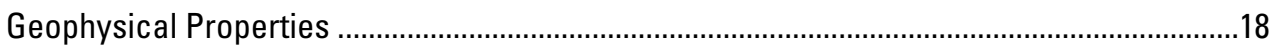

Geospatial Distribution of Apparent Conductivity .........................................................18

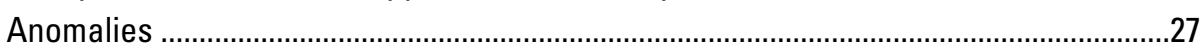

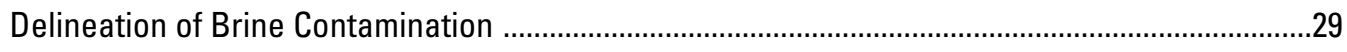

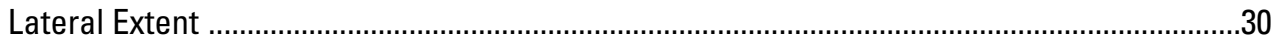

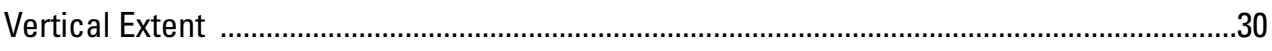

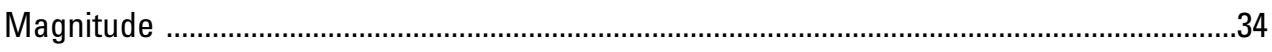

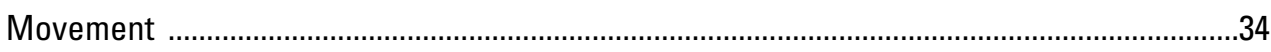

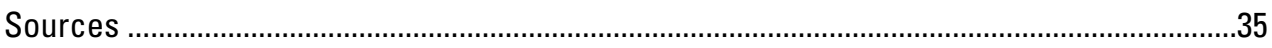

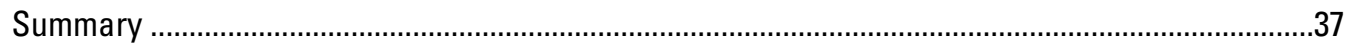

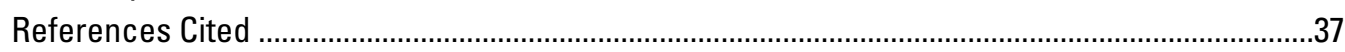

Appendixes (digital downloads)

1. Ground electromagnetic measurements in and near the East Poplar oil field, 2005

2. Lithologic logs and completion details for U.S. Geological Survey and Fort Peck Tribes Office of Environmental Protection monitoring wells drilled in and near the East Poplar oil field, 2006 and 2009

3. Data from aquifer test conducted in Quaternary alluvium in the East Poplar oil field, March 27, 2007

4. Data from aquifer tests conducted in Quaternary Wiota Gravel in the East Poplar oil field, March 29-30 and June 26-27, 2007

5. Physical and chemical characteristics of water samples collected from privately owned wells, monitoring wells, oil wells, and brine-injection wells in and near the East Poplar oil field, 1952-2009

6. Physical and chemical characteristics of rinsate water after field cleaning of U.S. Geological Survey sampling equipment before and during water-sample collection from wells in and near the East Poplar oil field, September 2003 and March 2007 
7. Concentration of selected fuel ethers, petroleum compounds, and radionuclides in water samples collected from selected monitoring wells and in rinsate water after cleaning of sampling equipment in and near the East Poplar oil field, March 2007

8. Estimating rates of water drainage through the unsaturated zone at the East Poplar oil field on the basis of concentration profiles of chloride and nitrate, 2006 by Richard W. Healy, Branch of Regional Research, Central Region, U.S. Geological Survey

9. Sample depth, water content by weight, and chloride and nitrate concentrations in water and sediment extracts in and near the East Poplar oil field, August 2006

10. Average chloride and nitrate in soil water and drainage rates for 11 sites in and near the East Poplar oil field, August 2006

\section{Figures}

1. Map showing location of study area

2. Diagram showing site-numbering system

3. Map showing oil-related features in and near the East Poplar oil field, 1952-2004 ........5

4. Map showing locations of electromagnetic data collected in and near the East Poplar oil field

5. Map showing locations of selected wells in and near the East Poplar oil field .............10

6. Map showing approximate altitude and configuration of the top of the shallow aquifers in and near the East Poplar oil field

7. Map showing approximate altitude and configuration of the top of the Upper Cretaceous Bearpaw Shale in and near the East Poplar oil field

8. Maps showing altitude difference between the differential depth at selected electromagnetic frequencies and the top of the Bearpaw Shale, in and near the East Poplar oil field, 2004

9. Generalized diagram showing the relevant range of differential depth, in and near the East Poplar oil field, 2004

10. Map showing apparent conductivity measured with the differential depth in the relevant range of the shallow aquifers, in and near the East Poplar oil field, 2004 ........21

11. Map showing six geologic subareas for apparent conductivity delineation $\ldots . .23$

12. Map delineating areas of low, moderate, and high apparent conductivity in shallow aquifers, 2004, and types of water from wells in and near the East Poplar oil field

13. Borehole electromagnetic logs and airborne electromagnetic measurements at selected sites from $A$, terrace 1 ; and $B$ and $C$, terrace 3

14. Map delineating possible and confirmed areas of brine contamination in shallow aquifers, known pipelines, and types of water in shallow aquifers, in and near the East Poplar oil field study area, 2004-09

15. Conductivity depth sections using differential and inversion methods for flight lines L10390 and T19020, in and near the East Poplar oil field, 2004

16. Possible and confirmed areas of brine contamination in shallow aquifers, known pipelines, and probable source areas, 2000-09, in and near the East Poplar oil field 


\section{Tables}

1. Sources of aerial photographs and additional information used to identify various oil-related features in and near the East Poplar oil field .6

2. Mean, minimum, and maximum differential depth at five frequencies measured with airborne electromagnetic horizontal coplanar coils, East Poplar oil field, 2004 .....7

3. Hydraulic characteristics of shallow aquifers in and near the East Poplar oil field, 1985-2007

4. Characteristics of water types in selected wells completed in and near the East Poplar oil field, 1952-2009

5. General characteristics of six geologic subareas in and near the East Poplar oil field

6. Range of values used to delineate areas of low, moderate, and high apparent conductivity in and near the East Poplar oil field, 2004

\section{Conversion Factors}

Inch/Pound to SI

\begin{tabular}{|c|c|c|}
\hline Multiply & By & To obtain \\
\hline \multicolumn{3}{|c|}{ Length } \\
\hline foot (ft) & 0.3048 & meter $(\mathrm{m})$ \\
\hline mile (mi) & 1.609 & kilometer (km) \\
\hline \multicolumn{3}{|c|}{ Area } \\
\hline acre & 4,047 & square meter $\left(\mathrm{m}^{2}\right)$ \\
\hline acre & 0.004047 & square kilometer $\left(\mathrm{km}^{2}\right)$ \\
\hline square foot $\left(\mathrm{ft}^{2}\right)$ & 929.0 & square centimeter $\left(\mathrm{cm}^{2}\right)$ \\
\hline square mile $\left(\mathrm{mi}^{2}\right)$ & 2.590 & square kilometer $\left(\mathrm{km}^{2}\right)$ \\
\hline \multicolumn{3}{|c|}{ Volume } \\
\hline $\begin{array}{l}\text { barrel (bbl), (petroleum, } \\
1 \text { barrel=42 gal) }\end{array}$ & 0.1590 & cubic meter $\left(\mathrm{m}^{3}\right)$ \\
\hline gallon (gal) & 3.785 & liter (L) \\
\hline cubic inch $\left(\mathrm{in}^{3}\right)$ & 0.01639 & liter (L) \\
\hline cubic foot $\left(\mathrm{ft}^{3}\right)$ & 0.02832 & cubic meter $\left(\mathrm{m}^{3}\right)$ \\
\hline \multicolumn{3}{|c|}{ Flow rate } \\
\hline foot per day (ft/d) & 0.3048 & meter per day $(\mathrm{m} / \mathrm{d})$ \\
\hline gallon per minute (gal/min) & 0.06309 & liter per second $(\mathrm{L} / \mathrm{s})$ \\
\hline \multicolumn{3}{|c|}{ Mass } \\
\hline ounce, avoirdupois (oz) & 28.35 & gram $(\mathrm{g})$ \\
\hline \multicolumn{3}{|c|}{ Transmissivity* } \\
\hline foot squared per day $\left(\mathrm{ft}^{2} / \mathrm{d}\right)$ & 0.09290 & meter squared per day $\left(\mathrm{m}^{2} / \mathrm{d}\right.$ \\
\hline
\end{tabular}

Temperature in degrees Celsius $\left({ }^{\circ} \mathrm{C}\right)$ may be converted to degrees Fahrenheit $\left({ }^{\circ} \mathrm{F}\right)$ as follows:

${ }^{\circ} \mathrm{F}=\left(1.8 x^{\circ} \mathrm{C}\right)+32$ 
Vertical coordinate information is referenced to the National Geodetic Vertical Datum of 1929 (NGVD 29). Horizontal coordinate information is referenced to the North American Datum of 1927 (NAD 27).

Altitude, as used in this report, refers to distance above the vertical datum.

*Transmissivity: The standard unit for transmissivity is cubic foot per day per square foot times foot of aquifer thickness $\left[\left(\mathrm{ft}^{3} / \mathrm{d}\right) / \mathrm{ft}^{2}\right] \mathrm{ft}$. In this report, the mathematically reduced form, foot squared per day $\left(\mathrm{ft}^{2} / \mathrm{d}\right)$, is used for convenience.

Specific conductance is given in microsiemens per centimeter at 25 degrees Celsius $(\mu \mathrm{S} / \mathrm{cm}$ at $\left.25^{\circ} \mathrm{C}\right)$.

Concentrations of chemical constituents in water are given either in milligrams per liter (mg/L) or micrograms per liter ( $\mu \mathrm{g} / \mathrm{L})$.

\section{Abbreviations}

FPOEP Fort Peck Tribes Office of Environmental Protection

GIS Geographic information system

HKM Hurlbut, Kersich, McCullough Engineering, currently (2014) Dowl HKM

HSI HydroSolutions, Inc.

IHS Indian Health Service

LAW Land and Water Consulting, Inc., currently (2014) Atkins

MBMG Montana Bureau of Mines and Geology

MBOGC Montana Board of Oil and Gas Conservation

MDEO Montana Department of Environmental Quality

MOC Murphy Oil Corporation

MSCA Montana Salinity Control Association

MSE MSE-HKM, Inc., currently (2014) Dowl HKM

PBS\&J Post Buckley Schuh \& Jernigan, Inc., currently (2014) Atkins

PNR Pioneer Natural Resources USA, Inc.

PVC Polyvinyl chloride

RMS Root mean square

USEPA U.S. Environmental Protection Agency

USGS U.S. Geological Survey 


\title{
Delineation of Brine Contamination in and near the East Poplar Oil Field, Fort Peck Indian Reservation, Northeastern Montana, 2004-09
}

\author{
By Joanna N. Thamke and Bruce D. Smith
}

\section{Abstract}

The extent of brine contamination in the shallow aquifers in and near the East Poplar oil field is as much as 17.9 square miles and appears to be present throughout the entire saturated zone in contaminated areas. The brine contamination affects 15-37 billion gallons of groundwater. Brine contamination in the shallow aquifers east of the Poplar River generally moves to the southwest toward the river and then southward in the Poplar River valley. The likely source of brine contamination in the shallow aquifers is brine that is produced with crude oil in the East Poplar oil field study area. Brine contamination has not only affected the water quality from privately owned wells in and near the East Poplar oil field, but also the city of Poplar's public water-supply wells.

Three water-quality types characterize water in the shallow aquifers; a fourth water-quality type in the study area characterizes the brine. Type 1 is uncontaminated water that is suitable for most domestic purposes and typically contains sodium bicarbonate and sodium/magnesium sulfate as the dominant ions. Type 2 is moderately contaminated water that is suitable for some domestic purposes, but not used for drinking water, and typically contains sodium and chloride as the dominant ions. Type 3 is considerably contaminated water that is unsuitable for any domestic purpose and always contains sodium and chloride as the dominant ions. Type 3 quality of water in the shallow aquifers is similar to Type 4, which is the brine that is produced with crude oil.

Electromagnetic apparent conductivity data were collected in the 106 square-mile area and used to determine extent of brine contamination. These data were collected and interpreted in conjunction with water-quality data collected through 2009 to delineate brine plumes in the shallow aquifers. Monitoring wells subsequently were drilled in some areas without existing water wells to confirm most of the delineated brine plumes; however, several possible plumes do not contain either existing water wells or monitoring wells. Analysis of groundwater samples from wells confirms the presence of 12.1 square miles of contamination, as much as 1.7 square miles of which is considerably contaminated
(Type 3). Electromagnetic apparent conductivity data in areas with no wells delineate an additional 5.8 square miles of possible contamination, 2.1 square miles of which might be considerably contaminated (Type 3 ). Storage-tank facilities, oil wells, brine-injection wells, pipelines, and pits are likely sources of brine in the study area. It is not possible to identify discrete oil-related features as likely sources of brine plumes because several features commonly are co-located. During the latter half of the twentieth century, many brine plumes migrated beyond the immediate source area and likely mix together in modern and ancestral Poplar River valley subareas.

\section{Introduction}

For more than half a century, millions of barrels of brine have been produced with oil from the East Poplar oil field and surrounding area. The brine, which contains 37,900 to 210,000 milligrams per liter (mg/L) dissolved solids, was placed in pits and ponds or injected into subsurface geologic units through disposal wells. Handling and disposal of the brine has resulted in contamination of not only the shallow aquifers in the East Poplar oil field, but also the Poplar River (Thamke and Craigg, 1997). The shallow aquifers primarily consist of unconsolidated sands and gravel that are as much as 45 feet (ft) thick and are overlain by unsaturated clay, silt, and sand that are as much as $100 \mathrm{ft}$ thick. The shallow aquifers are underlain by 700 to $1,000 \mathrm{ft}$ of impermeable Upper Cretaceous Bearpaw Shale (Bearpaw Shale).

The shallow aquifers are the only available source of potable groundwater in the area, and had provided water for more than 100 residents with household wells northeast of Poplar in addition to 2,900 residents that relied on the city of Poplar public water-supply wells. The city of Poplar, headquarters of the Fort Peck Tribal government, is downgradient from multiple sources of brine and brine-contaminated groundwater in the East Poplar oil field. Data collected by the USGS during 2009-10 confirmed that water from the city of Poplar's public water-supply wells is enriched in constituents that are present in oil-field brines (Peterman and 
others, 2010). As a result of the affected public-water supply wells, a pipeline was completed during 2011 that supplies treated water from the Missouri River to the city of Poplar and nearby residents, replacing the use of the shallow aquifers as a source of water (Debi Madison, Fort Peck Tribes, written commun., 2013).

Electromagnetic methods were first used to delineate brine plumes in the East Poplar oil field during the early 1990s (Thamke and Craigg, 1997). Areas with brine contamination were identified in more than 12 square miles $\left(\mathrm{mi}^{2}\right)$ of shallow aquifers in and near the East Poplar oil field. In the 10 years since the first delineation, dissolved-solids concentrations in groundwater changed markedly in and near brine contamination, yet dissolved-solids concentrations remained constant in areas unaffected by brine contamination (Thamke and Midtlyng, 2003). The changes in the groundwater quality indicated that the extent of brine contamination likely had changed since the early 1990s. The water-quality data were insufficient to delineate, with any detail, a new extent of brine contamination.

In 2003, the U.S. Geological Survey (USGS), in cooperation with the Fort Peck Tribes Office of Environmental Protection (FPOEP), initiated a follow-up investigation that combined historical and recent geophysical, hydrologic, and water-quality data with the objectives to delineate brine contamination, document movement of contamination, and identify possible brine sources in and near the East Poplar oil field. This investigation expanded on previous USGS studies (Levings, 1984; Thamke and Craigg, 1997; and Thamke and Midtlyng, 2003) and extended the study area southward to the northern edge of the Missouri River valley and westward to include the city of Poplar.

\section{Purpose and Scope}

This report delineates brine contamination in and near the East Poplar oil field using information collected by the USGS and other entities through 2009. As part of this report, a comprehensive historical map of oil-related features was compiled; the altitude and configuration of the top of the shallow aquifers and the Bearpaw Shale was determined; areas of low, moderate, and high apparent conductivity were delineated; and extent of brine contamination was interpreted and delineated.

This report is the fourth USGS publication that documents the results of this investigation to delineate brine contamination in and near the East Poplar oil field. Airborne electromagnetic data collected during 2004 and electromagnetic maps are published in Smith and others (2006a). Strontium isotope and major dissolved ion data collected during 2009 and 2010 by the FPOEP and USGS are published in Peterman and others (2010); however, only the major dissolved ion data from 2009 are used for interpretations in this report. Borehole geophysical data collected during 1993, 2004, and 2005 by the USGS and lithologic logs of these wells are published in Smith and others (2014).

\section{Description of Study Area}

The study area encompasses about $126 \mathrm{mi}^{2}$ and includes the city of Poplar, the East Poplar oil field, and most of the Northwest Poplar oil field (fig. 1). Land uses in the study area include dryland farming, livestock ranching, oil production, and residential development. The Poplar River flows south and west through the study area into the Missouri River that flows eastward near the southern edge of the study area. Throughout nearly all of the study area, shallow aquifers directly overlie the thick and impermeable Upper Cretaceous Bearpaw Shale and are the only available source of potable groundwater for residents in the study area (Thamke and Craigg, 1997). The shallow aquifers primarily consist of sand and gravel in Quaternary alluvium or Wiota Gravel, except in the northern one-quarter of the study area where shallow aquifers also can include sandstone in the Upper Cretaceous Fox Hills and Hell Creek Formations, sandstone interbedded with minor coal seams in the Tertiary Fort Union Formation, and gravel in the Tertiary Flaxville Formation. Quaternary alluvium and Wiota Gravel were deposited fluvially in a typical channel geometry pattern with variable sands and gravel. Previous investigations on geologic structure, stratigraphy, and hydrogeology in the East Poplar oil field study area are summarized by Thamke and Craigg (1997).

\section{Site Identification and Well-Naming Systems}

Site numbers are used to identify wells in the same manner as used in previous investigations (Thamke and Midtlyng, 2003; Thamke and Craigg, 1997; Thamke and others, 1996; Levings, 1984). Site numbers are based on the rectangular system for the subdivision of public lands (fig. 2). The number consists of as many as 14 characters and is assigned according to the location of a site within a given township ( $\mathrm{T}$ ), range (R), and section (sec.). The first three characters specify the township and its position north (N) of the Montana Base Line, whereas the next three characters specify the range and its position east (E) of the Montana Principal Meridian. The next two characters indicate the section; the next four characters indicate the position of the site within the section. The first letter denotes the quarter section (160-acre tract), the second letter denotes the quarter-quarter section (40-acre tract), the third letter denotes the quarter-quarter-quarter section (10-acre tract), and the fourth letter denotes the quarter-quarter-quarterquarter section (2.5-acre tract). These lettered subdivisions of the section are indicated as A, B, C, and D in a counterclockwise direction beginning in the northeast quadrant. The last two characters form a sequence number based on the order that a site was identified in that tract. For example, site number 28N51E22CBAC02 represents the second well identified in the $\mathrm{SW}^{1 / 4}$ of the $\mathrm{NE}^{1 / 4}$ of the $\mathrm{NW}^{1 / 4}$ of the $\mathrm{SW}^{1 / 4}$ in sec. 22 , T. 28 N., R. 51 E.

Wells also are identified by an alpha-numeric well name, allowing for ease of cross reference between wells plotted on the figures and tables in this report and on figures and tables in 

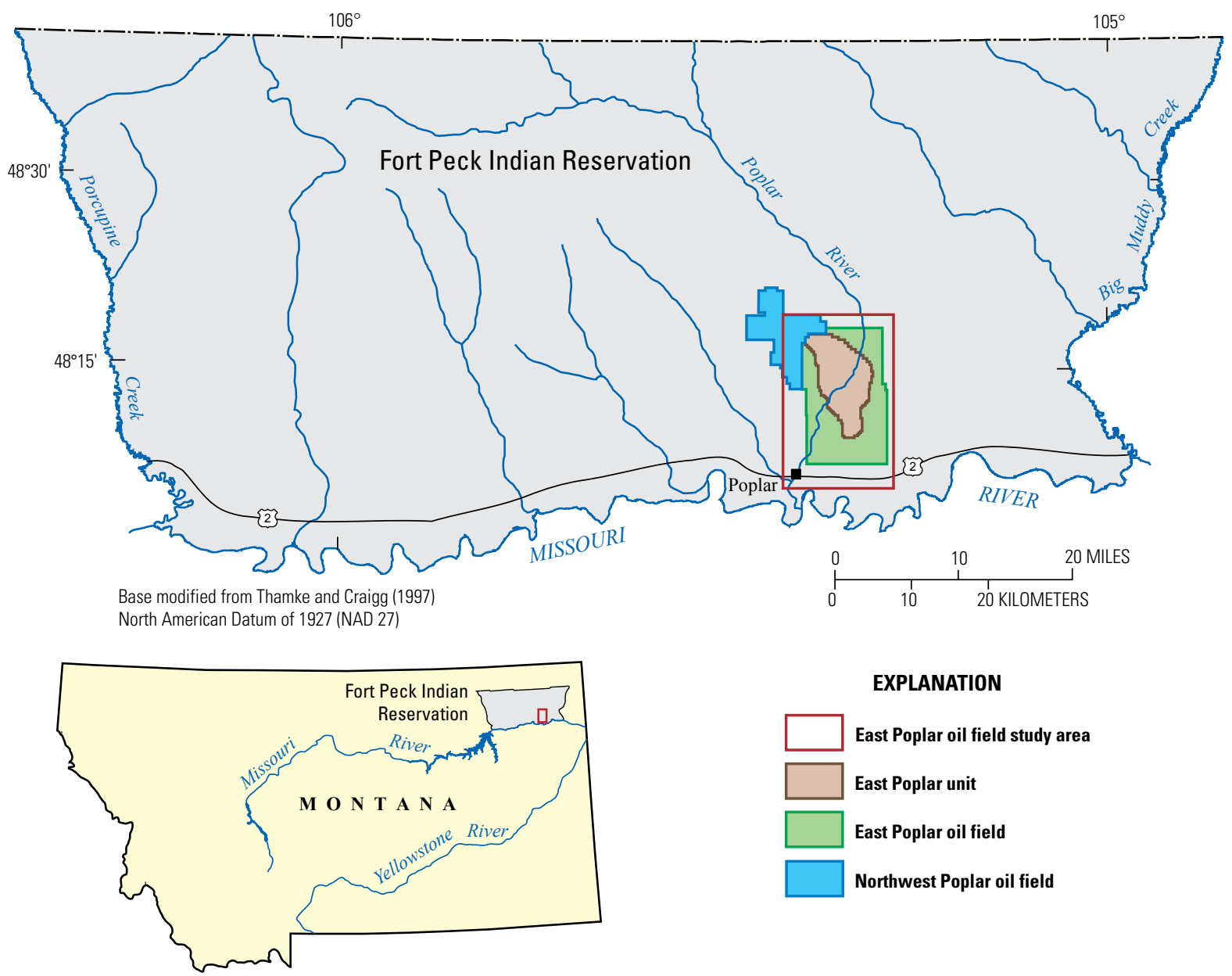

EXPLANATION

East Poplar oil field study area

East Poplar unit

East Poplar oil field

Northwest Poplar oil field

Figure 1. Location of study area.

numerous previous reports by the USGS and other agencies. The well name consists of as many as four alpha characters and four numeric characters. The alpha characters denote the well type: LAW - monitoring well installed for Land and Water Consulting, Inc.; MBMG-monitoring well installed by Montana Bureau of Mines and Geology; MOC - monitoring well installed for Murphy Oil Company; MSCA - monitoring well installed by Montana Salinity Control Association; PNR - monitoring well installed for Pioneer Natural Resources USA, Inc.; USGS - monitoring well installed for or by the USGS; and M or W-privately owned well. The first two numeric characters for USGS and MBMG monitoring wells denote the year that the well was drilled. The last two numeric characters for USGS monitoring wells denote the sequence that the wells were drilled during 1992, 1993, and 2009. The numeric characters for privately owned wells are assigned only as a convenient cross reference between relevant figures and tables. Privately owned wells that were drilled after September 1993 and not published in Thamke and others (1996) are numbered sequentially after M-57, the last well in the original 1996 list. Brine-injection wells and oil wells are identified using the well name provided by the Montana Board of Oil and Gas Conservation's (MBOGC) online oil and gas information system (Montana Board of Oil and Gas Conservation, 2005).

\section{Methods of Investigation}

This investigation of brine contamination in and near the East Poplar oil field included a comprehensive review of existing data and extensive collection of additional field data. Existing data for water wells, monitoring wells, oil wells, brine-injection wells, and water quality were obtained from various sources that are identified throughout this report.

As an initial step in this investigation, existing photographs, maps, and the MBOGC's online oil and gas information system (Montana Board of Oil and Gas Conservation, 2005) were used to develop a comprehensive map of oilrelated features in the study area dating from 1952 to 2005. Existing wells were sampled during 2003 to compare with historical water-quality information. To further delineate the 


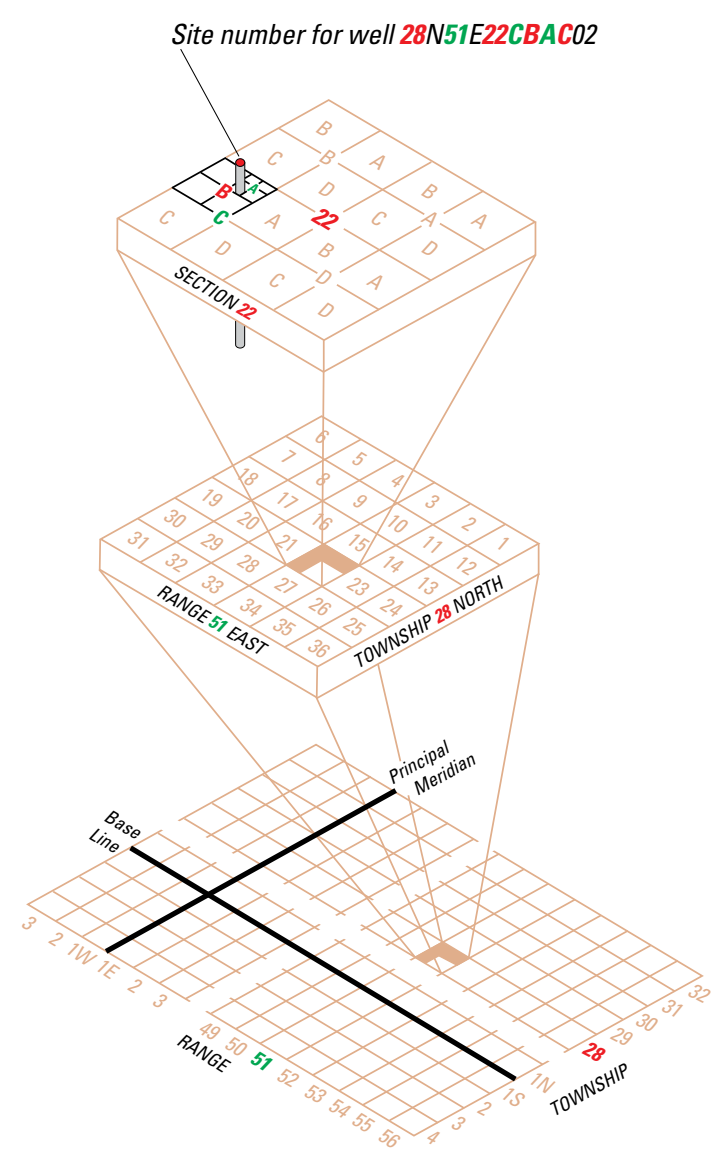

Figure 2. Diagram showing site-numbering system.

extent of potential brine contamination, an airborne electromagnetic survey was conducted over an area of about $106 \mathrm{mi}^{2}$ in 2004. Borehole natural gamma and electromagnetic data were collected in selected wells during 2004 and 2005 to provide vertical and lateral correlation at known points throughout the study area. Ground electromagnetic surveys were conducted in five small areas during 2005 to guide interpretation of relevant measurement sets. Monitoring wells were installed during 2006 for subsequent aquifer testing or in areas where high apparent conductivity values were recorded with the airborne electromagnetic equipment. Geologic information from maps and lithologic information from selected wells were used to develop maps showing the approximate altitude and configuration of the top of the shallow aquifers and the top of the Bearpaw Shale. Aquifer tests were conducted during 2007 in selected monitoring wells to determine aquifer characteristics. Monitoring wells were installed during 2009 to provide lithologic data in the southwest part of the study area. Water from monitoring wells was sampled between 2003 and 2009 to confirm if water was uncontaminated, moderately contaminated, or considerably contaminated. Previous data and the data collected during this investigation were used to delineate brine contamination in and near the East Poplar oil field.

\section{Historical Oil-Related Features}

Aerial survey photographs and maps obtained from eight discrete periods (1956, 1967, 1974/1975, 1980, 1991/1992, 1996, 2001, 2005) and data between 1952-2005 from the MBOGC's online oil and gas information system (Montana Board of Oil and Gas Conservation, 2005) were used to identify historical and existing oil-related features, such as pits and ponds, tank facilities, oil wells, and pipelines (fig. 3, table 1). Tank batteries were identified as cylindrical tanks at the site on the aerial photograph. Oil-well names and locations were obtained from MBOGC's online oil and gas information system (Montana Board of Oil and Gas Conservation, 2005). Linear features that seemed to connect two oil-related facilities on the photographs were delineated as pipelines. An early1990s field map from MOC was used to help locate pipelines, although many more pipelines were identified using the aerial photographs than were depicted on the MOC field map.

Oil-related features that were identified on the aerial photographs were hand-digitized into a Geographical Information System (GIS) coverage. Root-mean-square (RMS) errors between the registration tics placed on the photograph at road intersections and the inferred longitude and latitude coordinates of those locations ranged from 0.0 meters (1974, 1980, 1991, and 1992) to 0.037 (1967) and 0.042 meters (1956). Oil-related features identified on the 1996 digital orthophotographic quadrangle maps were transferred electronically to figure 3. If necessary, the digitized 1956-92 oil-related features were adjusted visually in the GIS coverage on a computer screen using the 1996 digital orthophotographic quadrangle maps.

Linear features from utilities, such as electrical and telephone lines, are not included in figure 3 . A powerline map delineated with 2004 electromagnetic data (fig. 6 from Smith and others, 2006a) was used to omit linear features that appeared on the photographs from utility lines. A map from NEMONT Telephone Cooperative, Inc. was used to omit linear features that appeared on the photographs from telephone lines (NEMONT Telephone Cooperative, Inc., 2005, written commun).

Terry Ross, field manager of Nautilus Poplar LLC [which currently (2014) manages most of the East Poplar Unit, an area of pooled oil production among several operators], reviewed figure 3 to verify the identified oil-related features. Mr. Ross identified several additional features that were neither visible in the photographs nor listed in MBOGC's online oil and gas information system (Montana Board of Oil and Gas Conservation, 2005). 


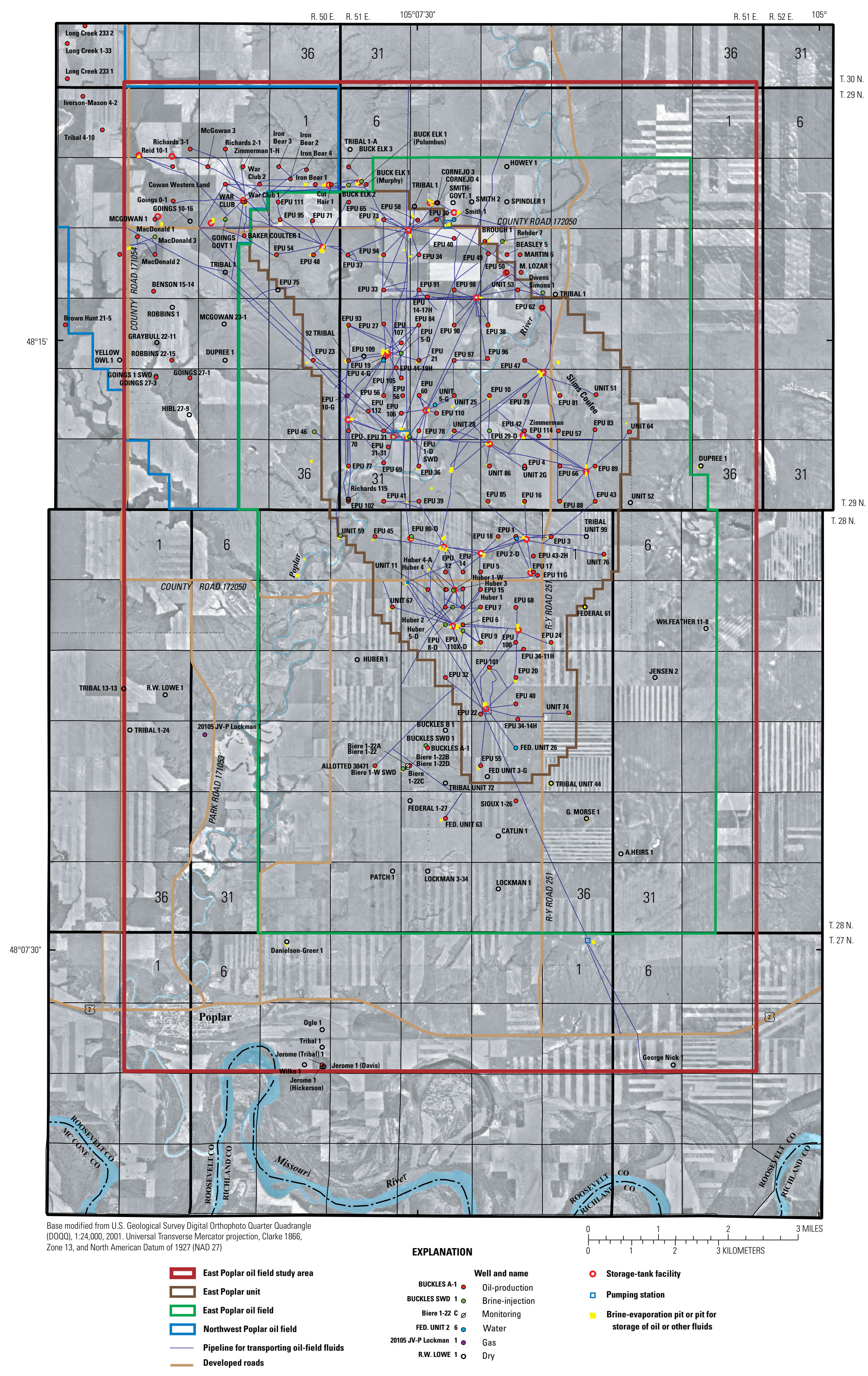

Figure 3. Oil-related features in and near the East Poplar oil field, 1952-2004. 
Table 1. Sources of aerial photographs and additional information used to identify various oil-related features in and near the East Poplar oil field.

[approx., approximately; USGS, U.S. Geological Survey; USDA, U.S. Department of Agriculture; T, township, N, north; R, range; E, east; NA, not applicable]

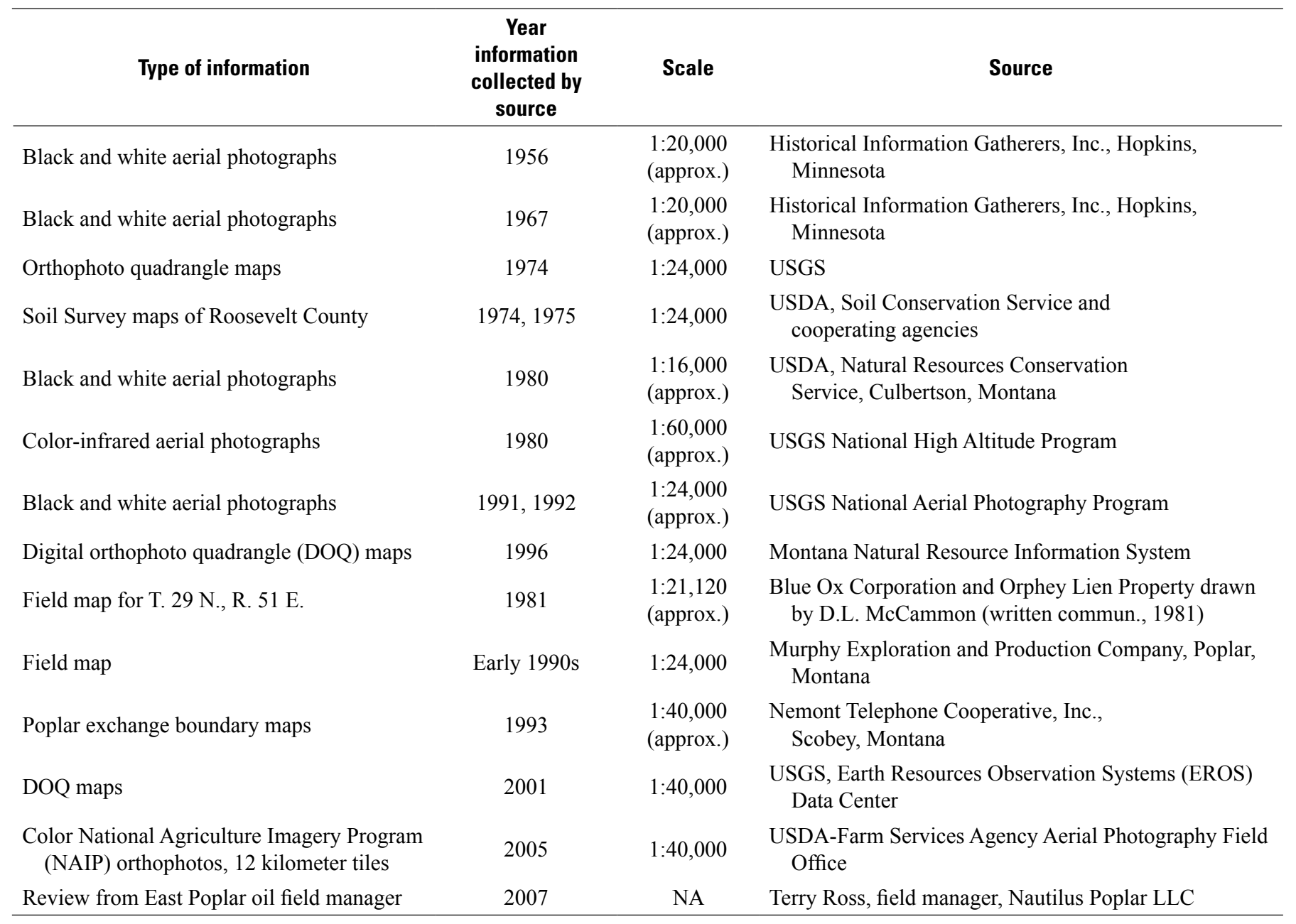

\section{Electromagnetic Geophysics}

Ground, airborne, and borehole electromagnetic data have been collected throughout the study area beginning in 1991. Ground electromagnetic data were collected using a variable-depth induction system (McNeill, 1979, 1983) that consisted of two consoles, a transmitter coil, and a receiver coil connected by a reference cable capable of 10-, 20-, and 40-meter (m) separation. Measurements were recorded as apparent conductivity in millisiemens per meter $(\mathrm{mS} / \mathrm{m})$.

Airborne electromagnetic and total field magnetic measurements were collected using an electromagnetic system carried by helicopter that consisted of six coil pairs with frequencies from about 400 to 140,000 hertz, as given in table 2 (Smith and others, 2006a, b). Five of the coil pairs were oriented in a horizontal, coplanar position and one of the coil pairs was oriented in a vertical, coaxial position.
The airborne electromagnetic data were processed by the contractor to level the data between flight lines and reduce the total field magnetic data (Smith and others, 2006a). Final processing of the electromagnetic data included computation of apparent resistivity (presented here as the reciprocal, apparent conductivity) at each frequency. The apparent conductivity maps show lateral variation of subsurface electrical conductivity at depths that increase as frequency decreases. In general, the depth of penetration or exploration increases as a function of decreasing frequency, thus the lower frequency apparent conductivity maps reflect features at greater depths than the higher frequency apparent conductivity maps.

There are several methods to convert the airborne electromagnetic data to more quantitative estimates of subsurface conductivity (Siemon, 2006). The most direct methods, such as differential or inversion methods, transform the airborne electromagnetic data to estimates of electrical conductivity at specific estimated depths. 
Table 2. Mean, minimum, and maximum differential depth at five frequencies measured with airborne electromagnetic horizontal coplanar coils, East Poplar oil field, 2004.

\begin{tabular}{rccc}
\hline $\begin{array}{c}\text { Nominal } \\
\text { frequency } \\
\text { (hertz) }\end{array}$ & $\begin{array}{c}\text { Mean } \\
\text { differential } \\
\text { depth } \\
\text { (meters) }\end{array}$ & $\begin{array}{c}\text { Minimum } \\
\text { differential } \\
\text { depth } \\
\text { (meters) }\end{array}$ & $\begin{array}{c}\text { Maximum } \\
\text { differential } \\
\text { depth } \\
\text { (meters) }\end{array}$ \\
\hline 400 & 39 & 20 & 64 \\
1,800 & 22 & 11 & 41 \\
8,200 & 13 & 6 & 32 \\
40,000 & 8 & 3 & 29 \\
140,000 & 3 & 1 & 15 \\
\hline
\end{tabular}

This report relies on the differential depth method described by Haung and Fraser (1996) to delineate the lateral extent of brine contamination within the shallow aquifers. The differential method derives a homogeneous halfspace model of the conductivity calculated for each time channel or electromagnetic frequency with an approximate depth. The high frequency data provide a measure of the shallow conductivity, and the deeper (lower frequency) halfspace conductivities are modified using the shallow information to give a more accurate measure of the conductivity at depth (Haung and Fraser, 1996).

Differential conductivity sections tend to smooth sharply defined layers (compared to layered-earth inversion sections) but still provide an excellent model of the conductivity, quickly and without the complex processing necessary for the inversion method. The differential depth sections are valuable as an overview of the conductivity distribution in the earth, and often to provide guidance and a starting model for more complex inversion depth sections.

Another method of interpretation involves inverse modeling of the airborne electromagnetic measurements to produce estimates of layered earth variations in electrical conductivity. The inversion method was applied along the flight lines (Condor Consulting, Inc., 2007) and was used in this report to determine a confidence limit for the depth of exploration of $45 \mathrm{~m}$ below land surface and provide a high resolution of vertical extent of brine contamination. The inverse model results were not used in this report to delineate the lateral extent of brine contamination because they require intensive computer modeling beyond the scope of this project.

Borehole geophysical logging consisted of electromagnetic conductivity and natural gamma measurements (Smith and others, 2014). All borehole equipment was thoroughly cleaned between each site to avoid cross-contamination. A digital borehole log acquisition system (Mount Sopris Instruments Company Ltd., 2002a, b, c) was used. Electromagnetic induction probes measure electrical conductivity in air-filled or water-filled pore spaces and require open boreholes or polyvinyl chloride (PVC) cased boreholes. Conductivity measurements commonly are used to provide logs with both resistivity and conductivity curves (Keys, 1989). The conductivity can be affected by the salinity of borehole and formation fluids and by the type of lithology encountered. Generally, pure carbonates, sands, and gravel have a lower conductivity (thus a higher resistivity) than clays or shale. The combination of gamma and conductivity logs provides information to distinguish high conductivity due to silt and clay, which has a high gamma signature, from conductive pore fluid.

\section{Electromagnetic Surveys}

A ground electromagnetic survey was first conducted by the USGS to delineate saline-water contamination in a $22 \mathrm{mi}^{2}$ portion (yellow outline, fig. 4) of the East Poplar oil field during summers of 1991 and 1992 (Thamke and Craigg, 1997). Saline-water contamination was identified in more than $12 \mathrm{mi}^{2}$ of shallow aquifers in and near the East Poplar oil field (plate 3, Thamke and Craigg, 1997).

In March-June 2002, a ground electromagnetic survey was conducted by Echotech Geophysical to delineate salinewater contamination in a $12 \mathrm{mi}^{2}$ area (light green outline, fig. 4) between the southern boundary of the early survey completed in the 1990s and the city of Poplar (Land and Water Consulting, Inc., 2003). The electromagnetic equipment was similar to that used in the early 1990s; however, the equipment was transported during 2002 with a tractor-cart mobile system to increase the rate and density of data collection. Potentially affected areas were identified to guide further subsurface investigation (p. 4-2 in Land and Water Consulting, Inc., 2003).

In August 2004, an airborne electromagnetic survey was conducted by Fugro Airborne, under contract to the USGS, to delineate brine contamination in a $106 \mathrm{mi}^{2}$ area (dark blue outline, fig. 4) located just north of the city of Poplar that includes all of the East Poplar oil field and much of the Northwest Poplar oil field (Smith and others, 2006a). Borehole geophysical data were collected in 20 wells concurrent with the airborne electromagnetic survey (Smith and others, 2014). Delineation of low, moderate, and high apparent conductivity is presented in the "Geospatial Distribution of Apparent Conductivity" section later in this report.

In September 2005, ground electromagnetic surveys were conducted by USGS in five areas that covered about $0.5 \mathrm{mi}^{2}$ (dark green outline, fig. 4 and data listed in appendix 1) and borehole electromagnetic methods were used by USGS in nine wells located throughout the study area (Smith and others, 2014). The ground electromagnetic methods were the same as those used in the early 1990s (Thamke and others, 1996). Apparent conductivity values from the 1990s ground survey and 2004 airborne survey were compared with values from 2005 to ensure that apparent conductivity had not changed markedly and to guide interpretation of the relevant range of differential depth. 


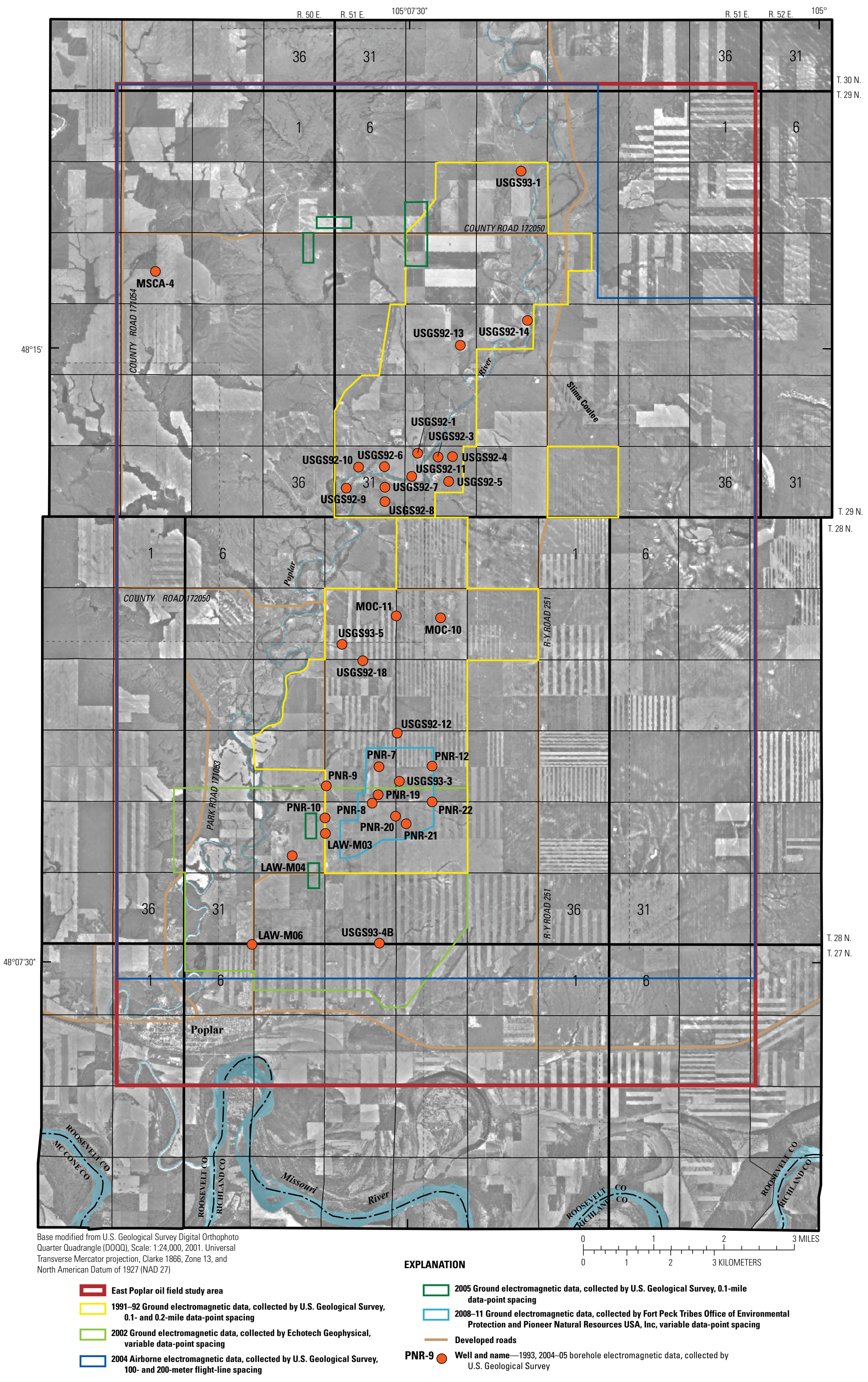

Figure 4. Locations of electromagnetic data collected in and near the East Poplar oil field. 
In May 2008, a ground electromagnetic survey was conducted by FPOEP and PNR to delineate saline-water contamination in a $1-\mathrm{mi}^{2}$ area (light blue outline, fig. 4) located about 3 mi northeast of the city of Poplar that includes a defined plume (Michael Jacobs, Pioneer Natural Resources, USA, Inc., written commun., 2008). The electromagnetic equipment was the same set of equipment as used in 1991-92, using methods described in Thamke and others (1996). Plume shape and apparent conductivity were delineated to provide a benchmark before the remediation that began in August 2008 at the site (Michael Jacobs, Pioneer Natural Resources, USA, Inc., written commun., 2008). Ground electromagnetic surveys were repeated in the same area during 2009-11 to monitor changes in plume shape and apparent conductivity during site remediation (Michael Jacobs, Pioneer Natural Resources, USA, Inc., written commun., 2009, 2010, and 2011).

\section{Monitoring-Well Installation}

During August and September 2006, 11 monitoring wells were drilled by Agri Industries, Inc. (Williston, North Dakota) with USGS and FPOEP oversight, and were completed in either Poplar River valley Quaternary alluvium or completed in Quaternary till or Wiota Gravel in higher altitudes (lithologic logs listed in appendix 2; locations in fig. 5 for wells labeled "USGS06"). All drill holes penetrated the Bearpaw Shale, allowing for the perforated interval of the well to be completed in the lowest part of the saturated Quaternary deposits. Wells were drilled using mud-rotary techniques. Except for wells completed specifically for aquifer testing, monitoring wells were installed in areas where high apparent conductivity values were measured with the airborne electromagnetic equipment during 2004.

During October 2009, seven monitoring wells were installed to define groundwater quality and aquifer characteristics in an area between the contaminated groundwater and the city of Poplar. The wells were drilled by Askin Drilling (Miles City, Montana) with USGS and FPOEP oversight, and were completed in either Poplar River valley Quaternary alluvium or in Quaternary Wiota Gravel east of the river (lithologic logs listed in appendix 2; locations in fig. 5 for wells labeled "USGS09"). All drill holes penetrated the Bearpaw Shale, allowing for the perforated interval of the well to be completed in the lowest part of the saturated Quaternary deposits. Wells were drilled using a combination of advanced-casing and mudrotary techniques.

The monitoring wells drilled during 2006 and 2009 were completed with polyvinylchloride (PVC) casing; machineslotted PVC casing was used in the perforated interval. Wells were installed with either 4 - or 5 -inch casing using a 0.02 -inch slot size for the perforated interval. For each well, a sediment trap (typically 10-ft long) was installed below the perforated interval. The annulus around the perforated interval of each well was packed either with silica sand or with natural cuttings material that caved around the well casing as the drill rod was withdrawn. The annulus above the pack was sealed with bentonite slurry; a cement pad was used as a surface seal. A steel protective casing with locking cover was set into the cement surface pad surrounding each well. Monitoring wells were developed by surging compressed air until the discharge remained clear. Details of well construction are reported in appendix 2 .

\section{Aquifer Tests}

Three constant-discharge aquifer tests were conducted by USGS during early summer 2007 using wells installed during 2006 (appendix 2). One test was conducted on March 27, 2007 in Quaternary alluvium that is about $65 \mathrm{ft}$ thick along the Poplar River in the SW $1 / 4$ NW $1 / 4 \mathrm{sec}$. 06, T. 27 N., R. 51 E. The pumped well (USGS06-11; fig. 5) and one of the observation wells (USGS06-9; fig. 5) were screened in the same gravel zone from about $36-64 \mathrm{ft}$. The second observation well (USGS06-10; fig. 5) was screened at a shallower depth with gravel pack extending to the bottom of the drill hole at $60 \mathrm{ft}$ below land surface (see well-construction details in appendix 2). No other water wells were nearby. Water levels in the two observation wells (located at distances of about $29 \mathrm{ft}$ west from the pumped well and $46 \mathrm{ft}$ southwest from the pumped well) were measured while discharge from the pumped well was held constant at 40 gallons per minute (gal/min) for $500 \mathrm{~min}$. Pumped water was discharged on the land surface, $30 \mathrm{ft}$ east of the pumped well. Lithologic logs described clay between the land surface and $36 \mathrm{ft}$ below the land surface, which would delay any infiltration of discharge water to the aquifer during the test. After 500 min, drawdown in the pumped well was $3.16 \mathrm{ft}$ and drawdown in the observation wells was $0.77 \mathrm{ft}$ in USGS06-9 and $0.66 \mathrm{ft}$ in USGS06-10 (appendix 3).

The second test was conducted on March 29, 2007 in Quaternary glacial deposits that are about $114 \mathrm{ft}$ thick east of the Poplar River in the SW $1 / 4$ NE $1 / 4$ sec. 06, T. 27 N., R. 51 E. The pumped well (USGS06-8; fig. 5) and the observation well (USGS06-7; fig. 5) were screened in the same interval of 94-114 ft; this interval mostly is gravel with some clay layers (appendix 2). Static-water levels were about 59 $\mathrm{ft}$ below the land surface, which is above the gravel interval that the wells have screened casing. No other water wells were nearby. The observation well was located about $53 \mathrm{ft}$ east of the pumped well. Pumped water was discharged on the land surface, $30 \mathrm{ft}$ south of the pumped well. Water levels in the pumped well and observation well were measured while discharge from the pumped well was held constant at $12.1 \mathrm{gal} /$ min for $665 \mathrm{~min}$. After $660 \mathrm{~min}$, drawdown in the pumped well was $9.13 \mathrm{ft}$ and drawdown in the observation well was $0.14 \mathrm{ft}$ (appendix 4). 


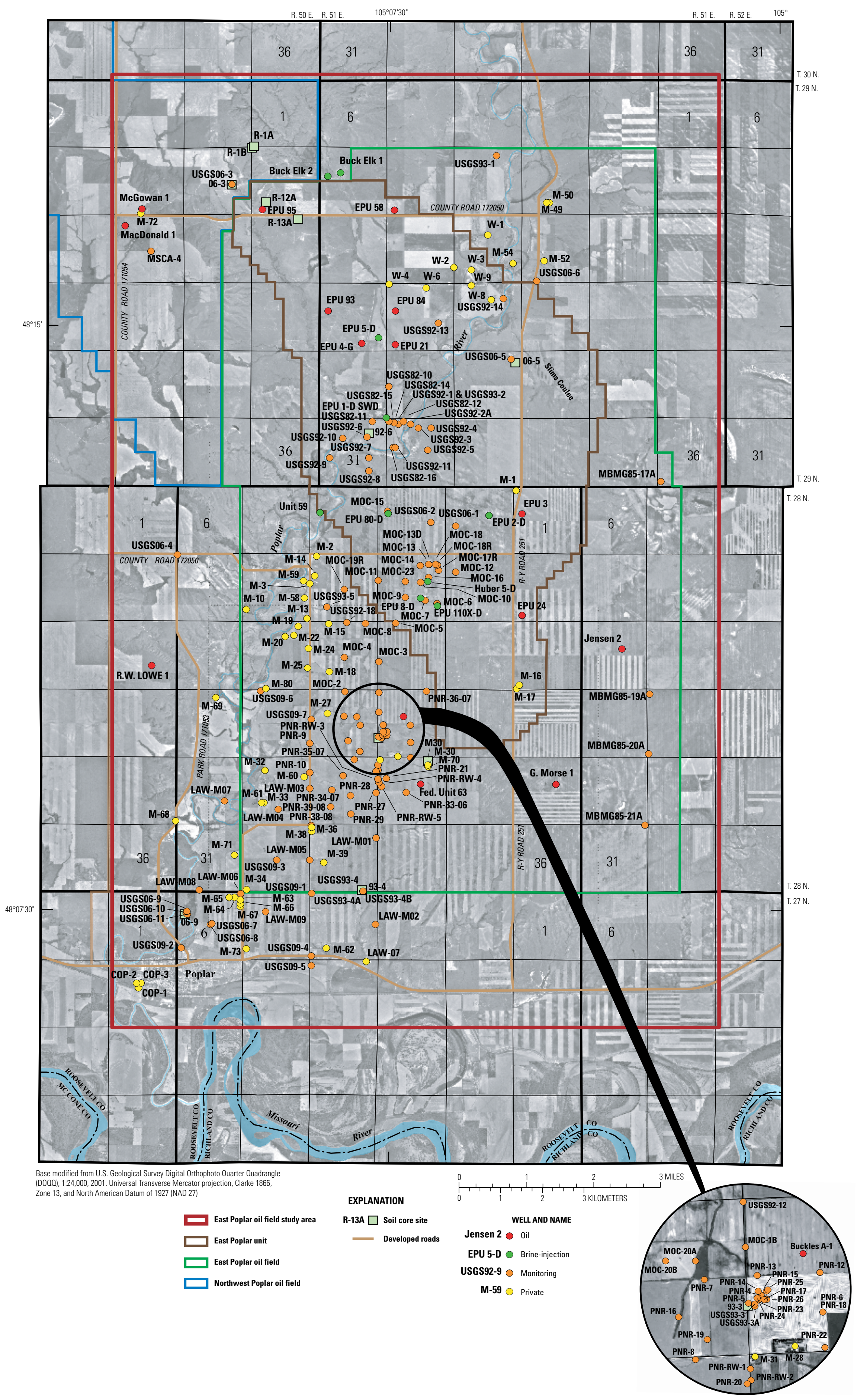


The third test was conducted during June 26-27, 2007, in Quaternary glacial deposits at the same site as the second test, using well USGS06-7 as the pumped well and USGS06-8 as the observation well (fig. 5). Pumped water was discharged on the land surface, $30 \mathrm{ft}$ south of the pumped well. Water levels in the pumped well (USGS06-7; fig. 5) and the observation well (USGS06-8; fig. 5) were measured while discharge from the pumped well was held constant at $20.0 \mathrm{gal} / \mathrm{min}$ for $1,920 \mathrm{~min}$. After 1,920 min, drawdown in the pumped well was $5.89 \mathrm{ft}$ and drawdown in the observation well was $0.14 \mathrm{ft}$ (appendix 4).

\section{Water-Quality Data}

Water-quality data were collected in and near the East Poplar oil field between September 2000 and October 2009 by two agencies (FPOEP and USGS) and six private companies [HKM Engineering, Inc. (HKM); HydroSolutions, Inc. (HSI); Land and Water Consulting, Inc. (LAW); Murphy Oil Company (MOC); MSE-HKM, Inc. (MSE); and Post Buckley Schuh \& Jernigan, Inc. (PBS\&J)]. Water-quality data are listed in appendixes 5 through 7; locations of water wells are shown in figure 5 .

Methods for collection of water-quality samples by the FPOEP and analysis by Energy Laboratories, Inc., Billings, Mont. are documented and filed with the U.S. Environmental Protection Agency (USEPA; described in "Sampling and Analysis Plans," Nathan M. Wiser, U.S. Environmental Protection Agency, written commun., 1999 and 2000). Methods for collection and analysis of water-quality samples by the USGS are documented and described in Thamke and others (1996) and Thamke and Midtlyng (2003). Methods for collection of water-quality samples by HKM and MSE are described in CH2M Hill (2000). Methods for collection of water-quality samples by HSI are described in "Groundwater sampling techniques used by HydroSolutions Inc. for Murphy Oil Corporation monitoring wells, 1999 to 2000" (Mark Nitz, HydroSolutions, Inc., written commun., 2005). Methods for collection of water-quality samples by LAW and PBS\&J are described in Land and Water Consulting, Inc. (2003). Waterquality sample methods used by MOC are similar to those documented for USGS. MOC water-quality samples were collected as replicates to USGS samples. Water-quality samples collected by HSI, HKM, LAW, MOC, MSE, and PBS\&J were analyzed by Energy Laboratories, Inc., Billings, Mont., using similar methods as described by USEPA ("Sampling and Analysis Plans," Nathan M. Wiser, U.S. Environmental Protection Agency, written commun., 1999 and 2000).

The quality of analytical results reported for waterquality samples was assessed by calculation of charge balance as well as analyses of equipment rinsate samples and replicate samples. The charge balance of major ions was calculated for all samples that are in appendix 5 using methods described in Lambing (2006). Samples with a charge balance outside the range of -10 percent to +10 percent are noted in appendix 5 and were not used to delineate brine contamination. Samples of rinsate water were collected before and during sampling events by the USGS in September 2003 and March 2007. Samples of rinsate water were analyzed for physical properties and major ions in 2003 and 2007 (appendix 6) and for fuel ethers, petroleum compounds, and radionuclides in 2007 (appendix 7). Tap water used for routine cleaning of the equipment and for the rinsate samples was obtained from an outside spigot at the USGS Montana Water Science Center office in Helena, Mont., before each sampling event. All major-ion concentrations in water samples collected by the USGS in 2003 and 2007 were greater than concentrations in rinsate samples. Except for toluene, all other fuel ethers, petroleum compounds, and radionuclides concentrations in water samples collected by the USGS in 2003 and 2007 were greater than concentrations in rinsate samples.

Replicates were collected and analyzed by the USGS in 2003 and 2007 (appendixes 5 and 7). The relative percent difference of the major-ion concentrations between replicate samples was determined using methods described by Dodge and others (2009) and Taylor (1987). The relative percent difference did not exceed 10 percent except for potassium in a sample from MOC-11 (11 percent). The concentrations of fuel ethers and petroleum compounds in replicate samples were identical and the relative percent difference was zero percent. The relative percent difference of radionuclides did not exceed 12 percent.

\section{Altitude and Configuration of Top of Shallow Aquifers}

Geologic information obtained from about 250 lithologic logs for monitoring and privately owned wells, and geology mapped by Colton (1963a and 1963b) were used to determine the approximate altitude and configuration of the top of shallow aquifers (fig. 6). 


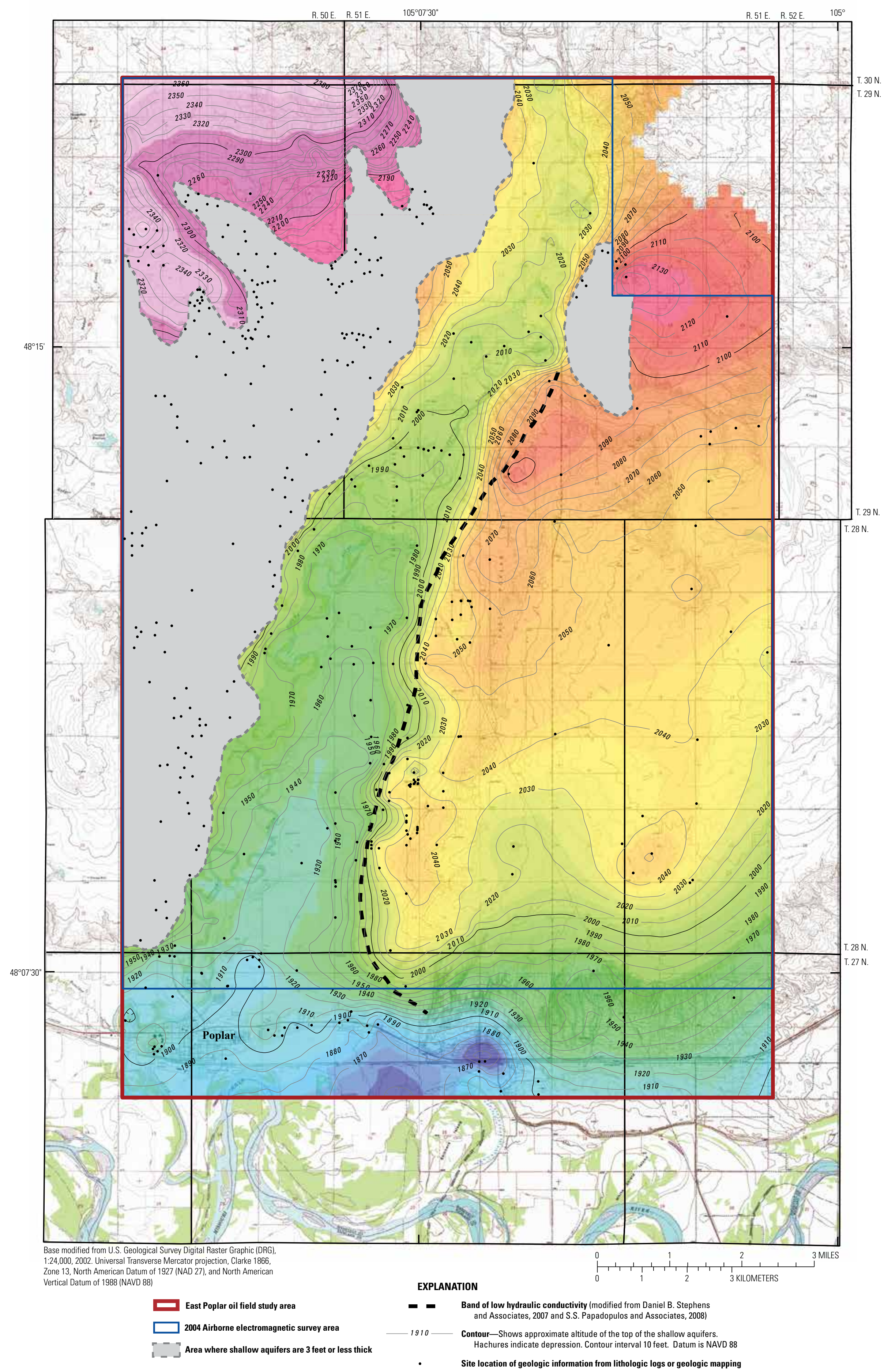

Figure 6. Approximate altitude and configuration of the top of the shallow aquifers in and near the East Poplar oil field. 
Lithologic logs for monitoring wells are published in reports from various agencies. Lithologic logs for privately owned wells were obtained through the MBMG GroundWater Information Center (http://mbmggwic.mtech.edu/) and through the paper files at the Fort Peck Indian Health Service accessed by FPOEP personnel in Poplar, Mont. (1990). The FPOEP verified the location of selected privately owned wells through site visits and discussions with well owners. Lithologic logs for wells drilled into the gravel deposits that yielded water were selected to determine the altitude of the shallow aquifers. Lithologic logs for wells drilled to the Bearpaw Shale that did not report data for gravel deposits were selected to determine areas lacking shallow aquifers. A band of limited groundwater flow or minimal gravel deposits has been interpreted in two hydrologic modeling investigations (Daniel B. Stephens \& Associates, Inc., 2007; S.S. Papadopulos \& Associates, Inc., 2008). This band is shown in figure 6. More than 300 locations where the Bearpaw Shale is at the land surface (Colton, 1963a and 1963b) were used to delineate areas where the shallow aquifers are thin (less than $3 \mathrm{ft}$ thick) or do not exist; these areas are shaded gray in figure 6. The USGS National Elevation Dataset (U.S. Geological Survey, 2008) was used to define the top of the shallow aquifers in areas where they extend to the land surface.

Nearly 700 data points were gridded using linear kriging methods with a spherical variogram model and a cell size of $275 \mathrm{~m}$. Contour lines from the gridded data that delineate the altitude and configuration of the top of the shallow aquifers were reviewed and manually adjusted where needed. The resulting map of approximate altitude and configuration of the top of the shallow aquifers is presented in figure 6 .

\section{Altitude and Configuration of Top of Upper Cretaceous Bearpaw Shale}

Geologic information obtained from nearly 300 lithologic logs for monitoring and privately owned wells and geology mapped by Colton (1963a and 1963b) was used to determine the approximate altitude and configuration of the top of the Bearpaw Shale (fig. 7). Lithologic logs for monitoring wells are published in reports from various agencies. Lithologic logs for privately owned wells were obtained through the MBMG Ground-Water Information Center (http://mbmggwic. mtech.edu/) and through the paper files at the Fort Peck Indian Health Service accessed by FPOEP personnel in Poplar, Mont. (1990). The FPOEP verified the location of selected privately owned wells through site visits and discussions with well owners. Lithologic logs for wells drilled into the Bearpaw Shale were selected to determine the approximate altitude of the Bearpaw Shale. In geographic areas lacking information, lithologic logs for wells that were completed above the Bearpaw Shale were selected to constrain the top of the Bearpaw Shale to an altitude below the well depth. More than 300 locations where the Bearpaw Shale is at the land surface (Colton, 1963a and 1963b) were used with the USGS National Elevation
Dataset (USGS, 2008) to determine the approximate altitude of the top of the Bearpaw Shale.

Nearly 700 data points were gridded using linear kriging methods with a spherical variogram model and a cell size of $275 \mathrm{~m}$. Contour lines from the gridded data that delineate the altitude and configuration of the top of the Bearpaw Shale were reviewed and manually adjusted where needed. The resulting map of approximate altitude and configuration of the top of the Bearpaw Shale is shown in figure 7.

\section{General Hydrogeology of Shallow Aquifers}

The shallow aquifers primarily consist of Quaternary alluvium or Wiota Gravel, except in the northern one-quarter of the study area where shallow aquifers also can include the Upper Cretaceous Fox Hills Formation, Upper Cretaceous Hell Creek Formation, Tertiary Fort Union Formation, or Tertiary Flaxville Formation. These aquifers are the only available source of potable groundwater for residents of the study area (Thamke and Craigg, 1997). Wells completed in these aquifers generally provide sufficient yields and, in uncontaminated areas, potable water for domestic purposes. Few wells are completed below these shallow aquifers because the underlying Bearpaw Shale is impermeable and 700-1,000 ft thick. Previous investigations describe the hydrogeology in parts of this study area (Thamke and Craigg, 1997; Land and Water Consulting, 2003; Daniel B. Stephens \& Associates, Inc., 2007; and S.S. Papadopulos \& Associates, Inc., 2008). Additional hydrogeologic information collected during this investigation is described in the following section.

\section{Groundwater Occurrence and Movement}

Groundwater in the shallow aquifers occurs mainly under unconfined or semiconfined conditions that can vary depending on the heterogeneity of the clays, silts, sands, and gravel in the aquifer material and the overlying unsaturated deposits. Depth to water level below land surface generally ranges from a few feet within the Poplar River valley to about $130 \mathrm{ft}$ in the southeast part of the study area (Thamke and others, 1996), and altitude of the top of the shallow aquifers ranges from about $1,860 \mathrm{ft}$ in the southern part of the study area to about 2,370 ft in the northwestern part of the study area (fig. 6). Along the western part of the Poplar River valley and in the northeastern corner of the study area, there is limited or no groundwater availability because the Bearpaw Shale is within three $\mathrm{ft}$ of the land surface, the shallow aquifers are not present, or both (gray-shaded area in fig. 6). Fresh water recharge to the shallow aquifers is by infiltration of precipitation, streamflow, and groundwater movement from upgradient areas. Water in the shallow aquifers is discharged through base flow, evapotranspiration, springs, and water withdrawals (Thamke and others, 1996). 


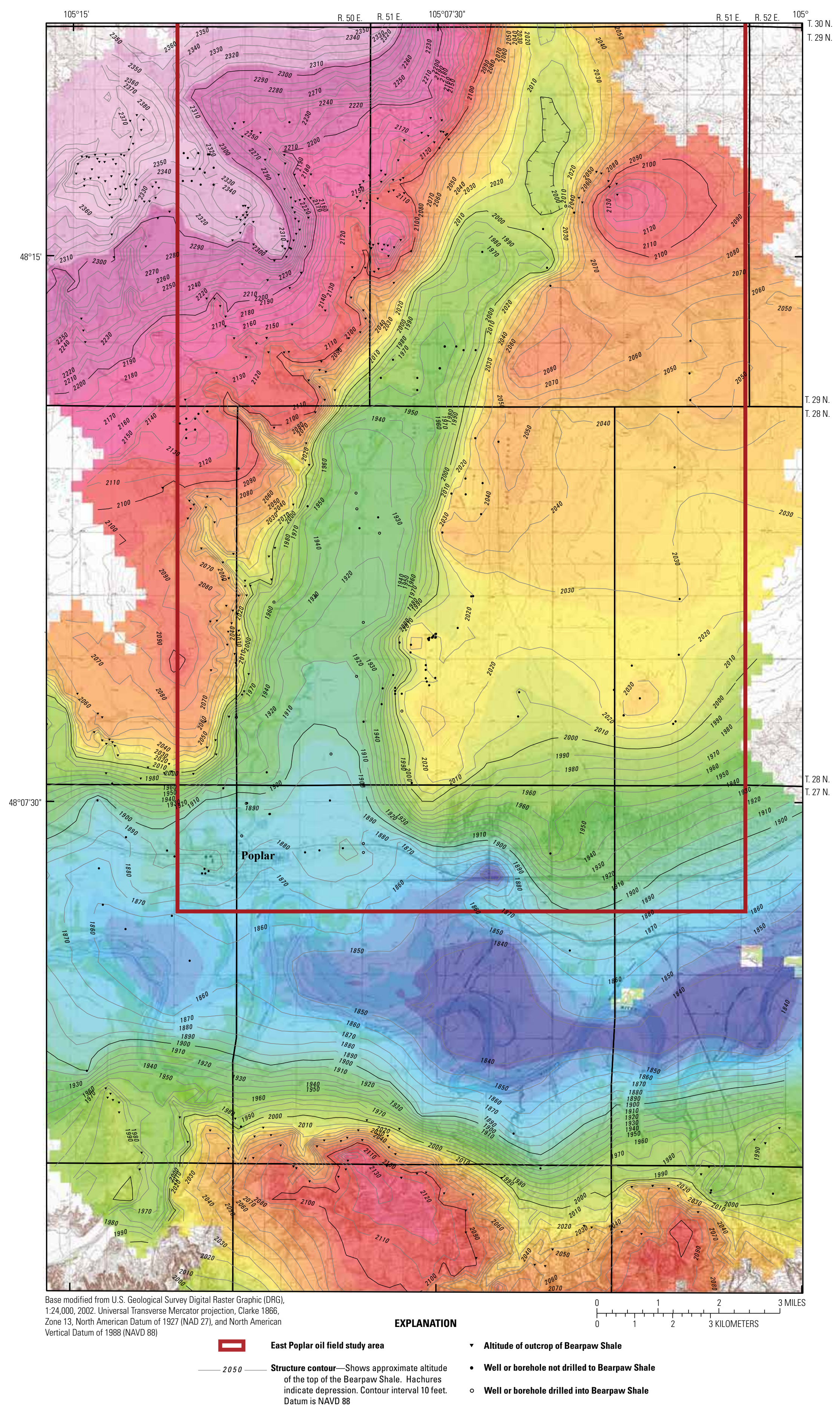

Figure 7. Approximate altitude and configuration of the top of the Upper Cretaceous Bearpaw Shale in and near the East Poplar oil field 
The presence or absence of sands and gravel in the shallow aquifers strongly affects groundwater occurrence and movement. Quaternary alluvium and Wiota Gravel were deposited fluvially in a typical channel-geometry pattern with variable sands and gravel content. These sands and gravel likely provide preferential flow paths for groundwater. The presence of gravel channels and the heterogeneity of the stratigraphy in the Wiota Gravel were apparent along four cross-sections using direct current electrical resistivity methods and lithologic information from nearby monitoring wells (Bureau of Land Management, 2007). Three zones of low (less than $7 \mathrm{ft} / \mathrm{d}$ ) hydraulic conductivity were initially defined in a small area by Daniel B. Stephens \& Associates, Inc. (2007) and subsequently extended to a narrow band of low hydraulic conductivity where the Wiota Gravel is thin or absent by S.S. Papadopulos \& Associates, Inc. (2008) using water-level observations, slug-test and lithologic data from monitoring wells, water-quality distribution, and qualitative interpretation of electromagnetic data. This band of low hydraulic conductivity (fig. 6) generally parallels the eastern ancestral Poplar River valley incision into the Bearpaw Shale (fig. 7) in a northeastern-southwestern orientation. The low hydraulic conductivity band also partially separates groundwater altitudes in this area by about $40 \mathrm{ft}$ (fig. 6; Thamke and Craigg, 1997). Small gravel channels likely cross this band and hydraulically connect the upper and lower terraces of the Wiota Gravel in spatially limited areas, as described by S.S. Papadopulos \& Associates, Inc. (p. 16, 2008).

Seasonal and multi-year water-level fluctuations were negligible throughout most of the study area. Continuous water-level records available for monitoring wells USGS93-1 and USGS93-4B (fig. 5) during January 2007 through September 2009 indicated little to no seasonal patterns, and annual amplitudes were less than $2 \mathrm{ft}$ (National Water Information System site names/numbers: USGS93-1/ 481713105052804 and USGS93-4B/480746105080104 in U.S. Geological Survey, 2010). Water levels in well USGS93-1, which is completed in Poplar River alluvium and located within 0.25 mile of the river, rose $0.5-2 \mathrm{ft}$ every spring during the 3-year period of record. Water levels in well USGS93-4B, which is completed in Wiota Gravel near the southern part of the study area, responded inversely to barometric pressure on a daily basis and did not follow a seasonal pattern during the 3-year period of record. Continuous waterlevel records available for monitoring well MBMG85-17A (fig. 5) during July 2000 through December 2009 indicated seasonal fluctuations were less than $1.5 \mathrm{ft}$ and annual amplitudes were less than $2 \mathrm{ft}$ (Ground-Water Information Center well name/number: MBMG85-17A/3533 in Montana Bureau of Mines and Geology, 2010). Water levels in well MBMG85$17 \mathrm{~A}$, which is completed in outwash deposits within Slims Coulee, generally were highest in early summer from recharge of snowmelt and late-spring/early summer precipitation.
Water levels measured more than twice in most monitoring wells during a multi-year period fluctuated less than $5 \mathrm{ft}$, and in wells that were unaffected by pumping the water-level fluctuations were less than $1 \mathrm{ft}$ (appendix $\mathrm{C}$ in Land and Water Consulting, 2003; p. 4 and appendix C in S.S. Papadopulos \& Associates, Inc., 2007).

Generalized potentiometric surface and direction of groundwater movement in shallow aquifers have been determined for several time periods and within several parts of the study area (fig. 6 in Thamke and Craigg, 1997; fig. 4-5 in Land and Water Consulting, 2003; fig. 2 in Daniel B. Stephens \& Associates, Inc., 2007; and fig. 2 in S.S. Papadopulos \& Associates, Inc., 2008). Where these potentiometric surfaces overlap, gradients and direction of movement are similar. Water in the shallow aquifers generally moves towards the Poplar River where it merges with southward-flowing groundwater in the Poplar River valley towards the Missouri River, ultimately merging with eastward-flowing groundwater in the larger Missouri River valley.

\section{Hydraulic Characteristics}

Numerous aquifer and slug tests have been conducted throughout the study area to determine general hydraulic characteristics of the shallow aquifers (Thamke and Craigg, 1997; Land and Water Consulting, 2003; HKM Engineering, Inc., 2007a; HKM Engineering, Inc., 2007b; and HKM Engineering, Inc., 2007c). The hydraulic characteristics computed from aquifer-test data are summarized in table 3 . Three constant-discharge aquifer tests were conducted during March and June 2007 as part of this investigation to determine general hydraulic characteristics of the shallow aquifers between the city of Poplar and potential sources of contamination (data in appendixes 3 and 4).

A constant-discharge aquifer test was conducted on March 27, 2007, in alluvium along the Poplar River north of the city of Poplar, using one pumped well and two observation wells (USGS06-11, USGS06-9, and USGS06-10; lithology and completion details in appendix 2; locations on fig. 5). The general geology of the site consists of Quaternary alluvium that unconformably overlies the Bearpaw Shale. According to the lithologic logs, the alluvium consists of interbedded sand, clay, and gravel.

Two constant-discharge single-observation-well aquifer tests were conducted on March 29 and June 25, 2007, in Wiota Gravel northeast of the city of Poplar, using wells USGS06-7 and USGS06-8 (lithology and completion details in appendix 2; locations on fig. 5). On March 29, the pumped well was USGS06-8 and on June 25, the pumped well was USGS06-7. On the basis of lithologic logs for the two wells, the general geology of the site consists of about $30 \mathrm{ft}$ of well-rounded coarse gravel that unconformably overlies the Bearpaw Shale. 
Table 3. Hydraulic characteristics of shallow aquifers in and near the East Poplar oil field, 1985-2007.

$\left[\mathrm{ft} / \mathrm{d}\right.$, foot per day; $\mathrm{ft}^{2} / \mathrm{d}$, square foot/day]

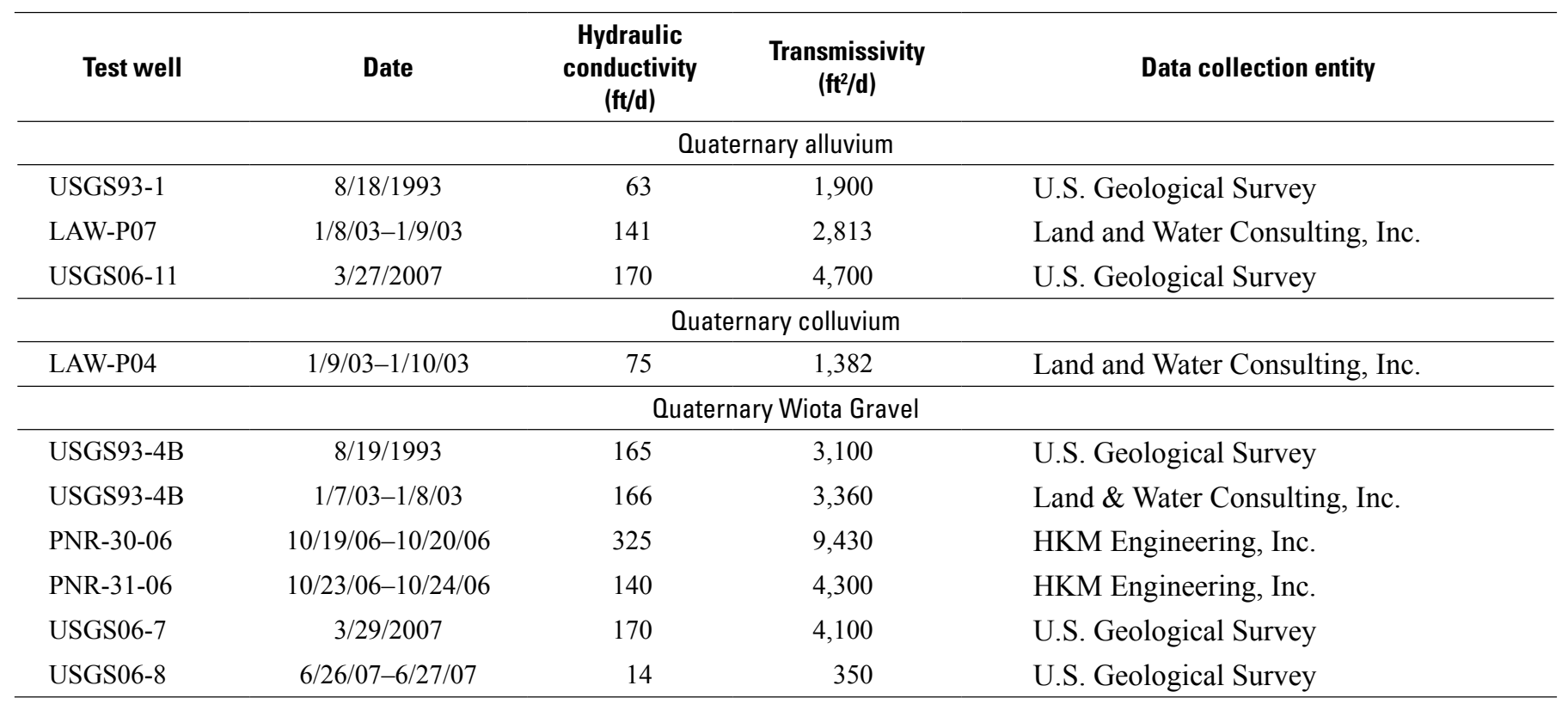

The aquifer-test data at the alluvium test site (USGS0611; fig. 5) were analyzed using Theis methods and modified for delayed yield (Boulton, 1963; Lohman, 1979). The results (on file at Wyoming-Montana Water Science Center, Helena, Mont.) indicate semi-confined conditions during short-term pumping. The transmissivity value computed at this site was $4,700 \mathrm{ft}^{2} / \mathrm{d}$ and hydraulic conductivity value was $170 \mathrm{ft} / \mathrm{d}$ (table 3). The transmissivity and hydraulic conductivity values are larger than other values for alluvium in the study area, yet are within typical ranges for sand and gravel aquifers (Freeze and Cherry, 1979).

The single-observation-well aquifer-test data at the Wiota Gravel site were analyzed using Cooper-Jacob methods as described in Lohman (1979). Transmissivity and hydraulic conductivity values computed for the two tests, respectively, were $350 \mathrm{ft}^{2} / \mathrm{d}$ and $14 \mathrm{ft} / \mathrm{d}$ (pumping well USGS06-8) and 4,100 ft $2 / \mathrm{d}$ and $170 \mathrm{ft} / \mathrm{d}$ (pumping well USGS06-7). The values computed for the test with pumping well USGS06-8 are an order of magnitude less than any values computed for Wiota Gravel in the study area (table 3 ) and possibly indicate that well USGS06-8 is completed in a poorly connected gravel channel. The values computed for the test with pumping well USGS06-7 are consistent with the range of values for Wiota Gravel in the study area (table 3).
Slug tests were conducted at 18 wells during February and March 2007 to determine hydraulic characteristics in a $9 \mathrm{mi}^{2}$ area northeast of the city of Poplar (data in HKM Engineering, Inc., 2007a; HKM Engineering, Inc., 2007b; and HKM Engineering, Inc., 2007c; site map in Daniel B. Stephens \& Associates, Inc., 2007, fig. 4). Hydraulic conductivity values ranged from 1 to $98 \mathrm{ft} / \mathrm{d}$ and were substantially less than hydraulic conductivity values computed from aquifer-test data collected from nearby wells. As noted in Lohman (1979, p. 27), this method strictly is applicable only to fully penetrating or fully screened wells in confined aquifers of rather low transmissivity and the slug-test method for wells in unconfined aquifers provides results that should be regarded with skepticism. For these reasons, hydraulic characteristics computed from aquifer-test data are considered to be more reliable than those computed from slug-test data; however, the slug-test data were useful in a qualitative sense by identifying zones of low hydraulic conductivity that were extended by S.S. Papadopulos (2008) to a narrow band of low hydraulic conductivity. The thicknesses of the Wiota Gravel reported in lithologic logs for wells located along this band range from about 0 to less than $6 \mathrm{ft}$. 


\section{Groundwater Quality}

The quality of water in the shallow aquifers in the study area is highly variable and is dependent on location relative to sources of contamination. Sodium, magnesium, bicarbonate, sulfate, and chloride are the dominant ions in uncontaminated and contaminated water from most wells completed in the shallow aquifers. Sodium and chloride are the dominant ions in brine that is produced with oil in the study area. Of these dominant ions, only chloride generally exhibits a conservative behavior, is present in natural water at low concentrations, and present in brine at very high concentrations (Hem, 1985; appendix 5, this report). Therefore, chloride concentration is used primarily to classify types of groundwater. There are four principal water types in the study area (Levings, 1984; Thamke and Craigg, 1997; and Thamke and Midtlyng, 2003). Distinguishing characteristics of each water type is described in Thamke and Craigg (p. 16 and table 3, 1997) and Thamke and Midtlyng (table 1,2003). The chloride and dissolvedsolids concentration ranges and dominant ions for each water type have been updated for this report (table 4) using data collected between September 2000 and December 2009 (appendix 5).

Table 4. Characteristics of water types in selected wells completed in and near the East Poplar oil field, 1952-2009.

[Chloride and dissolved solids concentration ranges modified from table 1 of Thamke and Midtlyng (2003) using additional data collected between September 2000 and December 2009; mg/L, milligrams per liter]

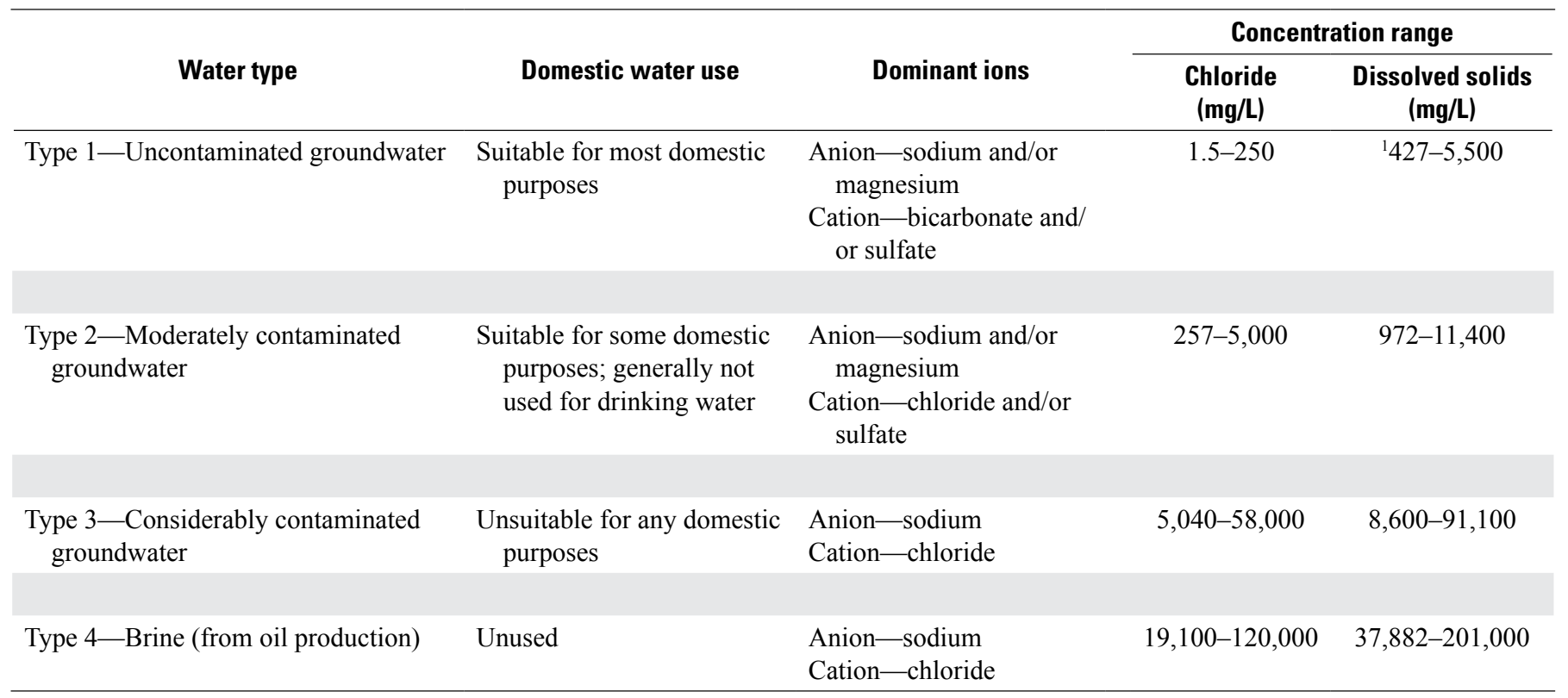

${ }^{1}$ The atypically large dissolved-solids concentration of 41,100 milligrams per liter in water from MSCA-4 primarily is from substantial concentrations of sulfate and is not included in this table for Type 1 water. 


\section{Geophysical Properties}

Electromagnetic geophysical methods can be used to measure the cumulative electrical conductivity of the soil and water matrix (McNeill, 1980). The unit of apparent conductivity for these methods is millimho per meter $(\mathrm{mmho} / \mathrm{m})$. Application and interpretation of electromagnetic surveys in oil fields must be approached with care because of the presence of noise produced by power lines, pipes, metal tanks, and other oil production infrastructure. Generally, apparent conductivity values are low for water with small concentrations of dissolved ions, and apparent conductivity can substantially increase for water with large concentrations of dissolved ions because the ions in solution conduct the electrical current. For example, an aquifer containing saline water will have higher apparent conductivity than if the same aquifer contained fresh water (Thamke and others, 1996). Water sampled during 1963-2009 from water wells completed in shallow aquifers in this study area contained dissolved-solids concentrations that ranged from 427 to $114,000 \mathrm{mg} / \mathrm{L}$ and specific conductivity values that ranged from 645 to 143,000 microsiemens per centimeter $(\mathrm{mS} / \mathrm{cm})$. In the East Poplar oil field, the presence of moderately conductive glacial tills and highly conductive shale bedrock also present challenges in interpretation of the electromagnetic data to delineate areas of conductive brinecontaminated groundwater. Consequently, integrated interpretation of geology, oil-field infrastructure data, hydrology, and geophysics is needed to interpret the subsurface extent of saline waters.

\section{Geospatial Distribution of Apparent Conductivity}

Interpretation of the 2004 airborne electromagnetic data required evaluation of data that most likely reflect subsurface salinity in shallow aquifers. Apparent conductivity values for differential depths that are located within the shallow aquifers were selected as most likely to delineate conductivity in the aquifer materials defined by drilling. The top of the shallow aquifers (fig. 6) was used to guide selection of apparent conductivity at the shallowest differential depths. Throughout the study area, the bottom of the shallow aquifers can be defined by the top of the Bearpaw Shale (fig. 7). Dense, saline water in the shallow aquifers generally flows near or along the top of the Bearpaw Shale and likely preferentially along buried gravel channels. Therefore, the configuration of the top of the shale was used to guide selection of apparent conductivity at the deepest differential depths. In parts of the study area, apparent conductivity and associated differential depth is located below the top of the shale (dark green and blue areas in fig. 8). In other parts of the study area, apparent conductivity and associated differential depth is above the top of the shale (yellow, orange, and pink areas in fig. 8). An iterative analysis of comparing differential depths and corresponding apparent conductivity values to Bearpaw Shale depth indicated the data with more than one-third of the depth section below the top of the shale yielded apparent conductivity values that overwhelmingly were affected by the shale conductivity. Therefore, differential depth extending below the top of the shallow aquifers yet no more than one-third of the depth section into the shale was selected to be within the relevant range that represents the shallow aquifers (fig. 9). For each electromagnetic frequency, apparent conductivity measured with the differential depth in the relevant range was used to represent the shallow aquifers (fig. 10). The distribution of apparent conductivity measured with the differential depth in the relevant range compared well with the distribution of dissolved-solids and chloride concentrations in groundwater from the shallow aquifers. 


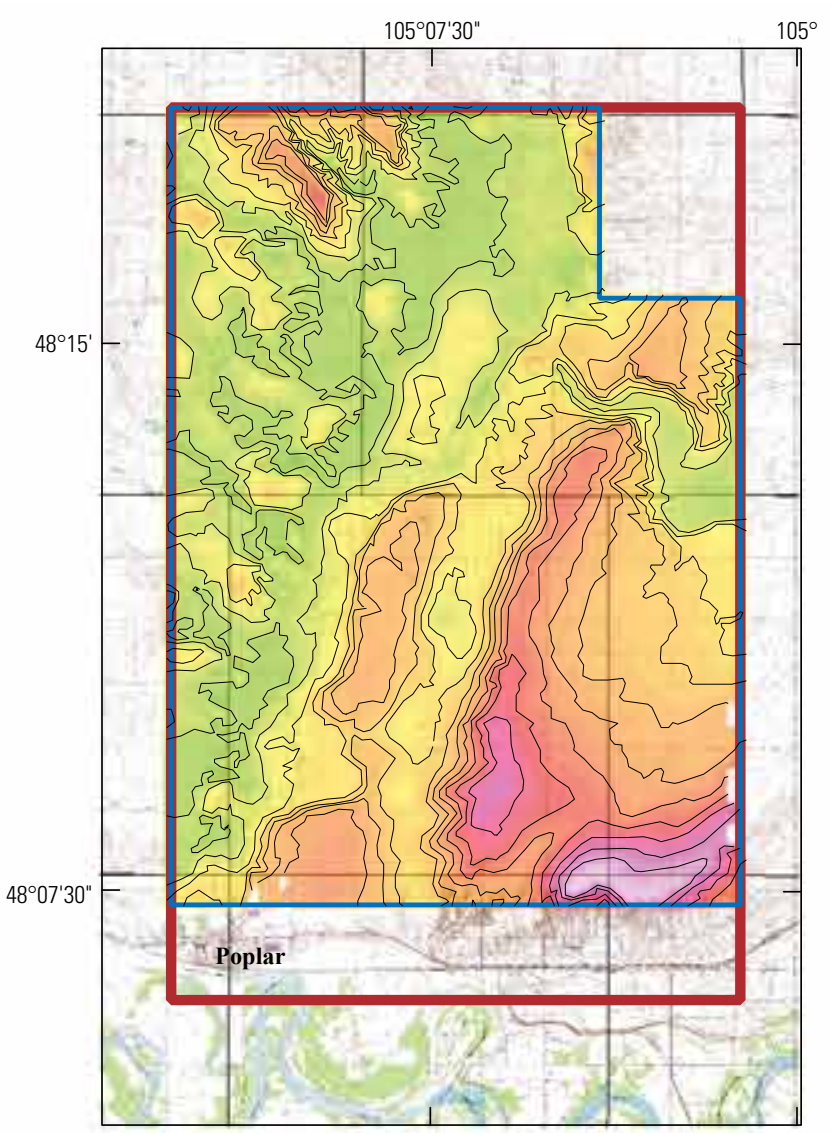

Electromagnetic frequency 140,000 hertz

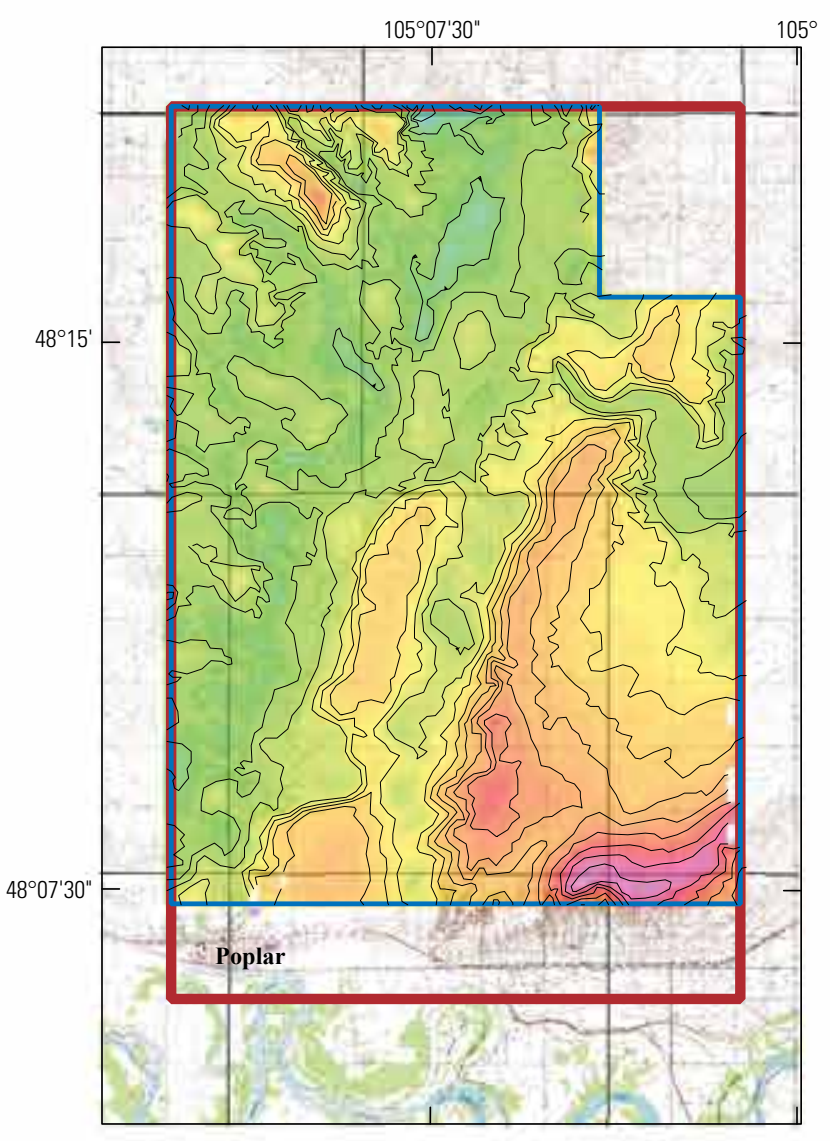

Electromagnetic frequency 8,200 hertz

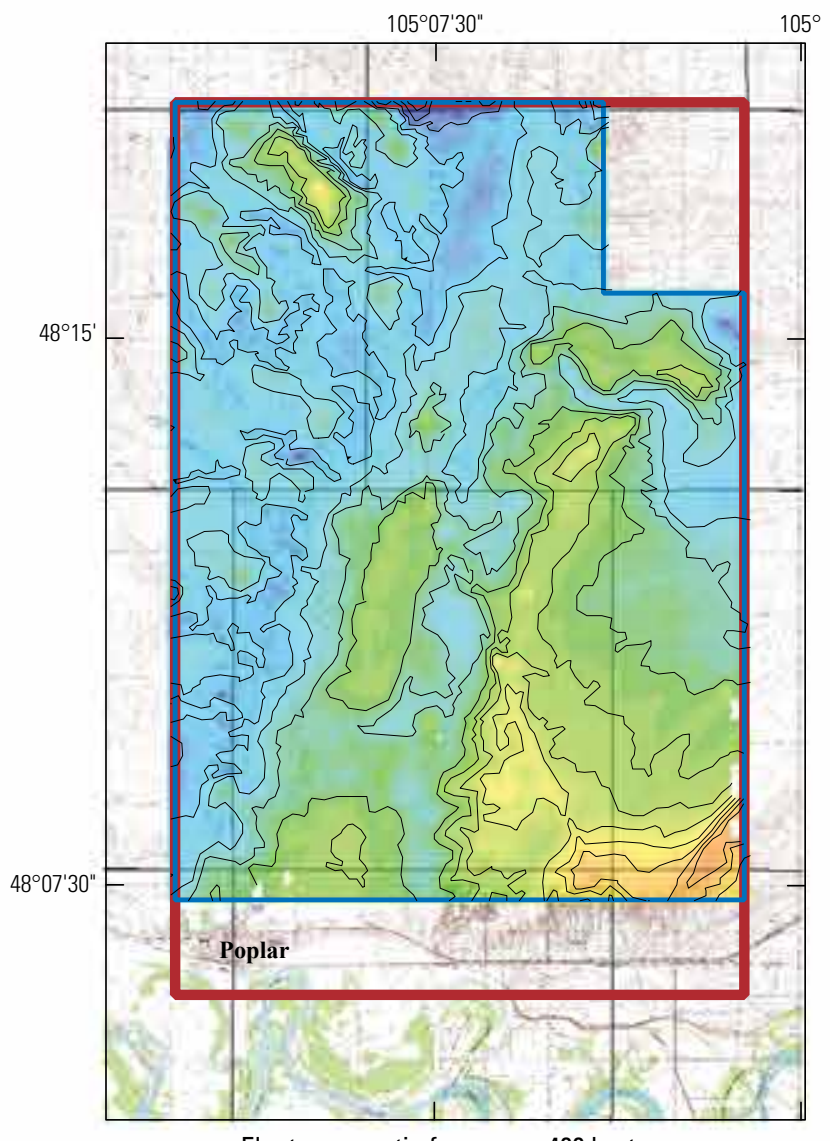

Electromagnetic frequency 400 hertz

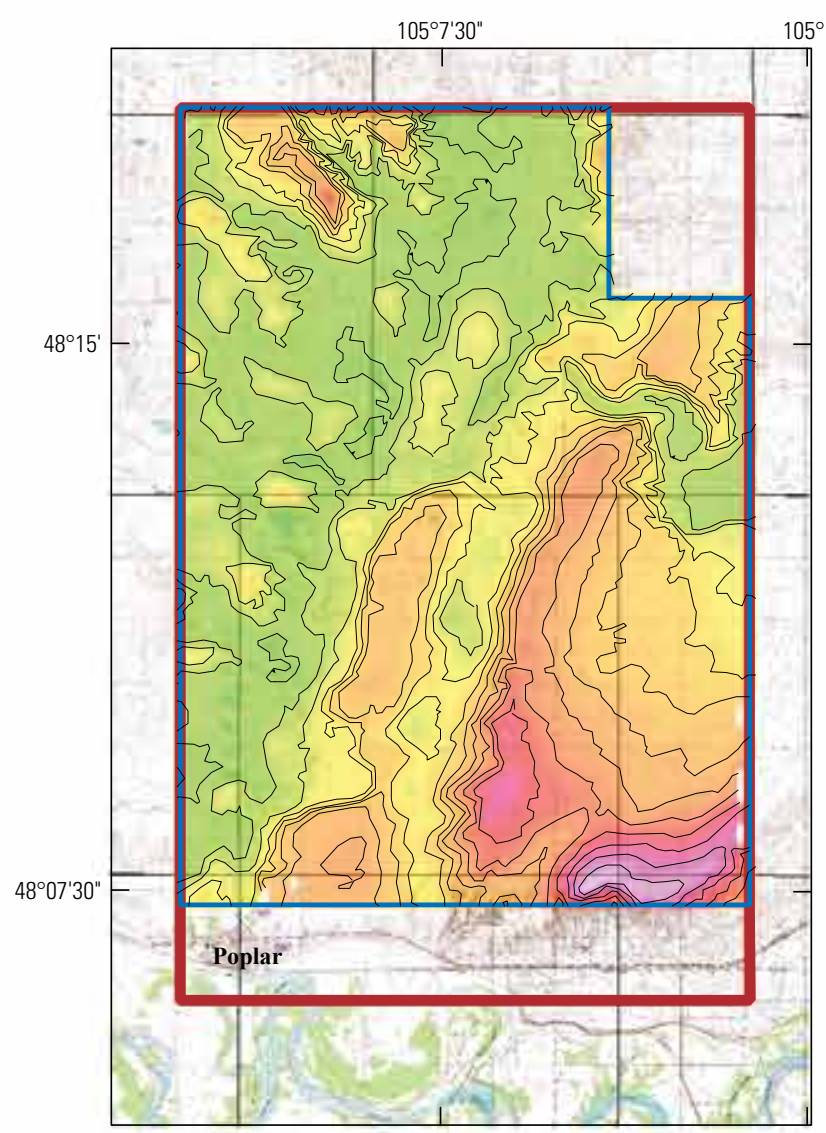

Electromagnetic frequency 40,000 hertz

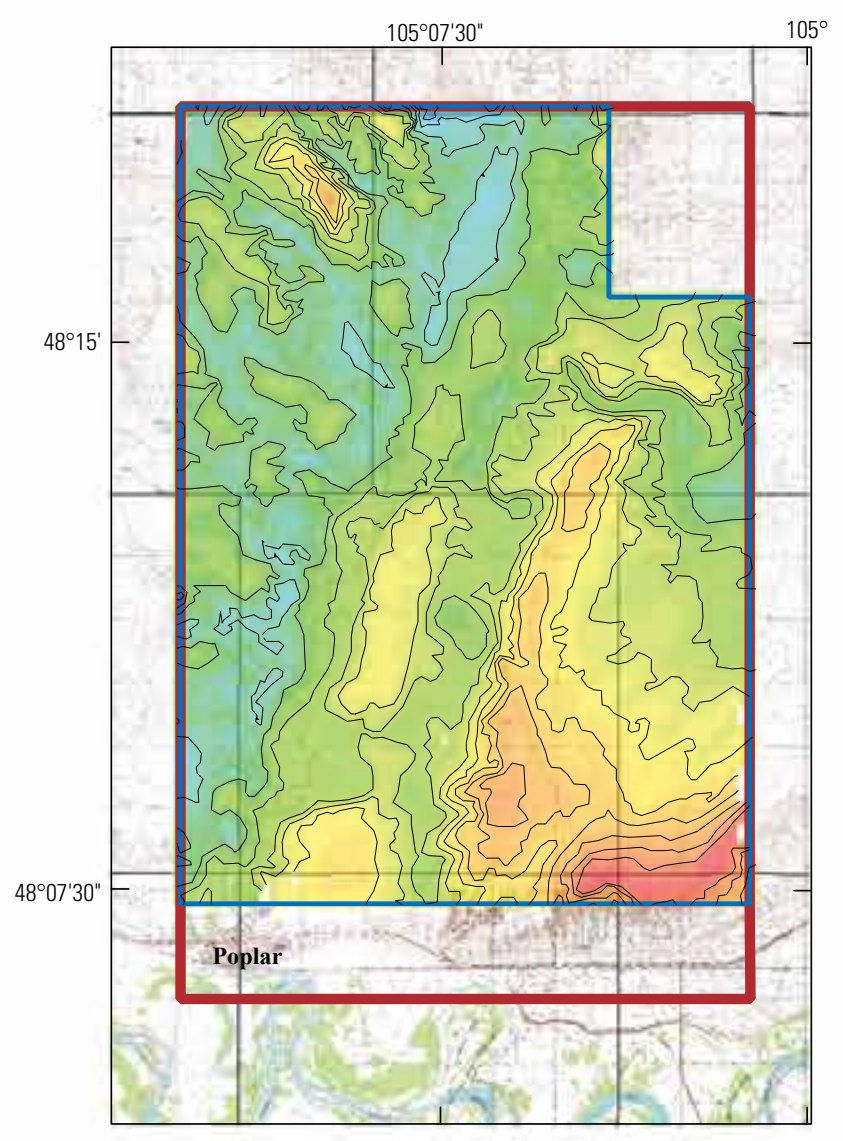

Electromagnetic frequency 1,800 hertz

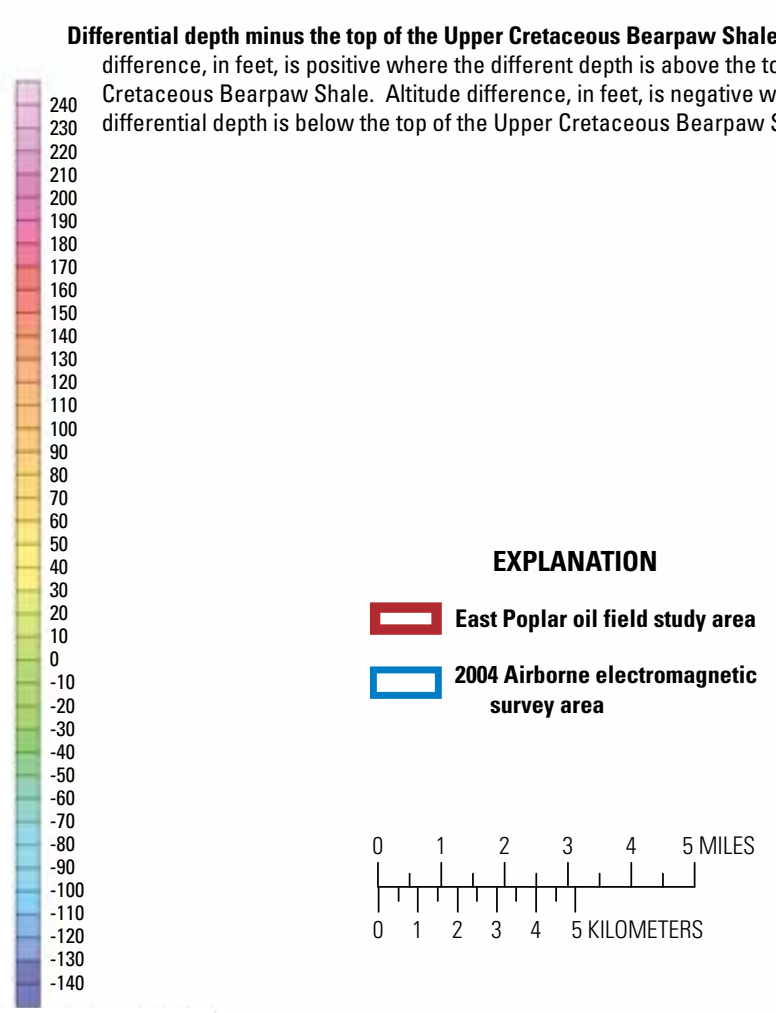

Base modified from U.S. Geological Survey Digital Raster Graphic (DRG) 1:24,000, 2002. Universal Transverse Mercator projection, Clarke 1866, Zone 13 , North American Datum of
Vertical Datum of 1988 (NAVD 88)

Figure 8. Altitude difference between the differential depth at selected electromagnetic frequencies and the top of the Bearpaw Shale, in and near the East Poplar oil field, 2004 Altitude difference, in feet, is positive where the differential depth is above the top of the Bearpaw Shale, and is negative where the differential depth is below the top of the Bearpaw 


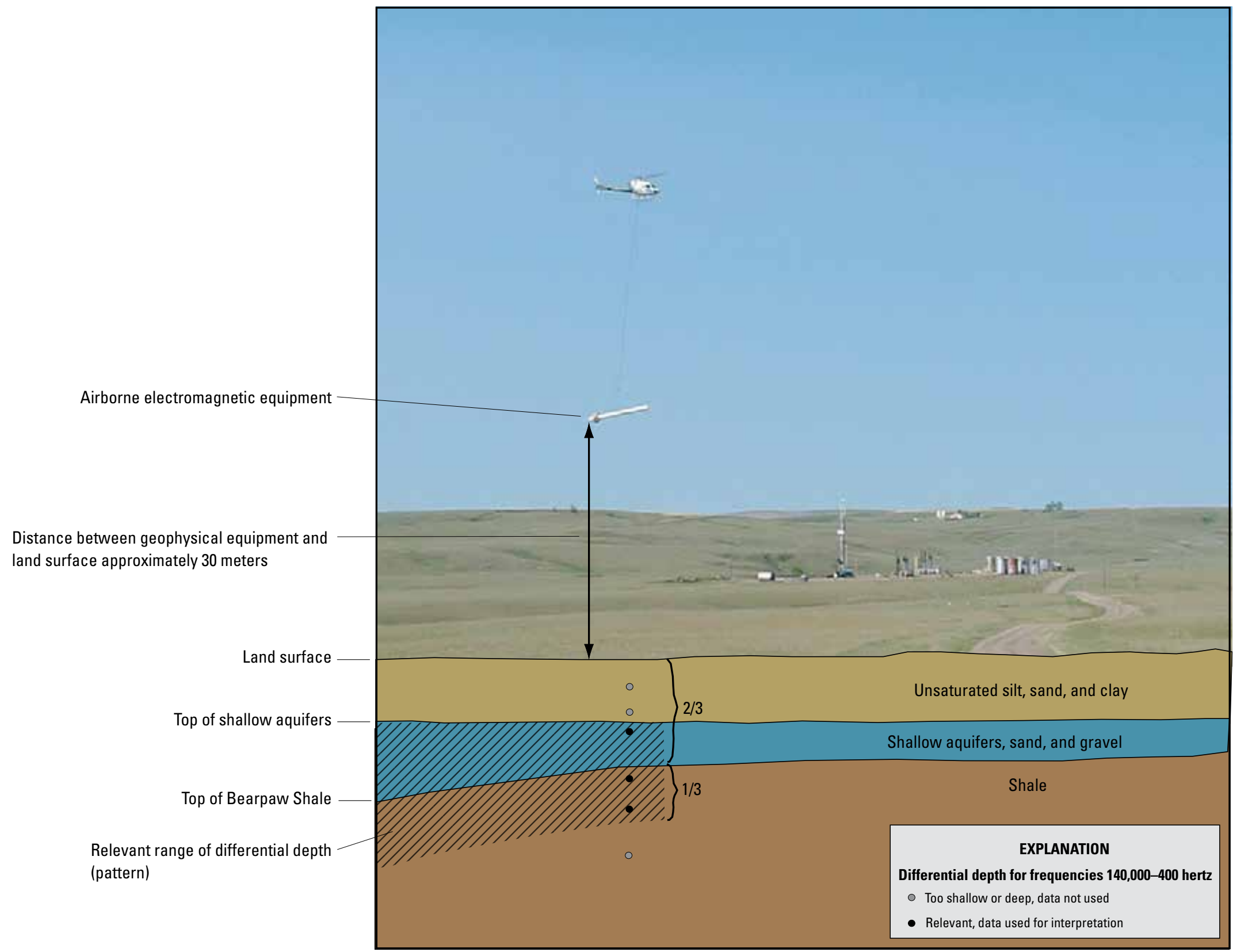

Figure 9. Generalized diagram showing the relevant range of differential depth, in and near the East Poplar oil field, 2004. The relevant range is bounded by the top of the shallow aquifers and does not extend more than one-third of the depth section into the Bearpaw Shale. Apparent conductivity measured with the differential depth in the relevant range was used in interpretations. 


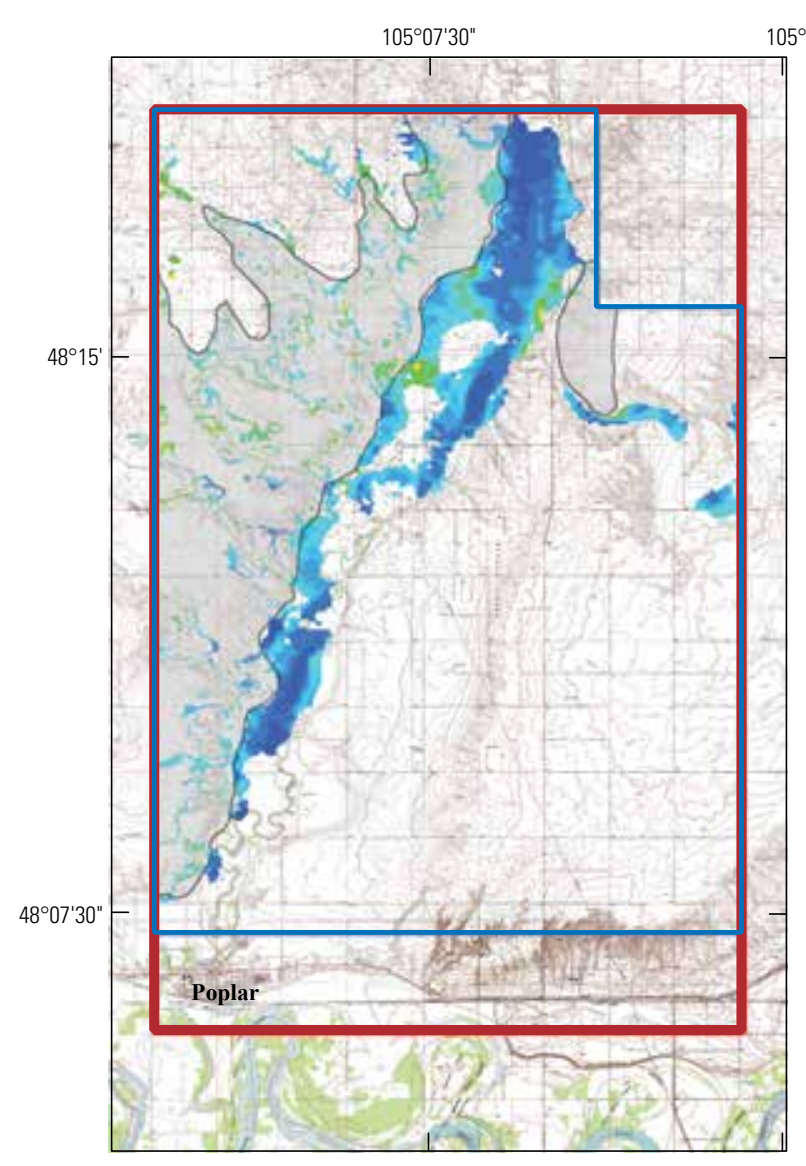

Electromagnetic frequency 140,000 hertz

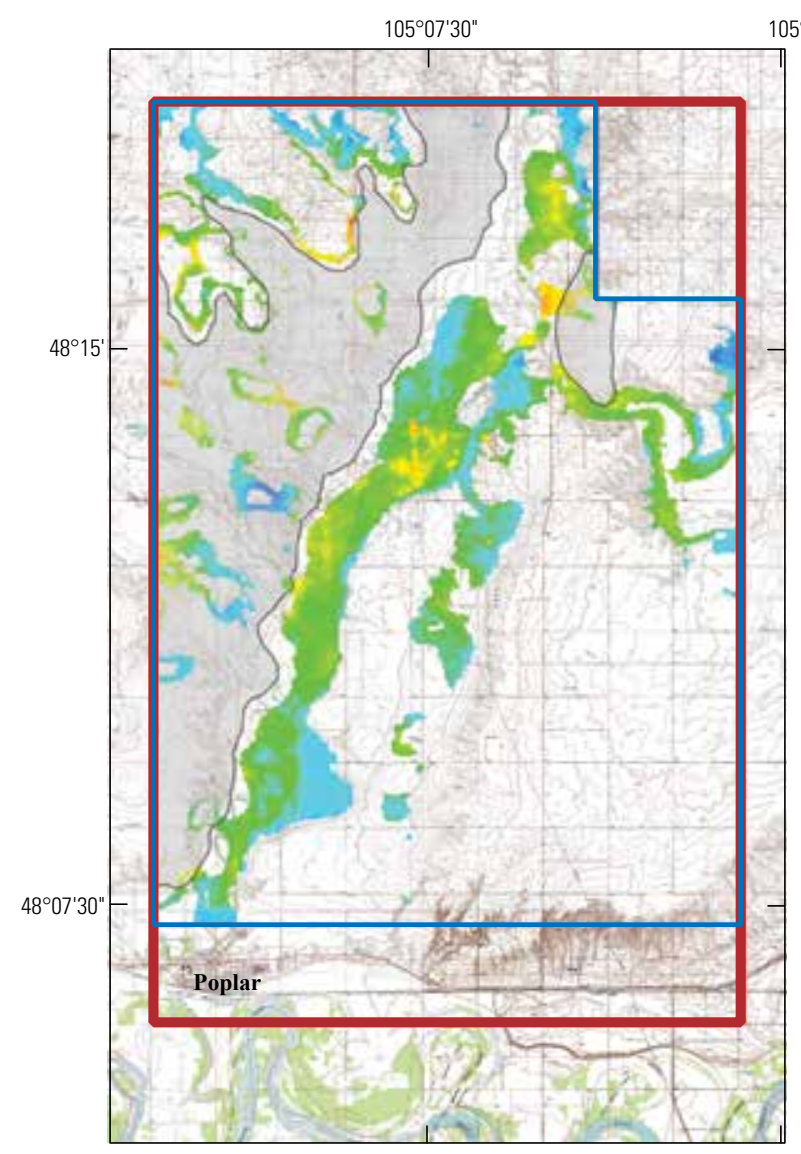

Electromagnetic frequency 8,200 hertz

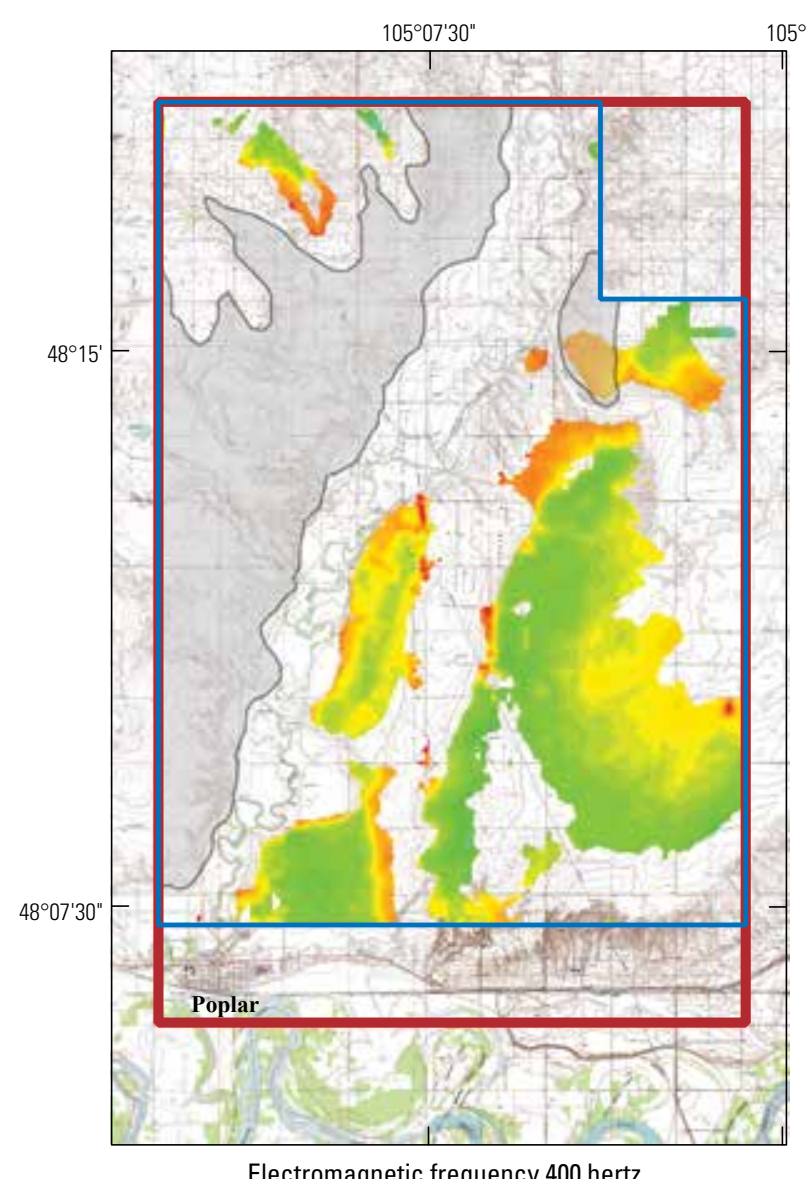

Electromagnetic frequency 400 hert

Base modified from U.S. Geological Survey Digital Raster Graphic (DRG)

1:24,000, 2002. Universal Transverse Mercator projection, Clarke 1866,
Zone 13 North American Datum of 1927 (NAD 27), and North American

Zone 13, North American Datum of 1927 (NAD 27), and North American

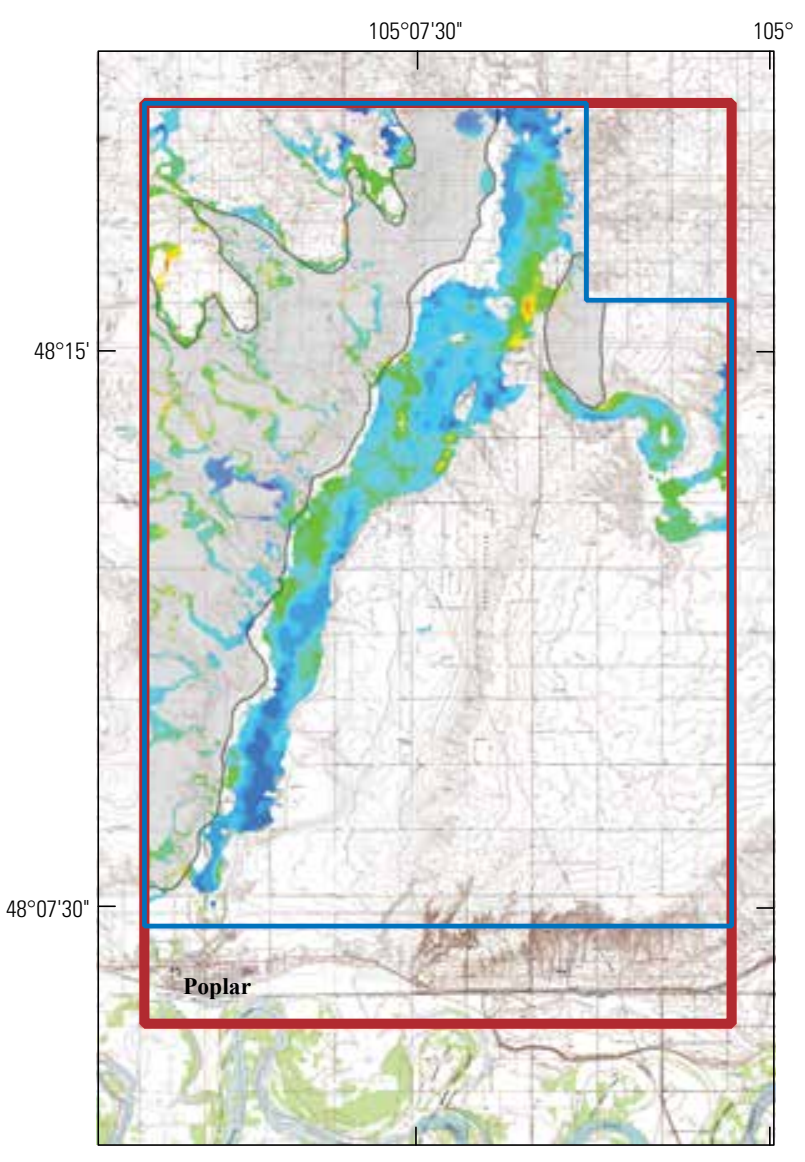

Electromagnetic frequency 40,000 hertz

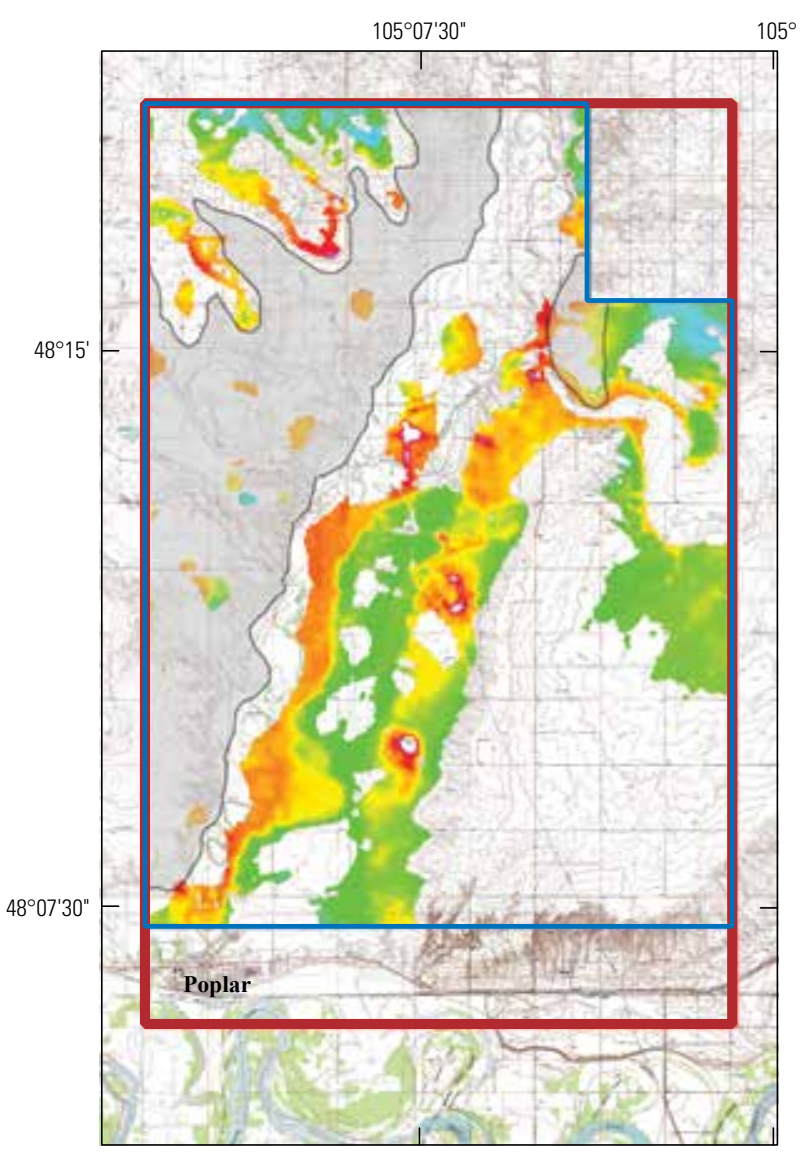

Electromagnetic frequency 1,800 hertz

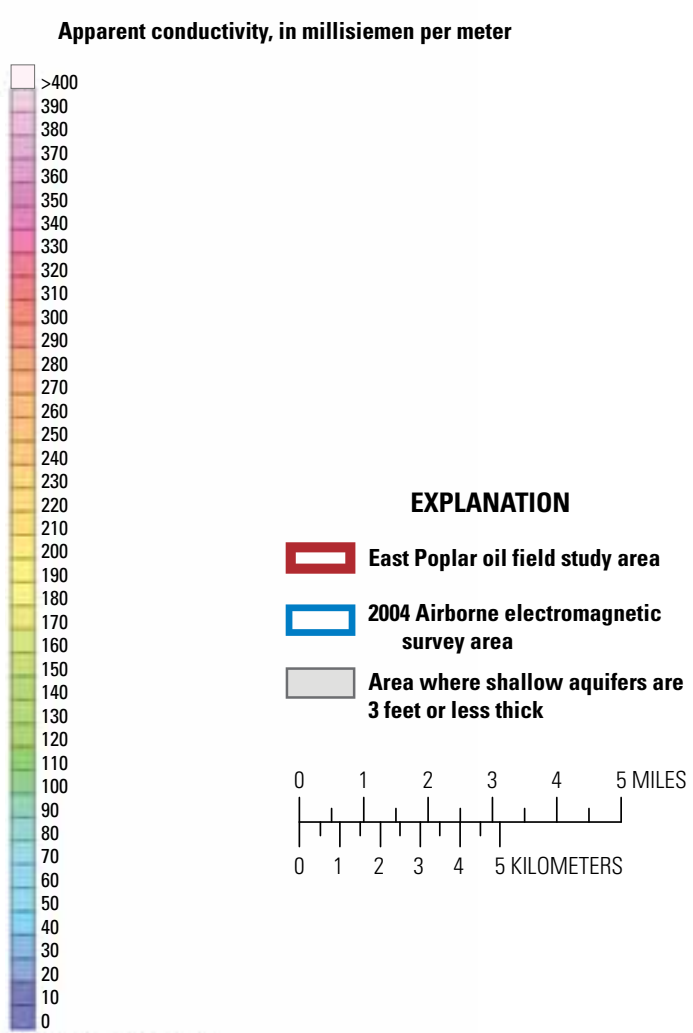

Figure 10. Apparent conductivity measured with the differential depth in the relevant range of the shallow aquifers, in and near the East Poplar oil field, 2004. The relevant range of differential depth is described in figure 9 . 


\section{Delineation of Brine Contamination in and near the East Poplar Oil Field, Fort Peck Indian Reservation}

Interpretation of the 2004 airborne electromagnetic data also required dividing the study area into six subareas (fig. 11) based on similar geologic properties and thickness of the unsaturated units and shallow aquifers that overlie the Bearpaw Shale (table 5). Terrace 1 is located in the northwestern part of the study area (fig. 11) and generally has the highest land-surface altitude within the study area. This is the only subarea that the geologic units above the Bearpaw Shale include not only Quaternary deposits, but also Tertiary and Upper Cretaceous units. Shallow aquifers in terrace 1 are thin and compose only a minor (generally $<20$ percent) part of the sediments overlying the Bearpaw Shale. Terrace 2 is in the eastern half of the study area (fig. 11) and land-surface altitude is slightly lower than terrace 1 . The sediments overlying the shale in this part of the study area include Quaternary glacial deposits and Wiota Gravel. Shallow aquifers in terrace 2 are thicker than terrace 1 , but still compose a minor (generally $<20$ percent) part of the sediments that overlie the Bearpaw Shale. Slims Coulee is in the northeastern part of the study area (fig. 11), is surrounded by terrace 2, and land-surface altitude is lower than terrace 2. In Slims Coulee, the primary geologic units above the Bearpaw Shale are Quaternary fan alluvium and colluvium. Shallow aquifers in Slims Coulee generally are less than $10 \mathrm{ft}$ thick and compose less than one-third of the materials above the Bearpaw Shale, except in a small area where the shallow aquifers are $20 \mathrm{ft}$ thick and compose more than half of the materials above the Bearpaw Shale. Terrace 3 is in the central part of the southern half of the study area (fig. 11), land-surface altitude is about the same as Slims Coulee and slightly lower than terrace 2, and Quaternary glacial deposits and Wiota Gravel overlie the shale. Shallow aquifers in terrace 3 are about as thick as terrace 2 , but generally compose almost one-third of the materials above the Bearpaw Shale. The zone of low hydraulic conductivity delineated by S.S. Papadopulos \& Associates, Inc. (2008) generally follows the boundary between terrace 3 and the ancestral Poplar River valley. The ancestral Poplar River valley is in the west-central part of the southern half of the study area (fig. 11) and land-surface altitude is lowest of all subareas. The altitude of the top of the Bearpaw Shale is lowest in the ancestral Poplar River valley subarea (fig. 7). Quaternary geologic units overlie the shale in the ancestral Poplar River valley. Shallow aquifers in the ancestral Poplar River valley are thick and compose about one-third of the materials above the Bearpaw Shale. The modern Poplar River valley is in the northeastern to southwestern parts of the study area (fig. 11) and land surface altitude is slightly higher than the ancestral Poplar River valley. This is the only subarea that contains only Quaternary alluvium and colluvium. Shallow aquifers in the modern Poplar River valley are thick and compose more than half to nearly all of the materials that overlie the Bearpaw Shale. 


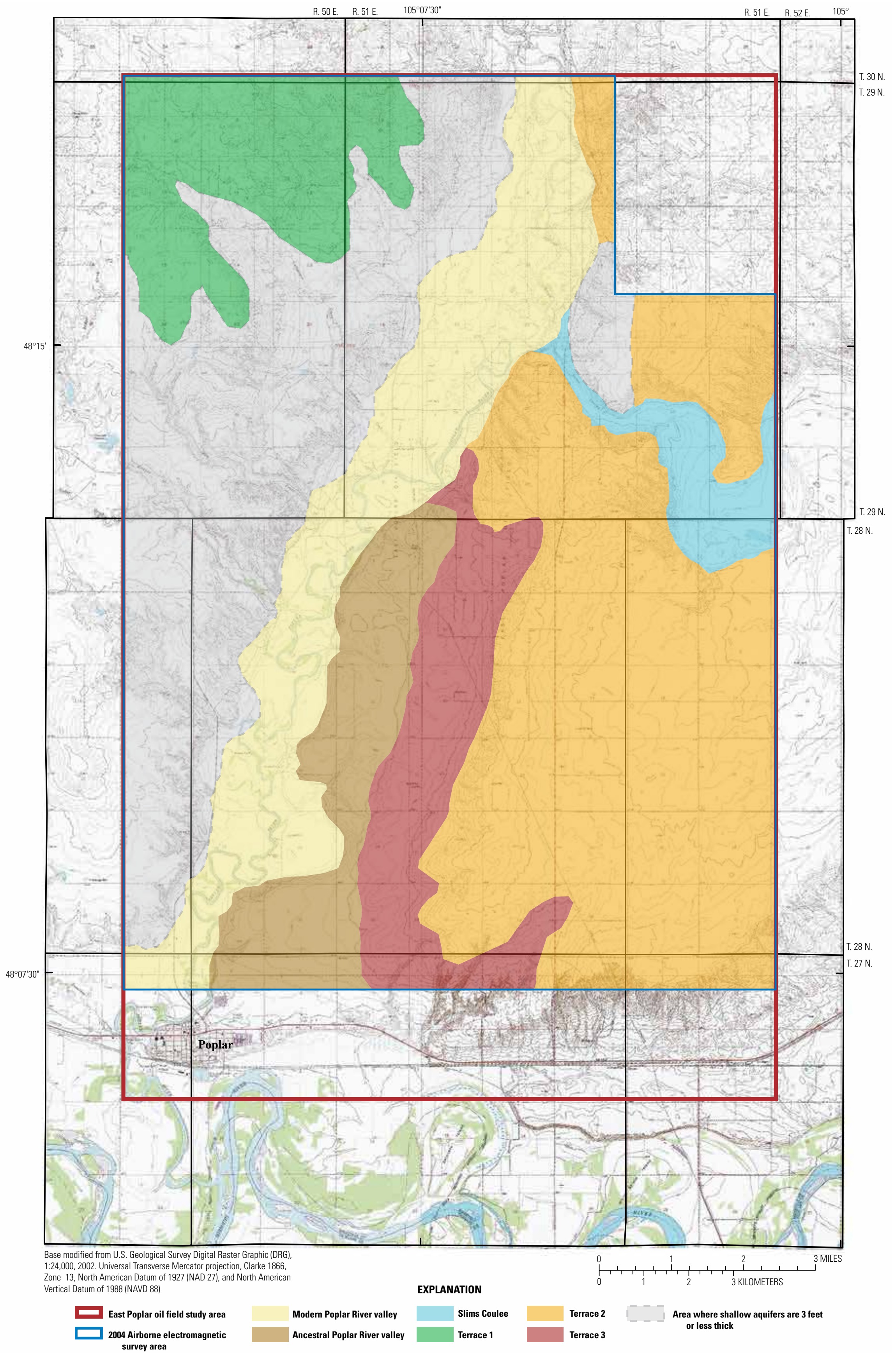


Table 5. General characteristics of six geologic subareas in and near the East Poplar oil field.

[Geologic unit: Qal, Alluvium (Quaternary); Qac, Fan Alluvium and Colluvium (Pleistocene and Holocene); Qt, Glacial till (Pleistocene); Qgo, Glacial outwash (Pleistocene); Qw, Wiota Gravel (Pleistocene); Qs, Sprole Silt (Pleistocene); Tfg, Flaxville Formation (Pliocene or Miocene); Tfu, Fort Union Formation (Paleocene); Khc, Hell Creek Formation (Upper Cretaceous); Kfh, Fox Hills Formation (Upper Cretaceous); ft, feet; <, less than]

\begin{tabular}{|c|c|c|c|c|c|c|c|}
\hline \multirow[b]{2}{*}{ Subarea } & \multirow[b]{2}{*}{ Location } & \multirow{2}{*}{$\begin{array}{l}\text { Land- } \\
\text { surface } \\
\text { altitude } \\
\text { (ft) }\end{array}$} & \multirow{2}{*}{$\begin{array}{l}\text { Altitude of } \\
\text { top of Upper } \\
\text { Cretaceous } \\
\text { Bearpaw } \\
\text { Shale (ft) }\end{array}$} & \multicolumn{4}{|c|}{$\begin{array}{c}\text { Primary geology and approximate thickness of units above } \\
\text { Upper Cretaceous Bearpaw Shale }\end{array}$} \\
\hline & & & & $\begin{array}{l}\text { Primary } \\
\text { geologic units }\end{array}$ & $\begin{array}{l}\text { Unsaturated } \\
\text { units } \\
\text { (ft) }\end{array}$ & $\begin{array}{l}\text { Shallow } \\
\text { aquifers } \\
\text { (ft) }\end{array}$ & $\begin{array}{l}\text { Com- } \\
\text { bined } \\
\text { (ft) }\end{array}$ \\
\hline Terrace 1 & $\begin{array}{l}\text { Northwestern part of study } \\
\text { area }\end{array}$ & $2,200-2,400$ & $2,160-2,360$ & Qt, Tfg, Tfu, Khc, Kfh & $<3-130$ & $0-10$ & $<3-140$ \\
\hline Terrace 2 & Eastern half of study area & $2,100-2,260$ & $2,000-2,120$ & Qd, Qt, Qgo, Qs, Qw & $20-220$ & $5-30$ & $40-240$ \\
\hline Slims Coulee & $\begin{array}{l}\text { Northeastern part of study } \\
\text { area }\end{array}$ & $2,060-2,100$ & $2,000-2,040$ & Q1, Qac, Qs, Qw & $<3-40$ & $0-20$ & $<3-60$ \\
\hline $\begin{array}{l}\text { Ancestral Poplar } \\
\text { River valley }\end{array}$ & $\begin{array}{l}\text { West-central part of southern } \\
\text { half of study area }\end{array}$ & $2,000-2,080$ & $1,890-1,960$ & Qd, Qt, Qac, Qw & $40-90$ & $5-50$ & $80-140$ \\
\hline $\begin{array}{l}\text { Modern Poplar } \\
\text { River valley }\end{array}$ & $\begin{array}{l}\text { Northeastern to southwestern } \\
\text { parts of study area }\end{array}$ & $1,960-2,020$ & $1,890-2,000$ & Qac, Qal & $<3-60$ & $<3-40$ & $<3-100$ \\
\hline
\end{tabular}

Areas of low, moderate, and high apparent conductivity were delineated (fig. 12) using a select range of values within each of the six geologic subareas. The location of water wells sampled within the study area and corresponding water type (appendix 5) also are shown in figure 12. Wells with sample results that span multiple years are represented in figure 12 by the water type nearest to 2004. Characteristics of the four water types defined in this study area are listed in table 4.

Water from wells completed in the geologic subareas with low apparent conductivity generally was Type 1 (uncontaminated). Low apparent conductivity areas are shaded blue in figure 12 and are delineated where measurements at one or more of the five electromagnetic frequencies (table 2) within the representative depth of the shallow aquifers are low (table 6). Water from wells in the geologic subareas with moderate apparent conductivity generally was Type 2 (moderately contaminated). Moderate apparent conductivity areas are shaded yellow in figure 12 and are delineated where measurements at one or more of the five frequencies measured within the representative depth of the shallow aquifers are moderate (table 6) and no measurements within the representative depth of the shallow aquifers are low. Water from wells in the geologic subareas with high apparent conductivity generally was Type 3 (considerably contaminated). High apparent conductivity areas are shaded dark pink in figure 12 and are delineated where apparent conductivity values at all five frequencies measured within the representative depth of the shallow aquifers are high (table 6). 


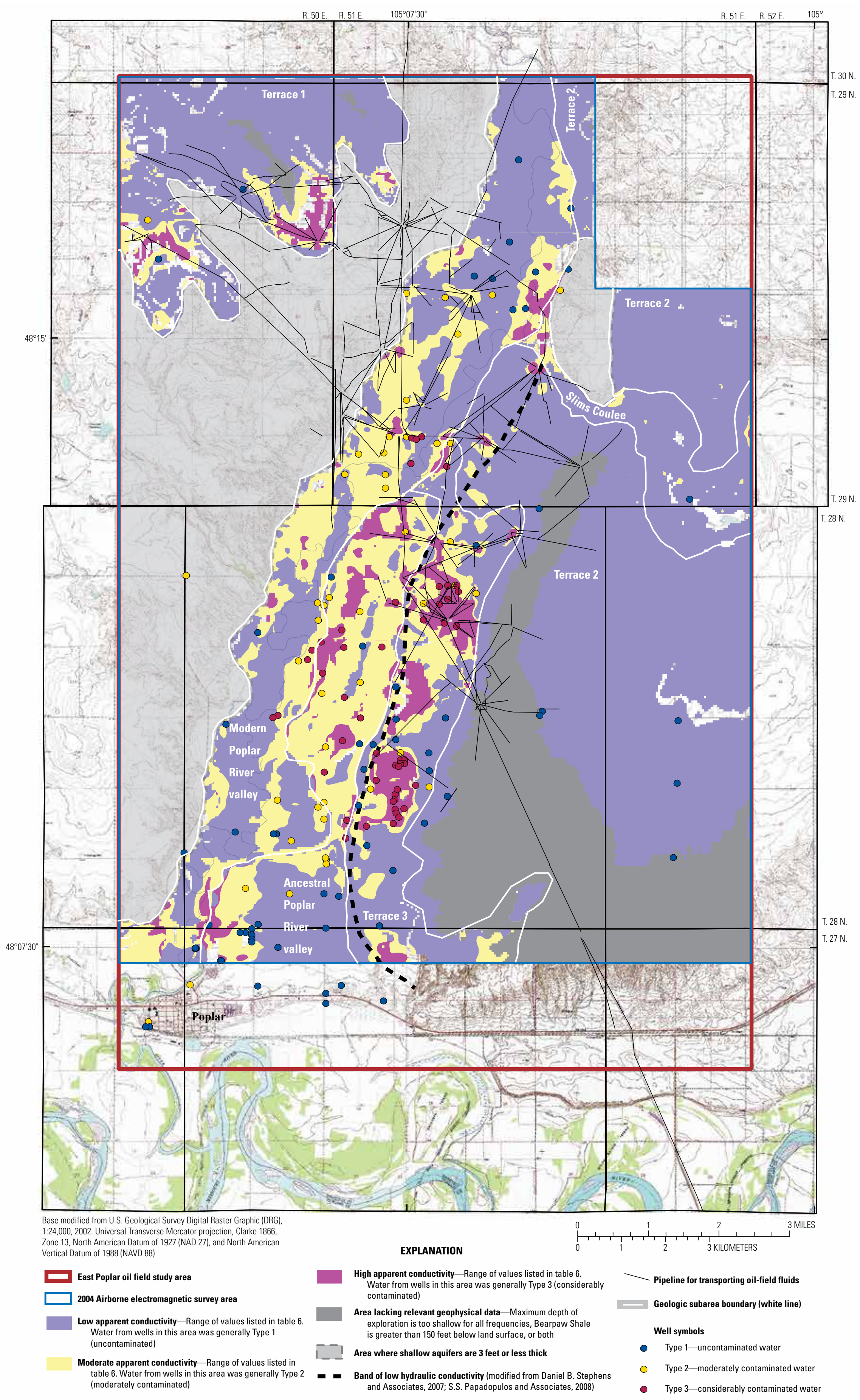

Figure 12. Areas of low, moderate, and high apparent conductivity in shallow aquifers, 2004, and types of water from wells in and near the East Poplar oil field. 


\section{Delineation of Brine Contamination in and near the East Poplar Oil Field, Fort Peck Indian Reservation}

Table 6. Range of values used to delineate areas of low, moderate, and high apparent conductivity in and near the East Poplar oil field, 2004.

$[\mathrm{mS} / \mathrm{m}$, millisiemens per meter; <, less than; >, greater than $]$

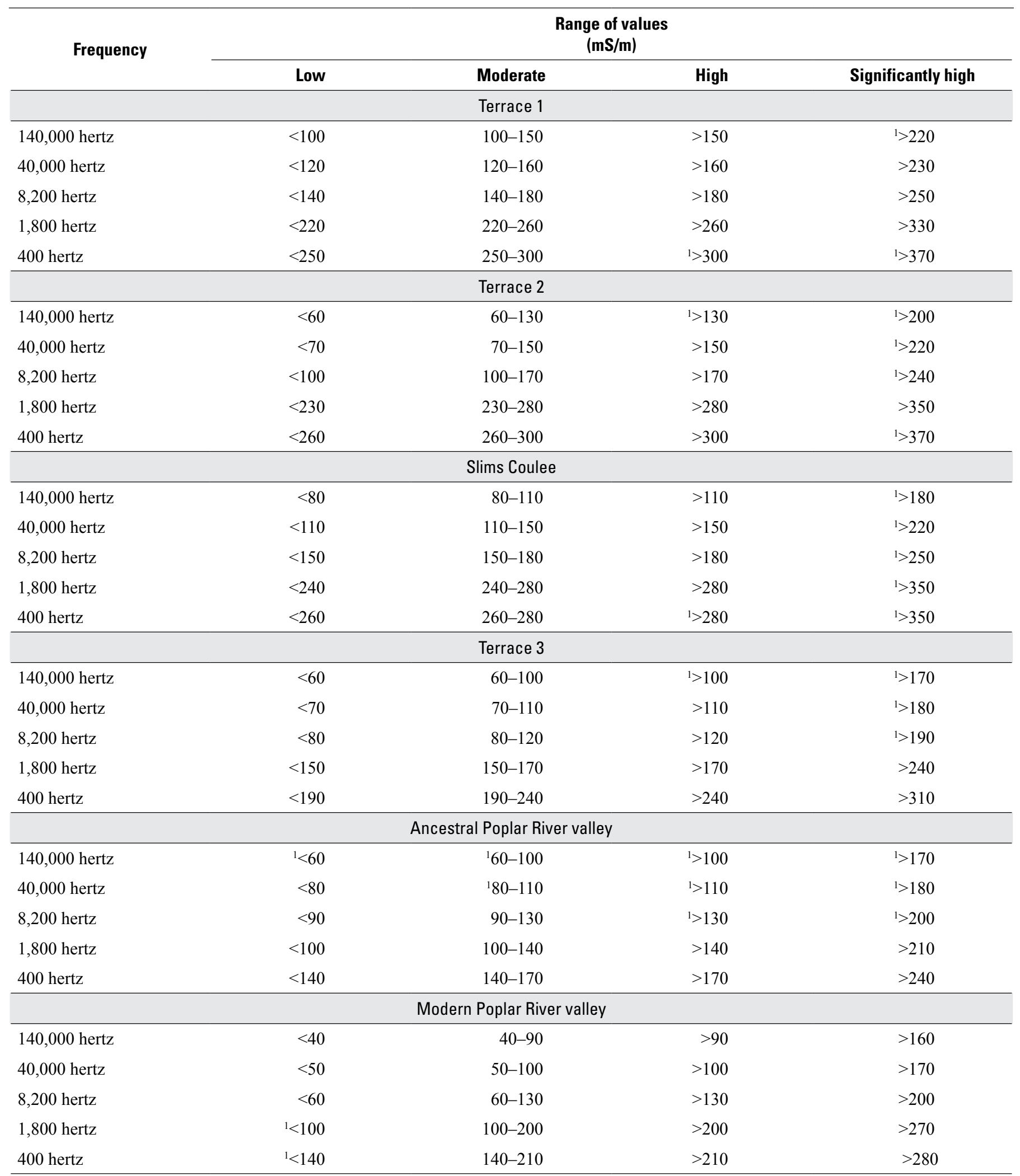

${ }^{1}$ No conductivity values in this range were measured in this subarea at this frequency. 


\section{Anomalies}

The relation between apparent conductivity and water quality is consistent throughout most of the study area (fig. 12); however, there are 13 anomalies where wells with water from a particular water type (Type 1,2, or 3) are not in or adjacent to the delineated area of corresponding apparent conductivity (low, moderate, or high apparent conductivity). The difference between water type and apparent conductivity exists at these 13 areas most likely because factors other than water quality can affect apparent conductivity values in the following ways: (1) delineation might be less accurate at the edges of the airborne electromagnetic survey grid; (2) delineation of water type is based on ranges of chloride and dissolved-solids concentrations, which overlap particularly at lower values; (3) clay and water electrical conductivity at low values can cause anomalous responses; and (4) areas of subsurface high dissolved solids may not be large enough or have enough volume to produce an area of high apparent conductivity or small areas may be between flight lines.

In terrace 1 , there is one anomaly in the relation between apparent conductivity and water quality (fig. 12). In sec. 10, T. 29 N., R. 50 E., water collected from well M-72 (fig. 5) during 2004 was Type 2; however, the well is completed in an area of low apparent conductivity. There is no well-completion information available for this domestic well, which can be useful in determining a relation between the apparent conductivity at representative differential depth and the water quality. Despite the lack of well-completion information, this well is near $(<0.1 \mathrm{mi})$ an area of delineated moderate apparent conductivity as expected for Type 2 water.

In terrace 1, borehole data logged in sec. 15, T. 29 N., R. 50 E. at well MSCA-4 (fig. 5) demonstrates the complexity of interpretation. High conductivity was measured with borehole and airborne electromagnetic methods, in a shallow (between 10-15 ft) zone and a deep (between 35-50 ft) zone (fig. 13A); however, water from this well is Type 1 (appendix 5). High conductivity in the shallow zone could be attributed to weathered shale that is reported from 10-17 ft. High conductivity in the deep zone could be attributed to the Bearpaw Shale that is reported from $18-53 \mathrm{ft}$ or from water at
$35 \mathrm{ft}$ below land surface with high dissolved-solids concentration $(41,100 \mathrm{mg} / \mathrm{L})$. Additional geochemical results could help identify the source of the high dissolved-solids concentration and additional geophysical logging in nearby monitoring wells could help confirm the sources of high apparent conductivity.

In terrace 2, there were no anomalies. Water from all seven wells in terrace 2 were Type 1 and the entire subarea had low apparent conductivity.

In Slims Coulee, there were no anomalies. Water from the only well completed in this subarea was Type 1 and most of the subarea had low apparent conductivity.

In terrace 3, there are two anomalies in the relation between apparent conductivity and water quality (fig. 12). The first anomaly is in the southern part of sec. 22 , T. $28 \mathrm{~N}$., R. 51 E., and exists for an area at well PNR-22 (fig. 5). Water from this well was Type 2; however, the well is located in an area of low apparent conductivity. The lithologic log for this well indicates that the saturated deposits are about 80-100 $\mathrm{ft}$ deep and composed of well-graded gravel and sand. The borehole log for PNR-22 (fig. 13B) shows an anomalous high conductivity zone about $25 \mathrm{ft}$ deep in the unsaturated deposits, and lower conductivity in the saturated deposits. The airborne electromagnetic data (red dots in fig. 13) are similar to the borehole electromagnetic data for well PNR-22, but are a magnitude greater than the borehole electromagnetic data for USGS93-3 (fig. 13C). The difference at USGS93-3 likely is due in part to scale because the airborne electromagnetic method measures a volume of tens of meters whereas the borehole electromagnetic method measures in meters or even centimeters. It is likely that the Type 2 water is confined in an area that probably is too thin, too narrow, or both, to delineate with the airborne electromagnetic data. The second anomaly is in the western part of sec. 22, T. 28 N., R. 51 E., and exists for wells PNR-25 and PNR-26 (fig. 5) that are screened only in the upper part of the shallow aquifers. Water from these wells was Type 2; however the wells are located in an area of high apparent conductivity. Adjacent wells are screened in the lower part of the shallow aquifers and water from these wells was Type 3 , indicating likely vertical stratification of brine contamination in the shallow aquifers. 
A $\begin{array}{lc}\text { Well name } & \text { MSCA-4 } \\ \text { Date logged } & 08 / 08 / 2004\end{array}$

Conductivity, in millisiemens per meter

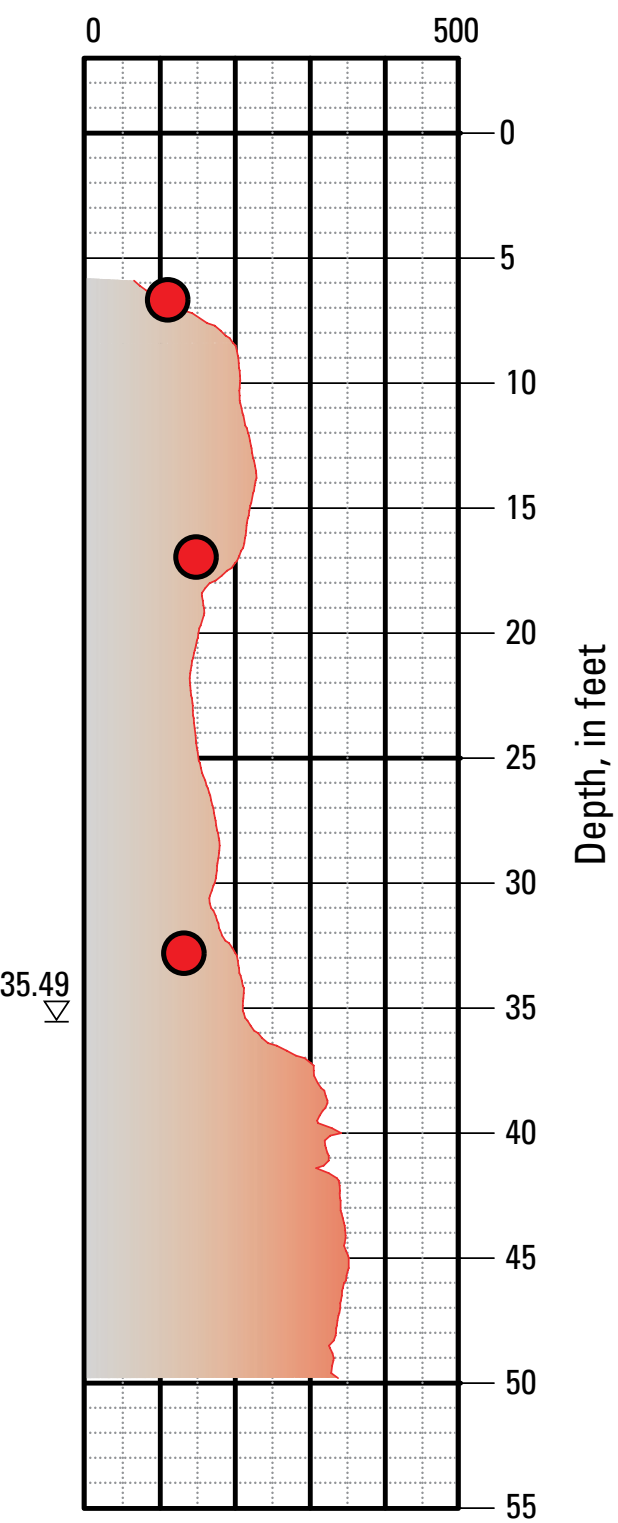

B

Well name PNR-22 Date logged $\quad 08 / 13 / 2004$

Conductivity, in millisiemens per meter

0

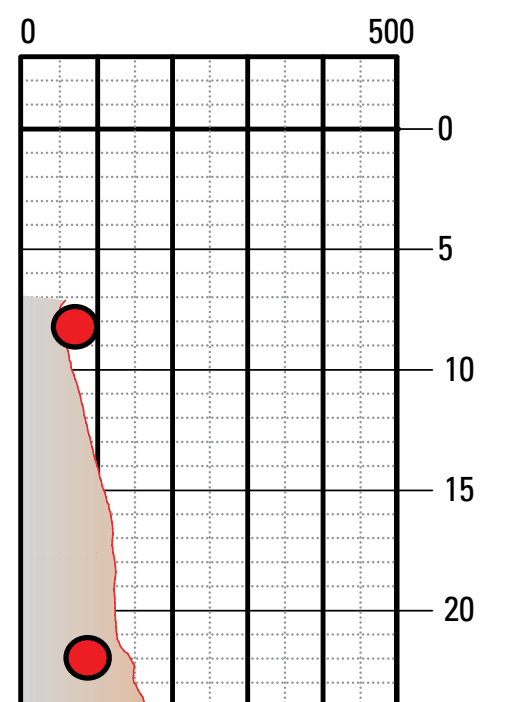

80.81

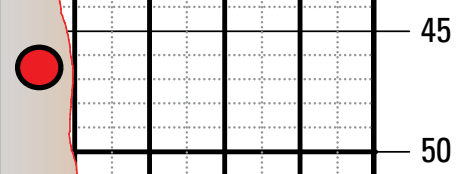

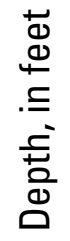

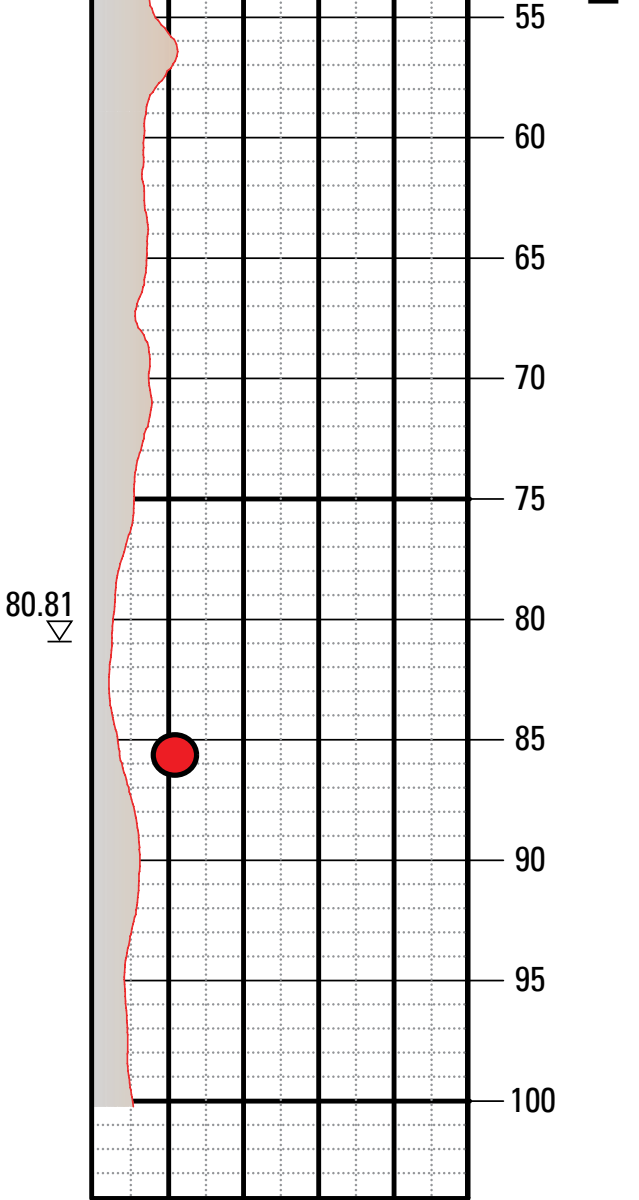

C

Well name USGS93-3

Date logged $\quad 08 / 07 / 2004$

Conductivity, in millisiemens per meter

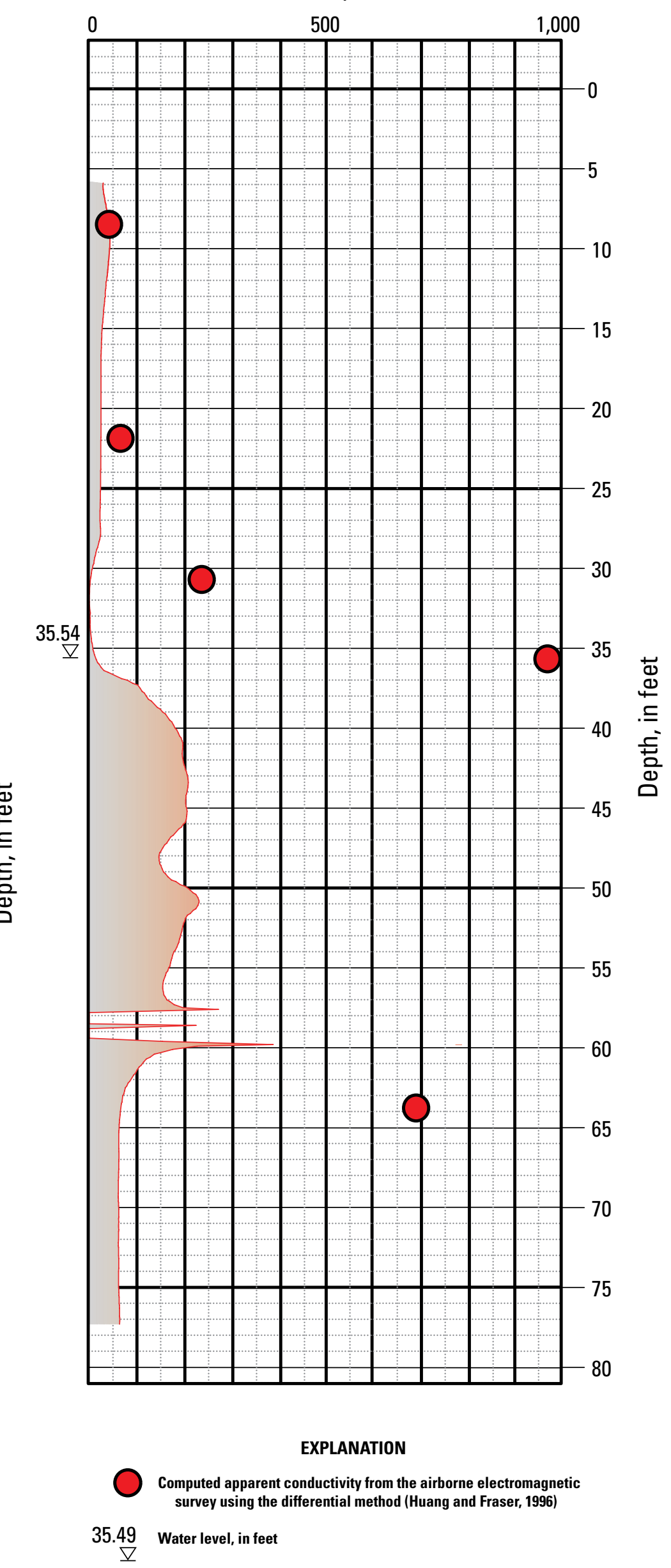

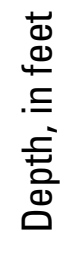

Figure 13. Borehole electromagnetic logs and airborne electromagnetic measurements at selected sites from $A$, terrace 1; and $B$ and $C$, terrace 3. Large red dots on conductivity logs are apparent conductivity from the airborne electromagnetic survey computed using the differential method. 
In the ancestral Poplar River valley geologic subarea, there are four anomalies in the relation between apparent conductivity and water quality (fig. 12). The first anomaly is in sec. 3, T. 28N., R. 51 E., and exists for an area of high apparent conductivity that contains well MOC-15. Water from this well was Type 2 in 2001. This anomaly could be due to the lack of water analyses from this well during 2004. The second anomaly is where the most recently collected water from wells in a moderate apparent conductivity area was near the range division between Type 2 and Type 3 designation. In secs. 9, 16, and 21, T. 28 N., R. 51 E., water from wells MOC-8, M-18, and PNR-9 (fig. 5) contained chloride concentrations as much as $6,010 \mathrm{mg} / \mathrm{L}$. Water from wells MOC-8 and M-18, sampled in 2001 and 2003 contained chloride and dissolved-solids concentrations slightly above the designated range for Type 2. Water sampled from PNR-9 during 2004 (the same time period as the airborne electromagnetic survey) was Type 2 and became Type 3 during 2007. Thus, the airborne electromagnetic data can be used to map the higher conductivity in general but not at the same site-specific resolution as monitoring-well data. The third anomaly is in sec. 32, T. 28 N., R. 51 E., and exists for an area at well USGS09-3 (fig. 5). This well is in an area of low apparent conductivity; however, water from this well during 2009 was Type 2. Water from nearby well LAW-M05 was Type 1 during 2002-04 and Type 2 during 2005-09, whereas chloride concentrations increased from 106 to $551 \mathrm{mg} / \mathrm{L}$ during 2002-09. It is likely that water at the site for well USGS09-3 was also Type 1 during 2004. The fourth anomaly is in sec. 5 and 6, T. 27 N., R. 51 E., and sec. 6, T. 27 N., R. 51 E., and exists in areas that contain M-65, M-67, USGS06-7, USGS06-8, LAW-M08, and LAW-M06 (fig. 5). These six wells are in areas of moderate and high apparent conductivity; however, water from these wells was Type 1. Despite being Type 1 water, chloride concentrations in samples from three of the wells (M-67, LAWM08, LAW-M06) are increasing steadily with time. This might be an area of poorly sorted gravel that responds slowly to brine-plume migration. Hydraulic characteristics determined for USGS06-7 indicate that it might be completed in a poorly connected channel and both wells might be poorly connected with nearby high conductivity areas.

In the modern Poplar River valley, there are five areas where the relation between apparent conductivity and water quality differ (fig. 12). In secs. 10, 15, 16, and 21, T. 29 N., R. 51 E., water from wells M-49, M-50, M-52, M-54, W-8, and USGS92-14 (fig. 5), which are located in areas of moderate and high apparent conductivity, was Type 1 with chloride concentrations less than $34 \mathrm{mg} / \mathrm{L}$. As described by Thamke and Craigg (p. 20, 1997), the conductive Bearpaw Shale is shallower in this area than in other areas and likely affects the apparent conductivity values. A small volume of water obtained from well USGS06-6 (fig. 5), located on the east side of this anomaly, was Type 2; however, the lithology for this well and the geology mapped near this well indicate that shallow aquifers are not present and the Bearpaw Shale is near the land surface. The second anomaly in the modern
Poplar River valley is in the northern part of secs. 20 and $21 \mathrm{~T}$. 29 N., R. 51 E. and exists for wells W-6 and W-9 (fig. 5). Both wells are in low apparent conductivity areas, but adjacent to a moderate apparent conductivity area. Water collected during the 1980s from both wells was Type 2 . This lack of correlation could be due to no recent water analyses from these wells. The third anomaly is in the northwest quarter of sec. 32, T. 29 N., R. 51 E., and exists for wells USGS82-12, USGS82-14, and USGS92-11 (fig. 5). All three wells are located in or adjacent to moderate apparent conductivity, yet water from these three wells was Type 3 with chloride concentrations greater than 14,000 (collected in 1982 and 1993). A borehole log from USGS92-11 (Smith and others, 2014) indicates moderately high conductivity similar to the airborne response. This anomaly could be due to the lack of recent water analyses from these three wells. Nearby wells were Type 3 in the 1980 s and 1990s, but all the nearby wells that were sampled again in the 2000s contained water that had become Type 2 . More recent analyses of water from the wells in this anomaly likely could indicate that the water is Type 2, which would agree with the delineation of moderate conductivity from the airborne survey and borehole logging. The fourth anomaly is on the east side of the modern Poplar River valley in sec. 17, T. 28 N., R. 51 E., and exists for wells M-19, M-22, M-80, and USGS09-6 (fig. 5). All four wells are in moderate apparent conductivity areas; however, water from these wells was Type 3. Domestic wells M-19 and M-22 are near $(<0.1 \mathrm{mi})$ an area of high apparent conductivity and according to the lithologic logs are completed in gravel. These wells might be connected by a gravel channel too narrow to map in detail with the airborne survey. Domestic well M-80 and monitoring well USGS09-6 were first sampled during 2009; if water samples were collected during the same time period as the 2004 airborne electromagnetic survey, the correlation might have been stronger. The fifth anomaly is in sec. 29 , T. 28 N., R. 51 E., and exists for well LAW-M04 (fig. 5). This well is in an area of low apparent conductivity; however, water from this well during 2002-08 was Type 2 . This well is near $(<0.1 \mathrm{mi})$ an area of moderate apparent conductivity and might be in a gravel channel too narrow to map accurately from the airborne electromagnetic data.

\section{Delineation of Brine Contamination}

The water-quality data collected from existing wells confirm the presence of brine contamination in the shallow aquifers in and near the East Poplar oil field; however, the distribution of the wells alone was insufficient to delineate brine contamination. To determine lateral and vertical extent of brine contamination, data from the 2004 airborne electromagnetic survey were interpreted in conjunction with water-quality data collected through 2009 for existing wells and wells that were drilled subsequent to the airborne electromagnetic survey. Water type nearest to 2004 was selected to represent wells with multiple water types. The magnitude of 
brine contamination was calculated using aquifer thickness and porosity in areas of confirmed and possible contamination. The movement of brine contamination was interpreted from groundwater hydraulic gradients and historical geophysical and groundwater-quality information. The specific source areas of brine contamination were determined from apparent conductivity data.

\section{Lateral Extent}

The estimated lateral extent of brine contamination in the shallow aquifers is as much as $17.9 \mathrm{mi}^{2}$ (fig. 14). This extent is within the boundary of the 2004 airborne electromagnetic survey and is estimated on the basis of water-quality data collected through 2009 and moderate and high apparent conductivity delineation throughout the study area in figure 12. Small parts of areas delineated as low apparent conductivity in figure 12 that contain one of more wells that produce moderately contaminated (Type 2) water are considered small confirmed areas of moderately (Type 2) contaminated groundwater in figure 14. Areas delineated as moderate or high apparent conductivity in figure 12 that contain one or more wells that produce moderately or considerably contaminated (Type 2 or Type 3) water are considered confirmed areas of moderately or considerably (Type 2 or Type 3 ) contaminated groundwater in figure 14. Areas delineated as moderate or high apparent conductivity in figure 12 that do not contain water wells are considered possible areas of moderately or considerably (Type 2 or Type 3) contaminated groundwater in figure 14 . Small parts of or entire areas delineated as moderate or high apparent conductivity in figure 12 that contain one or more wells that produce uncontaminated (Type 1) water are considered uncontaminated areas in figure 14.

The 2004-09 lateral extent of $17.9 \mathrm{mi}^{2}$ differs from the early 1990s lateral extent of $12.4 \mathrm{mi}^{2}$ (Thamke and Craigg, 1997). Although the fundamental methods of data interpretation are similar for determining the lateral extent, the additional data available for the 2004-09 lateral extent provided a greater level of detail that was not available in the early 1990s. Therefore, lateral extent between the early 1990s and 2004-09 should be compared only in a general manner.

The collective lateral extent of confirmed moderately contaminated water in the shallow aquifers is $10.4 \mathrm{mi}^{2}$ (areas shaded dark orange in fig. 14). The only confirmed moderately contaminated plume in terrace 1 (fig. 14) is located in the southwest part and has an area of $0.5 \mathrm{mi}^{2}$. Water from a privately owned well (M-72) was moderately contaminated in 2004 with a chloride concentration of $350 \mathrm{mg} / \mathrm{L}$; this well is used for limited domestic purposes. This well likely is completed in the Upper Cretaceous Hell Creek Formation and Fox Hills Sandstone; however, well-depth information and lithologic log are not available to confirm the geologic formation. The largest confirmed moderately contaminated plume has an area of $6.3 \mathrm{mi}^{2}$ and is located in terrace 3, the ancestral Poplar River valley, and the modern Poplar River valley. Water collected from nearly 40 privately owned and monitoring wells completed at various depths throughout this plume was moderately contaminated and contained chloride concentrations as high as $4,990 \mathrm{mg} / \mathrm{L}$.

The collective lateral extent of possible moderately contaminated water in the shallow aquifers is $3.7 \mathrm{mi}^{2}$ (areas shaded pale yellow in fig. 14). These areas are delineated by moderate apparent conductivity, but do not contain water wells for confirmation by analysis of water samples. At least 30 moderately contaminated plumes are possible, and vary in extent from $<0.01 \mathrm{mi}^{2}$ (in several locations throughout study area) to $0.5 \mathrm{mi}^{2}$ (in southwest corner of study area).

The collective lateral extent of confirmed considerably contaminated water in the shallow aquifers is $1.7 \mathrm{mi}^{2}$ (areas shaded dark pink in fig. 14). Two confirmed considerably contaminated plumes are located in terrace 3 and have areas of $0.5 \mathrm{mi}^{2}$ and $0.7 \mathrm{mi}^{2}$. Water from more than 20 monitoring wells completed at various depths in these two plumes was considerably contaminated and contained chloride concentrations as high as $44,300 \mathrm{mg} / \mathrm{L}$. More than 10 considerably contaminated plumes are confirmed in the ancestral and modern Poplar River valleys and these plumes vary in extent from $<0.01$ to $0.1 \mathrm{mi}^{2}$.

The collective lateral extent of possible considerably contaminated water in the shallow aquifers is $2.1 \mathrm{mi}^{2}$ (areas shaded pale pink in fig. 14). These areas are delineated by high apparent conductivity, but do not contain water wells for confirmation by analysis of water samples. More than 30 considerably contaminated plumes are possible and vary in extent from $0.01 \mathrm{mi}^{2}$ to $0.3 \mathrm{mi}^{2}$ (terrace 3 ).

\section{Vertical Extent}

The vertical extent of brine contamination in the shallow aquifers can be estimated using apparent conductivity and differential depth calculations (Huang and Fraser, 1996) along the 2004 airborne electromagnetic survey flight lines and using water-quality information from the monitoring and privately owned wells completed in the plumes. Apparent conductivity and associated differential depth computed from the 2004 airborne electromagnetic survey (Smith and others, 2006a) was plotted as conductivity depth sections using the inversion method for much of the surveyed area (Condor Consulting, Inc., 2007). These conductivity depth sections vertically display areas of high and low conductivity that can be compared to water-quality information from water wells to confirm vertical extent of contamination. The depth of investigation is the differential depth at 400 hertz, the frequency with the deepest differential depth (table 2). The depth of investigation is shallower in conductive materials and deeper in resistive materials. The difference between the differential depth at 400 hertz and the top of the Bearpaw Shale is shown in figure 8 . Where this difference is positive, the depth of investigation is above the Bearpaw Shale and usually within the shallow aquifers, but can sometimes be above the shallow aquifers in the unsaturated zone. 


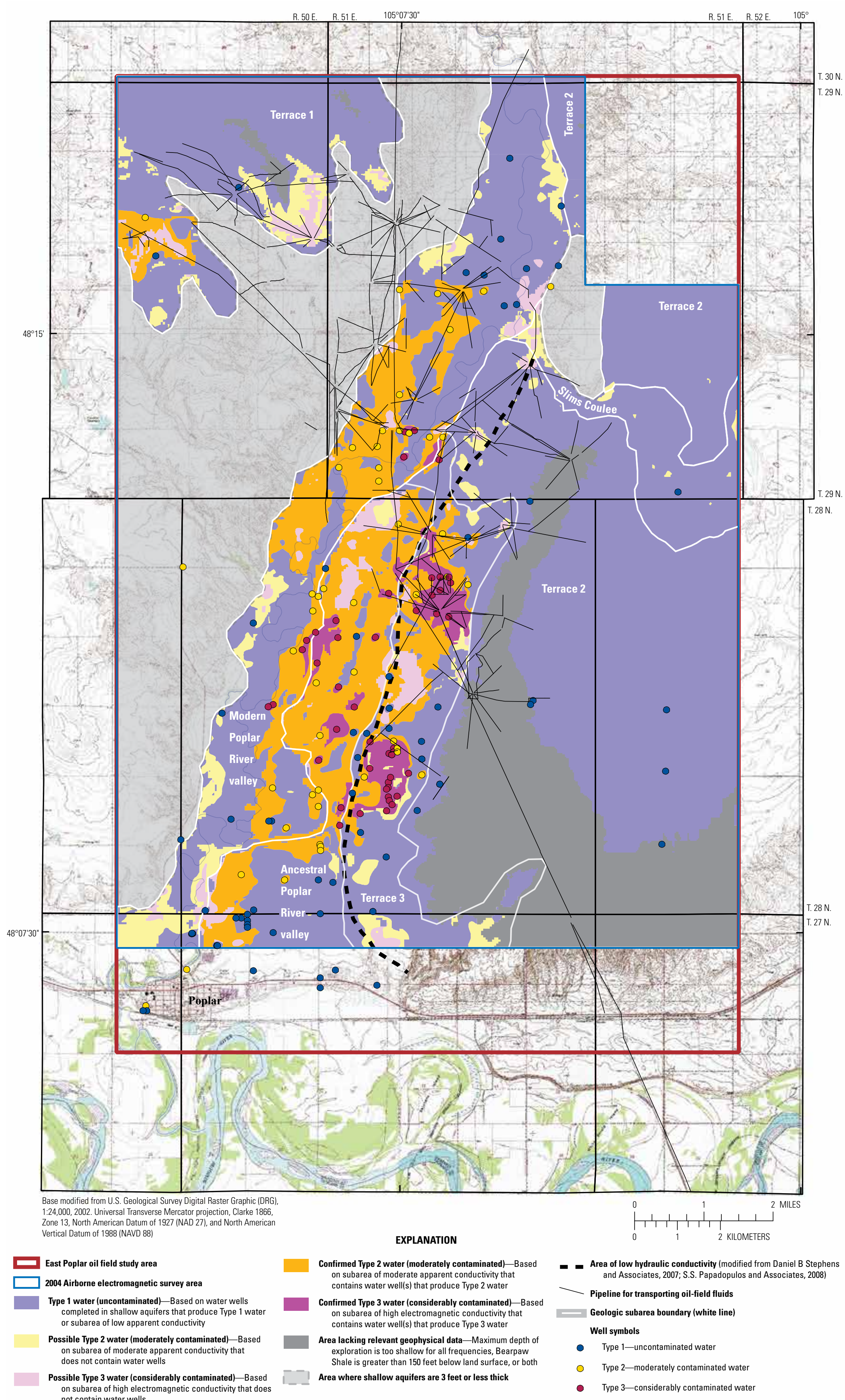

Figure 14. Delineating possible and confirmed areas of brine contamination in shallow aquifers, known pipelines, and types of water in shallow aquifers, in and near the East Poplar 
Possible surface or subsurface sources of brine contamination, time of the source input (recent or old), and distance and migration from the source might be indicated by characteristics of vertical stratification of dissolved-solids and chloride concentrations, density, and conductivity depth sections. Saline water is denser than fresh water and tends to migrate downward with time and distance from its source. Therefore, a recent surface contamination source might be indicated by dense, saline water and high apparent conductivity near the top of the shallow aquifers, whereas an older surface contamination source might be indicated by dense, saline water and high apparent conductivity at various stages of plume migration to lower depths in the shallow aquifers. A subsurface contamination source might be indicated by dense, saline water and high apparent conductivity near the contamination source point(s), either at the bottom of the aquifers or in locations throughout the aquifers. Subsurface sources of brine within the shallow aquifers might result in greater salinity and conductivity at depth with fresh water and lower conductivity near the surface. Likewise, a long-term surface or shallow subsurface source that is still contributing brine to the shallow aquifers might be indicated by the presence of dense, saline water and high apparent conductivity throughout the aquifers.

The estimated vertical extent of brine contamination in the shallow aquifers is indicated by high apparent conductivities in conductivity depth sections along two flight lines (T19020 and L10390) that cross areas with high density of oilfield activity and contain monitoring wells (fig. 15). Flight line numbers preceded by "T" are oriented along an east-west direction and flight line numbers preceded by " $\mathrm{L}$ " are oriented along a north-south direction. The locations of the conductivity depth sections in figure 15 are shown on the base map as thick solid lines. The map also includes the lateral extent of low, moderate, and high apparent conductivity in shallow aquifers that is delineated in figure 14. Two versions of interpreted sections are provided for each line in figure 15, the differential depth method (Haung and Fraser, 1996) and the inversion method (Condor Consulting, Inc., 2007). General areas of high and low conductivity are similar for depth sections using these methods. The approximate top of the Bearpaw Shale is shown as a brown dotted line in the differential conductivity depth section. The approximate depth of investigation is shown as a black dashed line in the inversion conductivity depth section. Monitoring and privately owned water wells and oil-related features located on or near the respective flight lines are labeled and included in the conductivity depth sections. The differential depth method was used throughout the study area to delineate the lateral extent of brine contamination.

The first example is the conductivity depth section along west-east line T19020 (fig. 15) that delineates the vertical extent of a confirmed considerably contaminated (Type 3 ) plume in terrace 3 east of the Poplar River and the vertical extent of a confirmed moderately contaminated (Type 2) plume in the modern Poplar River valley. The contamination in the terrace is defined by wells USGS93-3, USGS93-3A, PNR-4, PNR-5, PNR-14, PNR-15, PNR-17, PNR-23, PNR-24, PNR-25, and PNR-26 (appendix 5). These wells are completed at depths between 38 and $81 \mathrm{ft}$ (PNR-25 and USGS93-3) below land surface. The conductivity depth section indicates that maximum apparent conductivity near or at $500 \mathrm{mS} / \mathrm{m}$ extends vertically through all of the shallow aquifers (fig. 15) to the top of the Bearpaw Shale. Water sampled during 2004 from wells deeper than $40 \mathrm{ft}$ was considerably contaminated (Type 3). Water sampled from the two shallowest wells PNR-25 (38 ft deep) and PNR-26 (40 ft deep) before 2004 was considerably contaminated (Type 3 ), but during and after 2004 became moderately contaminated (Type 2). The apparent conductivity and water-quality information in this plume indicates that brine contamination is present throughout the entire vertical extent of the shallow aquifers. In addition, the contamination in this plume increases with depth and probably extends into the Bearpaw Shale since anomalously high apparent conductivities occur at differential depth below the top of the Bearpaw Shale. The stratification and migration of contamination present in the upper part of this documented plume (p. 26 in Thamke and Craigg, 1997; p. 9 in CH2M Hill, 2000; Pioneer Natural Resources USA, Inc., 2000; and Friedman, 2009) likely developed after the active subsurface source was plugged during 2001, and water-quality results after 2001 in the shallower wells have decreased substantially (PNR-25 and PNR-26, appendix 5). 

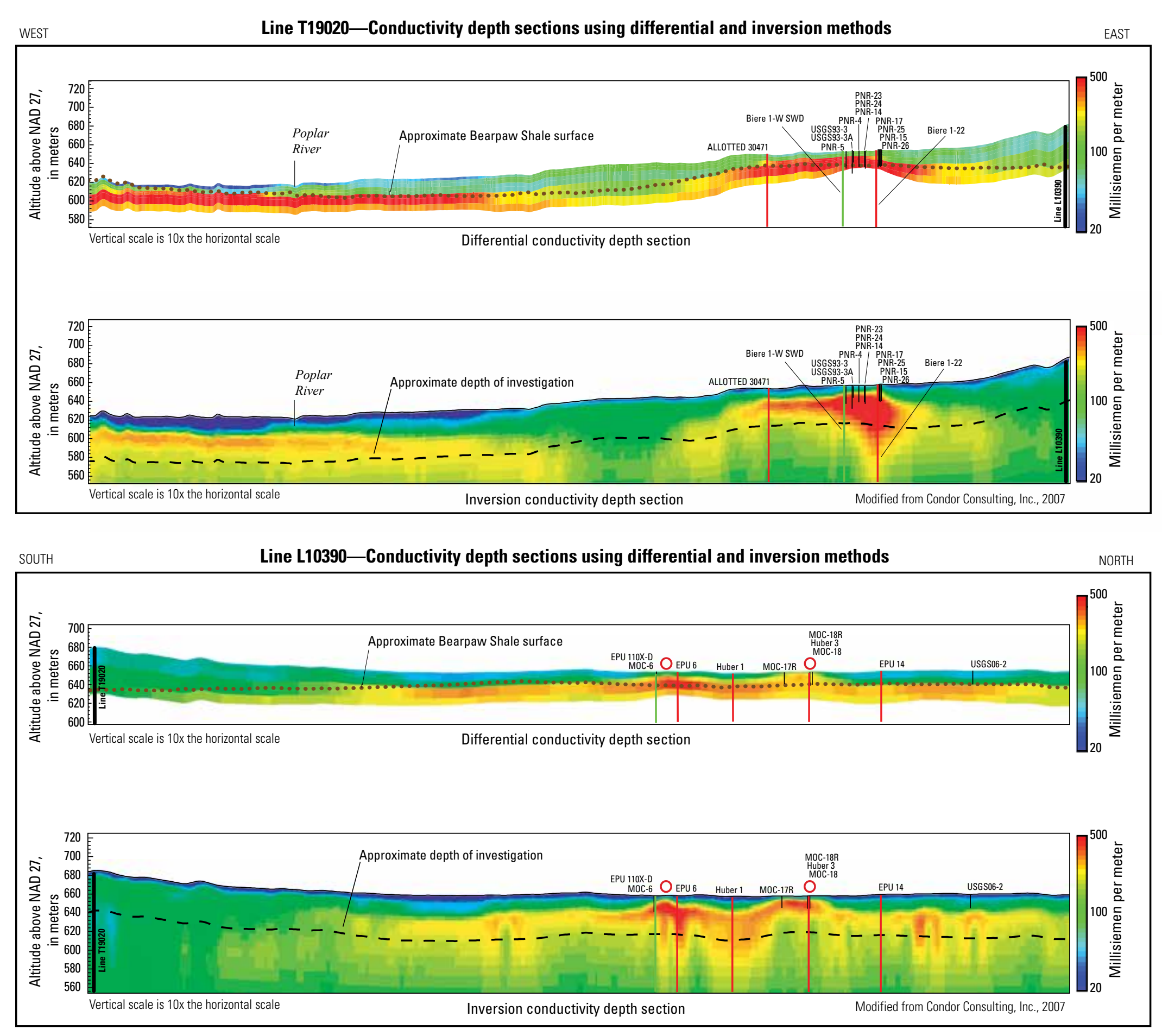

\section{EXPLANATION}

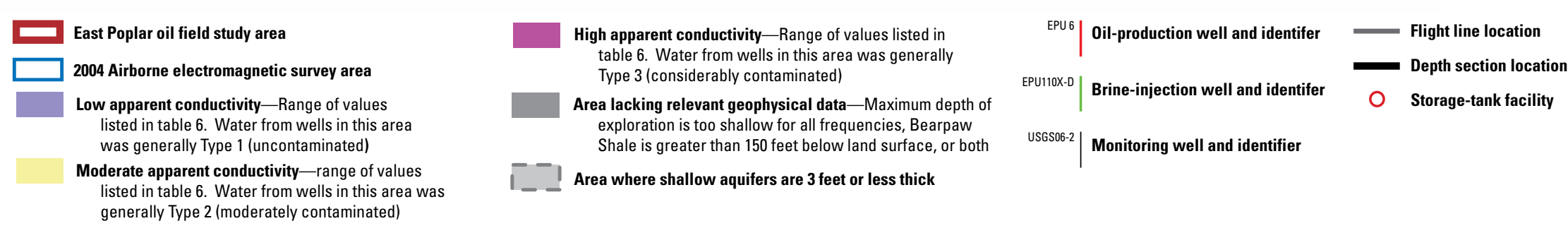

Figure 15. Conductivity depth sections using differential and inversion methods for flight lines L10390 and T19020, in and near the East Poplar oil field, 2004.

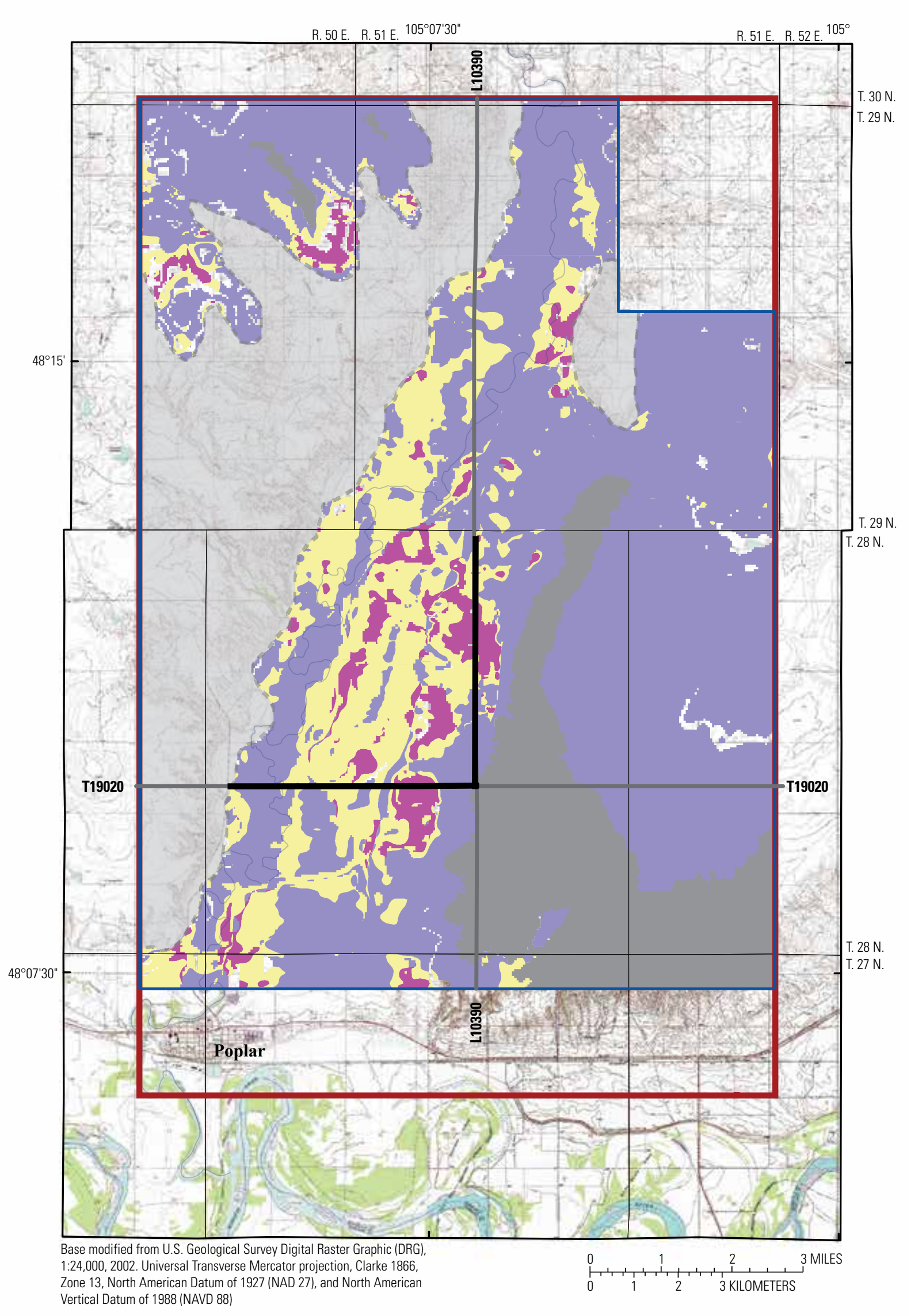


The second example is the conductivity depth section along the northern part of south-north line L10390 (fig. 15) to delineate the vertical extent of confirmed moderately contaminated (Type 2) and confirmed considerably contaminated (Type 3) plumes in terrace 3 east of the Poplar River. These plumes are confirmed by water-quality results in wells MOC6, MOC-7, MOC-10, MOC-13D, MOC-14, MOC-16, MOC17R, MOC-18, MOC-18R, and USGS06-2 (appendix 5). Wells MOC-16 and MOC-6 are completed at depths between 46 and $62 \mathrm{ft}$ below land surface. The depth section indicates that the apparent conductivity generally is above $250 \mathrm{mS} / \mathrm{m}$ vertically throughout most of the contaminated shallow aquifers. In parts of the depth section, high apparent conductivity is near the land surface, sometimes associated with storage-tank facilities (fig. 15). In another part of the depth section, high apparent conductivity extends below the shallow aquifers into the underlying Bearpaw Shale in a vertical pattern adjacent to a production well (EPU 6; fig. 15). In other parts of the depth section, high apparent conductivity extends into the Bearpaw Shale, because the contamination has likely seeped into the weathered top of the shale (fig. 15). None of these monitoring wells were sampled during the same time as the airborne electromagnetic survey in 2004, but nearly all were sampled during 2001-03. Water sampled during 2001-03 from nearly all of the wells was considerably contaminated (Type 3 ) and water sampled from one well (MOC-18) during 2001 was moderately contaminated (Type 2). MOC-18 was replaced by MOC-18R before collecting water samples during 2002 that were considerably contaminated. The apparent conductivity and water-quality information in this plume indicates brine contamination is present throughout the entire vertical extent of the shallow aquifers and that the contamination within the plume is likely larger near potential sources located near the land surface and potential point sources that extend below the shallow aquifers.

\section{Magnitude}

The magnitude of water in the shallow aquifers within the study area possibly affected by brine contamination ranges from about 15 to 37 billion gallons. This volume range is based on calculations of the thicknesses of the shallow aquifers for the delineated lateral extent of confirmed and possible moderately (Type 2) and considerably (Type 3) contamination and the porosity of the shallow aquifers. The volume assumes that the contamination is present throughout the entire thickness of the shallow aquifers. The thickness of the shallow aquifers was calculated as the volume between the configuration of the top of the shallow aquifers (fig. 6) and the configuration of the top of the Bearpaw Shale (fig. 7), which is generally the bottom of the shallow aquifers. The delineation of the confirmed and possible contamination (fig. 14) was used as the lateral extent for the volume calculation. The thickness of the shallow aquifers ranges from 0 to $56 \mathrm{ft}$; the lateral extent of the confirmed and possible contamination plumes is $17.9 \mathrm{mi}^{2}$; and the porosity of gravel, sands, and clays typically present in the shallow aquifers has a range of 20-50 percent (p. 7 in Heath, 1983).

\section{Movement}

Movement of brine contamination in the shallow aquifers can be affected by the presence or absence of sands and gravel in the aquifers and the topography of the Bearpaw Shale underlying the aquifers, and monitored by repeated groundwater sampling through time. The sands and gravel that form the shallow aquifers were deposited fluvially in a typical channelgeometry pattern and likely provide preferential flow paths for groundwater that, if contaminated and has high apparent conductivity, can sometimes be delineated with airborne electromagnetic data. For example, small channels that cross a narrow band of low hydraulic conductivity (fig. 14) can be observed in apparent conductivity maps at 8,200 and 1,800 hertz (Smith and others, 2006a, plate 1). The Wiota Gravel generally is thin or absent along this narrow band and could hinder movement between terrace 3 to the lower elevation in the ancestral Poplar River valley; however, possible and confirmed areas of contamination are present on both sides of the low hydraulic conductivity band (fig. 14) and connect across the band.

Movement of brine contamination in the shallow aquifers also can be affected by the topography of the underlying Bearpaw Shale. The top of the Bearpaw Shale has been incised by the Poplar River into a valley that is lower than the adjacent terrace on the east and the exposed shale on the west (fig. 7). Generalized potentiometric surface and direction of groundwater movement in the shallow aquifers have been determined for several time periods and within several parts of the study area (Thamke and Craigg, 1997, fig. 6; Land and Water Consulting, 2003, figs. 4-5; Daniel B. Stephens \& Associates, Inc., 2007, fig. 2; and S.S. Papadopulos \& Associated, In., 2008, fig. 2). Water in the shallow aquifers generally moves towards the Poplar River and merges with southward-flowing groundwater in the ancestral and modern Poplar River valley towards the Missouri River, ultimately merging with eastward-flowing groundwater in the larger Missouri River valley. Lateral extent of possible and confirmed contamination plumes are lenticular (fig. 14) and generally follow these flow directions.

Movement of brine contamination can be understood by describing changes in groundwater quality. Changes in groundwater quality between 1993 and 2000 are described in Thamke and Midtlyng (2003). Groundwater quality continues to change in parts of the East Poplar oil field study area. The following sets of examples describe substantial changes in groundwater quality that have occurred after 2000 in three parts of the study area. These examples depict changes where upgradient contamination is moving into areas and resulting in increased contamination, where contaminated groundwater is being removed and resulting in decreased contamination, and where contaminated groundwater is moving out of areas and resulting in decreased contamination. 
In the first set of examples, chloride and dissolved-solids concentrations increased between 2000 and 2004 in groundwater within an area about $1 \mathrm{mi}^{2}$ located in the central part of the study area (sec. 09, T. 28 N., R. 51 E.; appendix 5). During 1992-93, this part of the study area was downgradient of a large confirmed Type 3 plume (Area 1 in plate 3, Thamke and Craigg, 1997) and located within several confirmed Type 2 and 3 plumes (Area 2 in plate 3, Thamke and Craigg, 1997). By 2004, this part of the study area was located within a combination of uncontaminated water (Type 1), confirmed moderately contaminated (Type 2) water, and unconfirmed considerably contaminated (Type 3 ) water (fig. 14). Chloride and dissolved-solids concentrations increased as much as $1,796 \mathrm{mg} / \mathrm{L}$ per year and 3,536 mg/L per year in water collected between 2001 and 2003 from monitoring well MOC-11. Similar water-quality conditions and changes occurred through 2004 in water from wells M-14, M-15, and USGS93-5 (appendix 5). Chloride and dissolved-solids concentrations probably increased through 2004 because upgradient brine contamination was moving into shallow aquifers near these wells (p. 25 in Thamke and Craigg, 1997; p. 8 in Thamke and Midtlyng, 2003).

In the second set of examples, chloride and dissolvedsolids concentrations increased between 2001 and 2009 in groundwater within an area $>1 \mathrm{mi}^{2}$ located in the south-central part of the study area (secs. 21, 22, 27, and 28,T. 28 N., R51 E.; appendix 5). During 1992-93, this part of the study area was within a confirmed Type 3 plume (Area 2 of plate 3 in Thamke and Craigg, 1997). During 2004, this part of the study area was still within a confirmed considerably contaminated (Type 3) plume (fig. 14). Chloride and dissolved-solids concentrations increased as much as $6,300 \mathrm{mg} / \mathrm{L}$ (average annual rate of $777 \mathrm{mg} / \mathrm{L}$ chloride) and $10,400 \mathrm{mg} / \mathrm{L}$ (average annual rate of $1,274 \mathrm{mg} / \mathrm{L}$ dissolved solids) in water collected between 2001 and 2009 from monitoring well PNR-20 (appendix 5). Similar water-quality conditions and changes occurred through 2008 in water from wells PNR-8, PNR-18, PNR-19, PNR-22, PNR-27, PNR-28, PNR-34-07 and PNR-39-08 (appendix 5). During 2001, these wells were located within and near a confirmed considerably contaminated (Type 3 ) plume that contained at least one active source of contamination (p. 26 in Thamke and Craigg, 1997; p. 9 in CH2M Hill, 2000). In 2001, an oil-production well within the Type 3 confirmed plume, Biere 1-22 (Pioneer Natural Resources USA, Inc., 2000), was sealed. In late 2008, a system of wells in this part of the study area began removing water from the shallow aquifers and injecting to a deep $(7,600 \mathrm{ft})$ well completed in the Devonian Nisku Formation (Friedman, 2009). After 2008, chloride or dissolved-solids concentrations, or both, decreased in monitoring wells PNR-8, PNR-19, and PNR-22 because of nearby pumped wells.

In the third set of examples, chloride and dissolved-solids concentrations decreased between the early 2000s and 2009 in groundwater within an area about $2 \mathrm{mi}^{2}$ near the Poplar River valley in the central part of the study area (secs. 31 and 32, T. 29 N, R. 51 E.; appendix 5). Concerns about groundwater contamination in this area were documented as early as 1957 (S.L. Groff, MBMG, written commun.,1957 and 1961) and subsequently documented using data collected during 1975-79 (Fish, 1979) and 1979-82 (Levings, 1984). During 1992-93, this part of the study area was within a confirmed considerably contaminated (Type 3) plume (Area 1 in plate 3, Thamke and Craigg, 1997) and was identified as an example of decreasing contamination since the early 1980s (p. 26 in Thamke and Craigg, 1997; p. 12 in Thamke and Midtlyng, 2000). Chloride and dissolved-solids concentrations continued to decrease in water collected after 2000 from wells USGS82-11, USGS926, USGS92-10, USGS92-9, USGS92-7, USGS92-4, and USGS92-8 (appendix 5). Saline groundwater in this area from the early 1980s probably has become diluted by fresh water and is moving downgradient towards the Poplar River whereas upgradient saline-water sources likely have diminished or terminated (p. 26 in Thamke and Craigg, 1997). The third set of examples demonstrate how plumes have likely migrated beyond an immediate source area and mixed together in the modern and ancestral Poplar River valley subareas.

\section{Sources}

The source of brine contamination in and near the East Poplar oil field is brine produced with crude oil (p. 31 in Thamke and Craigg, 1997). Water-quality data that includes analyses of strontium isotopes were used to determine that brine-contaminated water in the shallow aquifers in and near the East Poplar oil field has similar isotopic composition to brine produced from the Madison Formation in the Williston Basin, which currently (2014) is the principal oil-producing formation in the East Poplar oil field (Peterman and others, 2010). Specific source areas of brine within the East Poplar oil field can be determined from the apparent conductivity data.

The correlation is strong between areas of significantly high apparent conductivity and the location of likely sources such as brine-injection wells, oil wells, evaporation pits, pipelines, and storage-tank facilities (fig. 16). The apparent conductivity is considered to be significantly high if the value is $70 \mathrm{mS} / \mathrm{m}$ higher (table 6) than the apparent conductivity used to delineate areas of high apparent conductivity in figure 12 . Generally, it is not possible to identify single oil-related features as likely sources of plumes, because several features commonly are co-located.

Sources of brine contamination might exist beyond the correlation of significantly high apparent conductivity. Probable sources might be located hydraulically upgradient of these mapped areas of significantly high apparent conductivities. The areas of high apparent conductivity might not be all inclusive and other specific source areas might exist. Not all oil-production-related features are related to areas of high apparent conductivity. In addition, small point sources may be smaller than can be detected by the airborne electromagnetic survey, have produced lower variations in apparent conductivity, or be located between flight lines. 


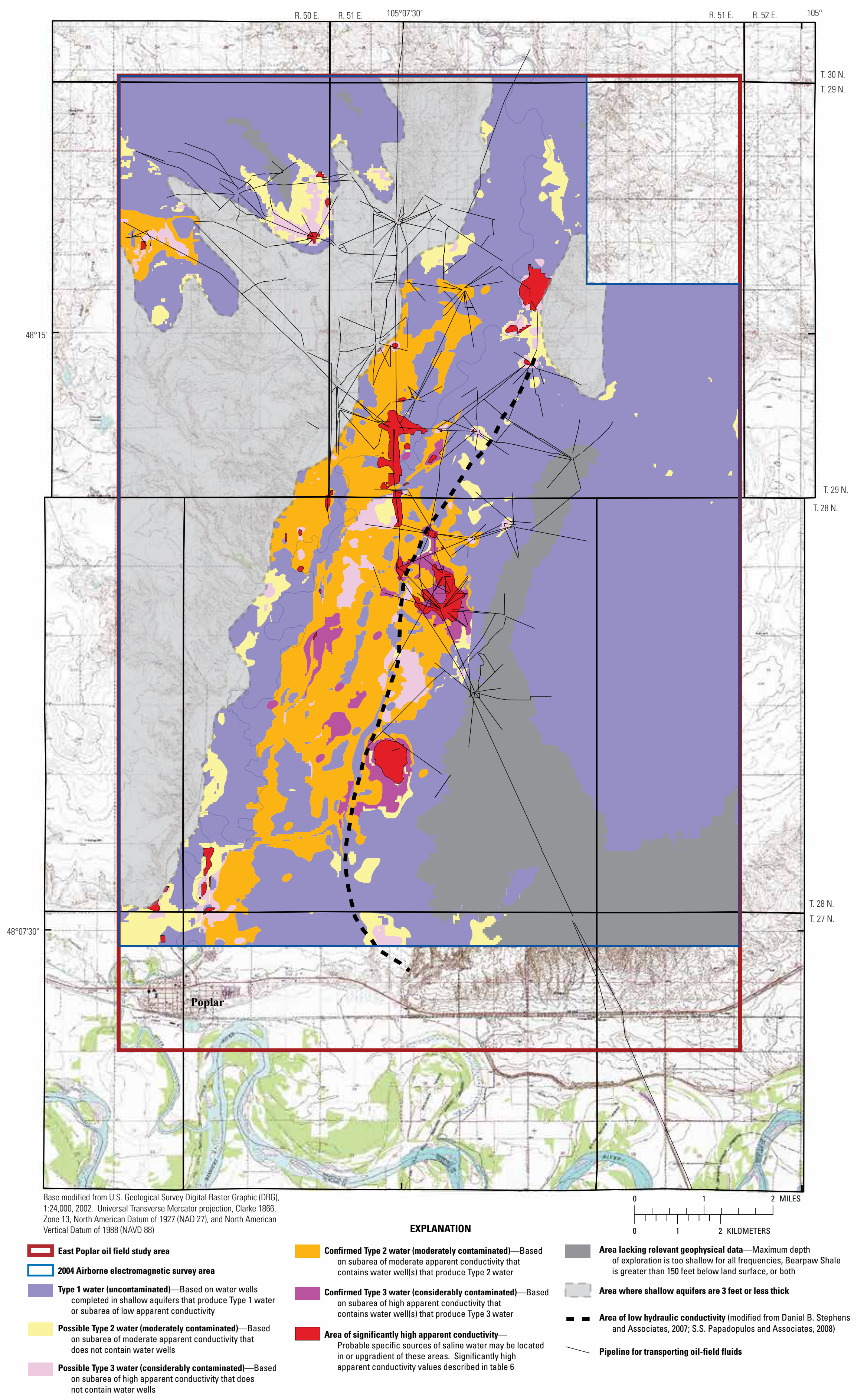

Figure 16. Possible and confirmed areas of brine contamination in shallow aquifers, known pipelines, and probable source areas, 2000-09, in and near the East Poplar oil field. 


\section{Summary}

The shallow aquifers are the only available source of potable groundwater for about 3,000 residents in and near the East Poplar oil field. The city of Poplar public water-supply wells are completed in the shallow aquifers, are located downgradient from brine plumes, and yield water that is enriched in constituents that are present in oil-field brines. The shallow aquifers primarily consist of Quaternary alluvium and the Wiota Gravel with variable sands and gravel, and often have channelized characteristics that likely provide preferential flow paths for groundwater. Water in the shallow aquifers generally moves towards the Poplar River where it merges with southward-flowing groundwater in the Poplar River valley towards the Missouri River, ultimately merging with eastward-flowing groundwater in the larger Missouri River valley. The shallow aquifers are underlain directly by the thick and impermeable Bearpaw Shale, which limits water movement between the shallow aquifers and the deep aquifers beneath the Bearpaw Shale. The shallow aquifers are absent along the western part and in the northeastern corner of the study area where the Bearpaw Shale is very near or at the land surface. The shallow aquifers also are thin or absent along a narrow band that parallels the eastern valley of the ancestral Poplar River; however, minor gravel channels likely cross this band and hydraulically connect the Wiota Gravel in terrace 3 and the ancestral Poplar River valley.

The quality of water in the shallow aquifers in the study area is highly variable and is dependent on location relative to sources of brine contamination. Three types of water exist in the shallow aquifers, and a fourth type of water represents the brine. Type 1 is uncontaminated water that is suitable for most domestic purposes and typically contains sodium bicarbonate and sodium/magnesium sulfate as the dominant ions. Type 2 is moderately contaminated water that is suitable for some domestic purposes, but not used for drinking water, and mostly is sodium chloride. Type 3 is considerably contaminated water that is unsuitable for any domestic purpose and is sodium chloride. Type 3 quality of water in the shallow aquifers is similar to Type 4, which is the brine that is produced with the crude oil.

Apparent conductivity data, collected during 2004 in a 106 square-mile area, correlate well with groundwater quality, collected through 2009. The data were contoured and interpreted in conjunction with water-quality data to delineate the lateral extent of brine plumes in the shallow aquifers during 2004-09. The estimated lateral extent of brine contamination is as much as 17.9 square miles. Water-quality data confirm the presence of 12.1 square miles of contamination, as much as 1.7 square miles of which is considerably contaminated. Apparent conductivity data for unsampled areas indicate 5.8 square miles of possible contamination, 2.1 square miles of which might be considerably contaminated.

In brine-contaminated areas, saline water is present throughout the entire vertical extent of the saturated shallow aquifers, as evidenced by analysis of conductivity depth sections based on differential depths and apparent conductivity along two electromagnetic survey flight lines and analysis of water samples from nested wells at a selected site. At one of the sites located along the depth section, the intensity of contamination increases with depth after an active subsurface source was plugged during 2001. At another site, the intensity of contamination is greatest near potential surface point sources.

About 15 to 37 billion gallons of water in the shallow aquifers possibly are affected by brine contamination. This estimate is based on a range of porosity for the shallow aquifers and estimated thickness of the shallow aquifers where confirmed and possibly contaminated areas have been delineated.

Generally, brine contamination moves laterally in the direction of groundwater flow-laterally toward the Poplar River then merges with groundwater in the Poplar River valley and moves southward in the Poplar River valley. The movement of brine plumes is evidenced by the changes in water-quality with time. In two examples, chloride and dissolved-solids concentrations increased in water from wells as upgradient brine contamination moved into the shallow aquifers at the well locations. In one example, chloride and dissolved-solids concentrations decreased in water from wells as upgradient fresh water moved into the area of contamination near the wells.

The source of brine contamination in the shallow aquifers is brine produced with crude oil in the East Poplar oil field study area. Within the brine contamination plumes, the locations of significantly high apparent conductivity values generally are close to the locations of particular storage-tank facilities, oil wells, brine-injection wells, pipelines, and pits. Generally, it is not possible to identify single oil-related features as likely sources of plumes, because several features commonly are co-located. During the previous 50 years, many brine plumes migrated beyond the immediate source area and likely mix together in the modern and ancestral Poplar River valley subareas.

\section{References Cited}

Bureau of Land Management, 2007, Fort Peck Tribes direct current resistivity survey results: National Science and Technology Center, Bureau of Land Management, plate 1.

Boulton, N.S., 1963, Analysis of data from non-equilibrium pumping tests allowing for delayed yield from storage, in Institution of Civil Engineers, London, 1963, Proceedings: London, England, Institution of Civil Engineers, v. 26, no. 3, p. 469-482.

Brunson, Tim, 1985, Poplar East Field, in Tonnsen, J.J., ed., Montana oil and gas fields symposium, volume 2: Billings, Montana Geological Society, p. 889-891. 
CH2M Hill, 2000, Field investigation Biere well evaluation, Poplar, Montana: Boise, Idaho, prepared for Pioneer Natural Resources, [variously paged].

Colton, R.B., 1963a, Geologic map of the Hay Creek quadrangle, Roosevelt County, Montana: U.S. Geological Survey Geologic Investigations Map I-365, 1 sheet, scale 1:62,500, http://pubs.usgs.gov/imap/0365/plate-1.pdf.

Colton, R.B., 1963b, Geologic map of the Poplar quadrangle, Roosevelt, Richland, and McCone Counties, Montana: U.S. Geological Survey Miscellaneous Geologic Investigations Map I-367, 1 sheet, scale 1:62,500, http://pubs.usgs.gov/ imap/0367/plate-1.pdf.

Condor Consulting, Inc., 2007, Report on processing resolve airborne EM data, East Poplar Project, Roosevelt County, Montana, for Pioneer Natural Resources USA, Inc: Lakewood, Colorado, Condor Consulting, [variously paged].

Dane, J.H., and Topp, G.C., eds., 2002, Methods of soil analysis, Part 4, Physical Methods: Madison, Wisconsin, Soil Science of America Book Series, v. 5, 1,692 p.

Daniel B. Stephens \& Associates, Inc., 2007, Groundwater modeling for Biere well brine plume remediation system design: Albuquerque, New Mexico, [variously paged].

Dionex, 2001, Determination of inorganic anions in wastewater by ion chromatography: Dionex Application Note 135, 11 p., available at: www.dionex.com/en-us/ webdocs/4085-AN135_LPN1226-01.pdf

Dodge, K.A., Hornberger, M.I., and Dyke, J.L., 2009, Waterquality, bed-sediment, and biological data (October 2007 through September 2008) and statistical summaries of longterm data for streams in the Clark Fork basin, Montana: U.S. Geological Survey Open-File Report 2009-1178, 139 p., http://pubs.usgs.gov/of/2009/1178/.

Fish, A.R., 1979, East Poplar field area, O.A. Lien Complaint, Roosevelt County, Montana: Montana Department of Natural Resources and Conservation, $12 \mathrm{p}$.

Freeze, R. Allan, and Cherry, John A., 1979, Groundwater: Englewood Cliffs, New Jersey, Prentice-Hall, Inc., 604 p.

Friedman, Barry, 2009, Project changed the environment: American Association of Petroleum Geologists Explorer, available at $h t t p: / / w w w . a a p g . o r g / e x p l o r e r / 2009 / 06 j u n /$ fortpeck0609.cfm.

Healy, R.W., Rice, C.A., Bartos, T.T., and McKinley, M.P., 2008, Infiltration from an impoundment for coal-bed natural gas, Powder River Basin, Wyoming: Evolution of water and sediment chemistry: Water Resources Research, v. 44, W06424, doi: 10.1029/2007WR006396.

Heath, R.C., 1983, Basic ground-water hydrology: U.S. Geological Survey Water-Supply Paper 2220, 84 p., http://pubs.usgs.gov/wsp/2220/report.pdf.
Hem, J.D., 1985, Study and interpretation of the chemical characteristics of natural water (3d ed.): U.S. Geological Survey Water-Supply Paper 2254, 263 p., http://pubs.usgs. gov/wsp/wsp2254/.

HKM Engineering, Inc., 2007a, Aquifer characterization study Biere I-22 well site, Roosevelt County, Poplar, Montana: Bozeman, Mont., prepared for Pioneer Natural Resources USA, Inc., [variously paged].

HKM Engineering, Inc., 2007b, Aquifer characterization study No. 2 Biere I-22 well site, (February, 2007 slug testing), Roosevelt County, Poplar, Montana: Bozeman, Mont., prepared for Pioneer Natural Resources USA, Inc., [variously paged].

HKM Engineering, Inc., 2007c, Aquifer characterization study No. 3 Biere I-22 well site (March, 2007 slug testing), Roosevelt County, Poplar, Montana: Bozeman, Mont., prepared for Pioneer Natural Resources USA, Inc., [variously paged].

Huang, H., and Fraser, D.C., 1996, The differential parameter method for multifrequency airborne resistivity mapping: Geophysics, v. 61, p. 100-109

Keys, W.S., 1989, Borehole geophysics applied to groundwater investigations: Dublin, Ohio, National Water Well Association, $313 \mathrm{p}$.

Lambing, J.H., comp., 2006, Quality-assurance plan for water-quality activities of the U.S. Geological Survey Montana Water Science Center: U.S. Geological Survey Open-File Report 2006-1275, 39 p., http://pubs.usgs.gov/ of/2006/1275/.

Land and Water Consulting, Inc., 2003, Public water supply well threat study, East Poplar oil field, Roosevelt County, Montana: Missoula, Mont., prepared for Murphy Exploration and Production Company, Pioneer Natural Resources, Marathon Ashland Petroleum, and Samson, [variously paged].

Levings, G.W., 1984, Reconnaissance evaluation of contamination in the alluvial aquifer in the East Poplar oil field, Roosevelt County, Montana: U.S. Geological Survey Water-Resources Investigations Report 84-4174, 29 p., http://pubs.usgs.gov/wri/1984/4174/report.pdf.

Lohman, S.W., 1979, Ground-Water Hydraulics: U.S. Geological Survey Professional Paper 708, 70 p., http://pubs.usgs.gov/pp/0708/report.pdf.

McMahon, P.B., Dennehy, K.F., Michel, R.L., Sophocleous, M.A., Ellet, K.M., and Hurlbut, D.B., 2003, Water movement through thick unsaturated zones overlying the central High Plains aquifer, southwestern Kansas, 2000-2001: U.S. Geological Survey Water-Resources Investigations Report 2003-4171, 32 p., http://pubs.usgs. gov/wri/wrir03-4171/. 
Montana Board of Oil and Gas Conservation, 2005, MBOGC's Online Oil and Gas Information System: accessed January 10, 2005, at http://bogc.dnrc.mt.gov/.

Montana Bureau of Mines and Geology, 2010, Ground-water information center (GWIC): Montana Bureau of Mines and Geology database, accessed February 22, 2010, at http://mbmggwic.mtech.edu/

Montana Department of Environmental Quality, 2002, Source water delineation and assessment report, City of Poplar: Helena, Mont., PWSID \#00310, 39 p.

McNeill, J.D., 1979, Operating Manual for EM34-3: Mississauga, Ontario, Geonics Ltd., 28 p.

McNeill, J.D., 1980, Electrical conductivity of soils and rocks: Mississauga, Ontario, Geonics Ltd., Technical Note TN-5 $22 \mathrm{p}$.

McNeill, J.D., 1983, EM34-3 survey interpretation techniques: Mississauga, Ontario, Geonics Ltd., Technical Note TN-8, $17 \mathrm{p}$.

Mount Sopris Instruments Company Ltd., 2002a, MSLog v.7 for the MGX II operators manual: Denver, Colorado, Mount Sopris, $78 \mathrm{p}$.

Mount Sopris Instruments Company Ltd., 2002b, 2PIA-1000 Poly induction probe manual: Denver, Colorado, Mount Sopris, $11 \mathrm{p}$.

Mount Sopris Instruments Company Ltd., 2002c, 2PGA-1000 Poly gamma probe manual: Denver, Colorado, Mount Sopris, $10 \mathrm{p}$.

Peterman, Zell E., Thamke, Joanna N., Futa, Kiyoto, and Oliver, Thomas A., 2010, Strontium isotope detection of brine contamination in the East Poplar oil field, Montana: U.S. Geological Survey Scientific Investigations Report 2010-1326, 20 p., http://pubs.usgs.gov/of/2010/1326/.

Pioneer Natural Resources USA, Inc., 2000, Proposed Biere 1-22 Well Response Action Plan: Irving, Texas [variously paged].

S.S. Papadopulos \& Associates, Inc., 2007, Phase 1 report, Collecting and evaluating current and historic site information: Boulder, Colo., [variously paged].

S.S. Papadopulos \& Associates, Inc., 2008, Phase 2 report, Hydrogeologic assessment of chloride-migration potential in the vicinity of Poplar, Montana: Boulder, Colo., prepared for Fort Peck Assiniboine \& Sioux Tribes, [variously paged].

Scanlon, B.R., Healy, R.W., and Cook, P.G., 2002, Choosing appropriate techniques for quantifying groundwater recharge: Hydrogeology Journal, v. 10, no. 1, p. 18-39.
Scanlon, B.R., Stonestrom, D.A., Reedy, R.C., Leaney, F.W., Gates, J., and Cresswell, R.G., 2009, Inventories and mobilization of unsaturated zone sulfate, fluoride, and chloride related to land use change in semiarid regions, southwestern United States and Australia: Water Resources Research, v. 45, no. 7, W00A18, doi: 10.1029/2008WR006963.

Siemon, B., 2006. Electromagnetic methods-Frequency domain, airborne techniques, in Kirsch, R., ed., Groundwater geophysics - A tool for hydrogeology: Berlin, Springer, p. 155-178.

Smith, B.D., Irvine, R., Blome, C.D., Clark, A.K., and Smith, D.V., 2003, Preliminary results, helicopter electromagnetic and magnetic survey of the Seco Creek area, Medina and Uvalde Counties, Texas, in Symposium on the Application of Geophysics to Environmental and Engineering Problems, San Antonio, Texas, 2003, Proceedings: San Antonio, Texas, Annual Meeting of Environmental and Engineering Society, $13 \mathrm{p}$.

Smith, B.D., Thamke, J.N., Cain, M.J., Tyrrell, C., and Hill, P.L., 2006a, Helicopter electromagnetic and magnetic survey maps and data, East Poplar Oil Field area, August 2004, Fort Peck Indian Reservation, northeastern Montana: U.S. Geological Survey Open-File Report, 2006-1216, 18 p., http://pubs.usgs.gov/of/2006/1216/.

Smith, B.D., Thamke, J.N., and Tyrrell, C., 2006b, Geophysical and hydrologic studies of shallow aquifer contamination, East Poplar Oil Field area, and northeastern Montana, in Symposium on the Application of Geophysics to Environmental and Engineering Problems, Seattle, Wash., 2006, Proceedings: Seattle, Wash., Annual Meeting of Engineering and Environmental Geophysics, 16 p.

Smith, B.D., Thamke, J.N, and Tyrrell, Christa, 2014, Borehole geophysical data for the East Poplar oil field area, Fort Peck Indian Reservation, northeastern Montana, 1993, 2004, and 2005: U.S. Geological Survey Open-File Report 2013-1288, 11 p., http://dx.doi.org/10.3133/ofr20131288.

Taylor, J.K., 1987, Quality assurance of chemical measurements: Chelsea, Mich., Lewis Publishers, 328 p.

Thamke, J.N., and Craigg, S.D., 1997, Saline-water contamination in Quaternary deposits and the Poplar River, East Poplar oil field, northeastern Montana: U.S. Geological Survey Water-Resources Investigations Report 97-4000, 37 p., http://pubs.er.usgs.gov/publication/wri974000.

Thamke, J.N., Craigg, S.D., and Mendes, T.M., 1996, Hydrologic data for the East Poplar oil field, Fort Peck Indian Reservation, northeastern Montana: U.S. Geological Survey Open-File Report 95-749, 92 p., http://pubs.er.usgs. gov/publication/ofr 95749 . 
Thamke, J.N., and Midtlyng, K.S., 2003, Ground-water quality for two areas in the Fort Peck Indian Reservation, northeastern Montana: U.S. Geological Survey WaterResources Investigations Report 03-4214, 54 p., http://pubs.er.usgs.gov/publication/wri034214.

U.S. Geological Survey, 2008, National Elevation Dataset: accessed on January 15, 2008, at http://ned.usgs.gov/.
U.S. Geological Survey, 2010, National Water Information System (NWISWeb): U.S. Geological Survey database, accessed February 22, 2010, at http://waterdata.usgs.gov/ nwis.

Publishing support provided by:

Rolla and Lafayette Publishing Service Centers

For more information concerning this publication, contact:

Director, USGS Wyoming-Montana Water Science Center

3162 Bozeman Avenue

Helena, MT 59601

(406) 457-5900

Or visit the Wyoming-Montana Water Science Center Web site at: http://wy-mt.water.usgs.gov/ 


\section{$\frac{\mathbb{3}}{\mathrm{C}}$}

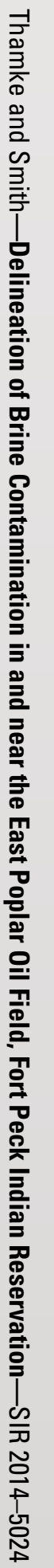

